МИНИСТЕРСТВО ОБРАЗОВАНИЯ И НАУКИ РФ

ФЕДЕРАЛЬНОЕ ГОСУДАРСТВЕННОЕ БЮДЖЕТНОЕ

ОБРАЗОВАТЕЛЬНОЕ УЧРЕЖДЕНИЕ

ВЫСШЕГО ПРОФЕССИОНАЛЬНОГО ОБРАЗОВАНИЯ

"АДЫГЕЙСКИЙ ГОСУДАРСТВЕННЫЙ УНИВЕРСИТЕТ"

\author{
С.А.ХАЗОВА, Ф.Р.ХАТИТ
}
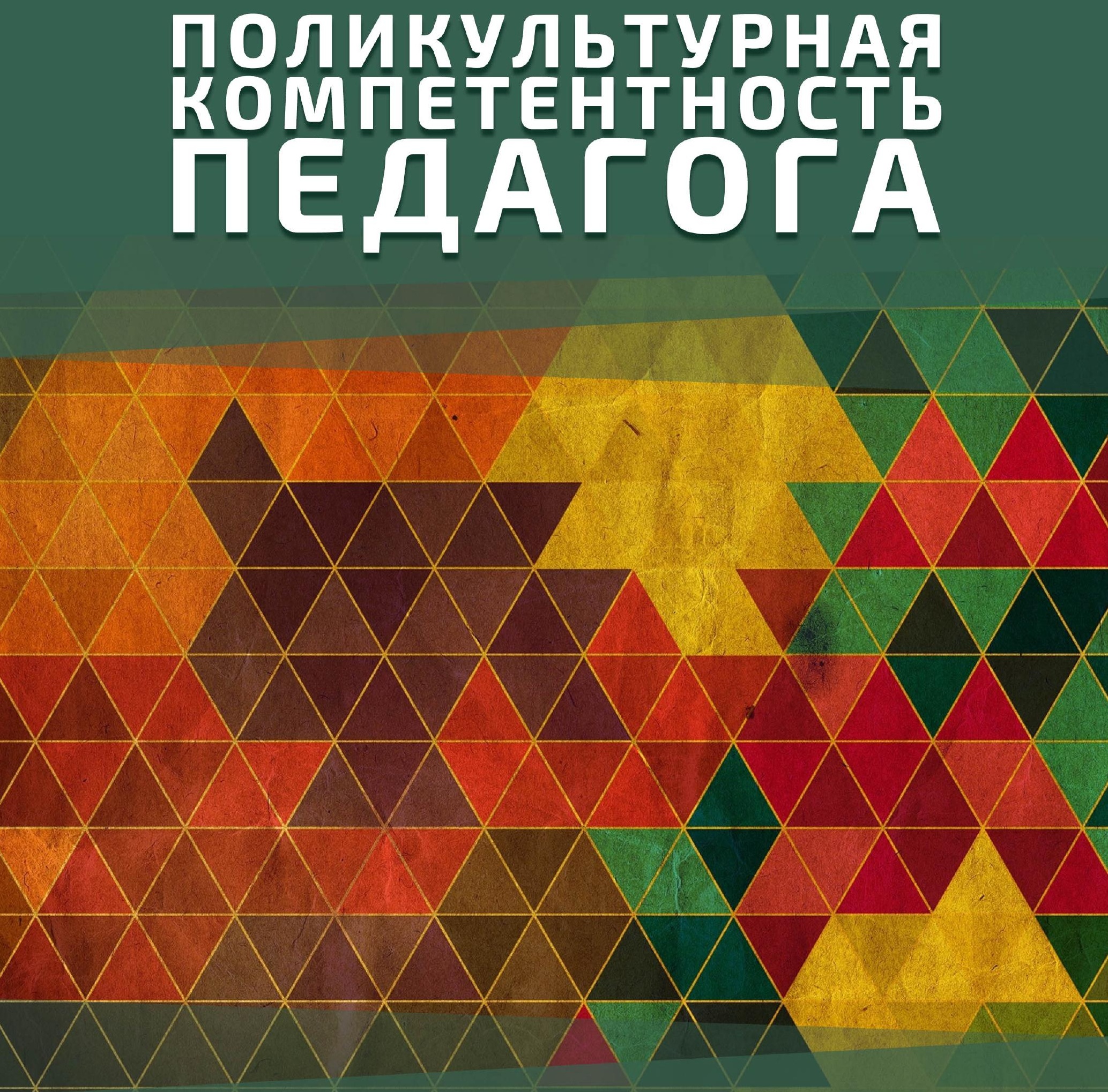

Майкоп 
УДК 373

ББК 74.204 .2

X15

\title{
Хазова, С.A.
}

Поликультурная компетентность педагога: монография. [Электронный ресурс]: научное электронное издание (монография) / С.А. Хазова, Ф.Р. Хатит - Электрон. дан. (2 Мб). - Майкоп: ЭлИТ, 2015. - 1 электрон. опт. диск (CD-R). ISBN 978-5-9906912-5-4. То же [Электронный ресурс]. - Режим доступа: http://www.dx.doi.org/10.18411/2015-11-014. doi: 10.18411/2015-11-014.

\section{РЕЦЕНЗЕНТЫ:}

доктор педагогических наук, профессор

Бегидова С.H.

доктор педагогических наук, профессор

Хакунова Ф.П.

В монографии представлен обобщенный материал о сущуноти $и$ содержании поликультурной компетентности педагога как социиальнои профессионально-значимого личностного качества. Обосновано ее содержание и структурные компоненты, критерии оценки $и$ характеристики уровней сформированности поликультурной компетентности у студентов - будущзих педагогов. Описана совокупность психолого-педагогических условий формирования поликультурной компетентности будущзих педагогов. Представлена методика диагностики и оценки уровня сформированности поликультурной компетентности у будущчих педагогов начального образования.

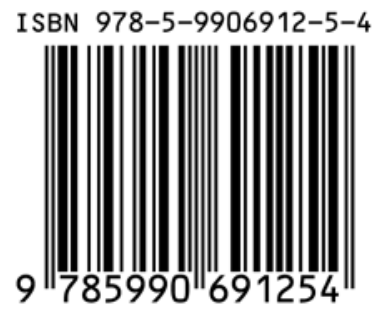

\author{
(C) ФГБОУ ВПО «АГУ», 2015 \\ (C) Хазова С.А., Хатит Ф.Р., 2015 \\ (С Оформление электронного издания ООО «ЭлИТ», 2015
}




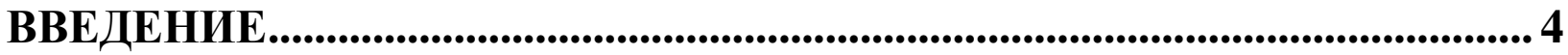

1. ПОЛИКУЛЬТУРНОСТЬ ОБЩЕСТВА И СОДЕРЖАНИЕ ПОЛИКУЛЬТУРНОЙ ПОДГОТОВКИ БУДУЩЕГО ПЕДАГОГА............ 7

2. СУЩНОСТЬ ПОЛИКУЛЬТУРНОЙ КОМПЕТЕНТНОСТИ ПЕДАГОГА.

3. ПСИХОЛОГО-ПЕДАГОГИЧЕСКИЕ УСЛОВИЯ ФОРМИРОВАНИЯ ПОЛИКУЛЬТУРНОЙ КОМПЕТЕНТНОСТИ

БУДУЩИХ ПЕДАГОГОВ

4. КОМПЕТЕНТНОСТНЫЙ ПОДХОД КАК ОСНОВА ОРГАНИЗАЦИИ ПОЛИКУЛЬТУРНОЙ ПОДГОТОВКИ БУДУЩИХ ПЕДАГОГОВ ........ 53

5. ОРГАНИЗАЦИЯ ОБРАЗОВАТЕЛЬНОГО ПРОЦЕССА В ВУЗЕ, НАПРАВЛЕННОГО НА ФОРМИРОВАНИЕ ПОЛИКУЛЬТУРНОЙ КОМПЕТЕНТНОСТИ БУДУЩИХ ПЕДАГОГОВ .

6. ДИАГНОСТИКА И ОЦЕНКА УРОВНЯ СФОРМИРОВАННОСТИ ПОЛИКУЛЬТУРНОЙ КОМПЕТЕНТНОСТИ

БУДУЩИХ ПЕДАГОГОВ .97

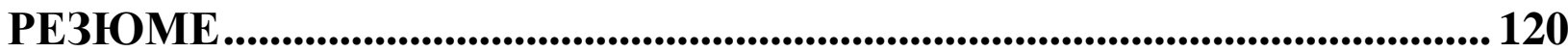

СПИСОК ИСПОЛЬЗОВАННОЙ ЛИТЕРАТУРЫ....................................... 124 


\section{ВВЕДЕНИЕ}

Многие годы в нашей стране господствующая идеология направляла воспитание на унификацию граждан, сведение индивидуально-личностного разнообразия до некоторых усредненных стандартов. Индивидуальные интересы, способности, предпочтения, ценностные ориентации в некоторой степени учитывались в профессиональной ориентации учащихся, но и в данной работе интересам государства отдавалось преимущество: молодежи нередко предлагалось в добровольно-принудительном порядке осваивать конкретные профессии, необходимые в данный момент народному хозяйству. Возможность выделиться из общей массы давала, в некоторой степени, этническая принадлежность человека, однако и в данном аспекте государством официально был объявлен курс на формирование единой нации - советского человека.

С конца XX века в России, как и во всем цивилизованном мире, больше внимания стало уделяться интересам и потребностям личности: признается равноправие личных и общественных интересов, право каждого на собственное мнение, на реализацию индивидуальных способностей и удовлетворение собственных интересов в социальной жизни и профессиональной деятельности, индивидуально-личностный подход к каждому человеку становится основой гуманистической педагогики и т.п. При очевидной гуманности и прогрессивности указанных тенденций, последние имеют ряд следствий, не достаточно учитываемых психологопедагогической наукой: осознав собственную самобытность, каждый человек стремится отстаивать собственное видение мира, собственную правоту, забывая, зачастую, что его окружают такие же индивидуальности. То есть, признавая собственную культурную самобытность, люди не готовы к конструктивному взаимодействию с другими индивидуальными культурами, не готовы к жизни в поликультурном мире, что актуализирует 
поликультурную подготовку, поликультурное образование, поликультурное воспитание и т.п. как важную педагогическую задачу (А.Г.Бермус, И.В.Васютенкова, А.Н.Джуринский, Г.Д.Дмитриев, Е.А.Нечаева, С.М.Федюнина, А.В.Шафрикова, Е.М.Щеглова и др.).

Традиционно поликультурность рассматривается в контексте этнического разнообразия, а поликультурная подготовка граждан сужается до воспитания культуры межнационального общения, толерантности к этнокультурным различиям и т.п. (Г.Д.Дмитриев). Однако некоторые ученые (Г.Д.Дмитриев, Е.М.Щеглова, С.М.Федюнина и др.) справедливо отмечают, что поликультурность общества не сводится только лишь к национальному или религиозному многообразию, а предполагает многообразие жизненных стилей (в основе которых лежат и ценностные ориентации, и установки, и виды деятельности, особенности взаимоотношений и т.д.), характерных для различных социальных групп: этнических и религиозных, возрастных и гендерных, профессиональных и др.

Задача системы образования, таким образом, заключается в подготовке человека к эффективной деятельности и общению в поликультурной среде, что связано с осознанием культурного многообразия, толерантным отношением к этому многообразию и способностью к культуросообразному поведению (в соответствии конкретным культурным условиям) (А.С.Бермус, П.П.Гречко, Т.Ю.Гурьянова, Ж.Делор, Г.Д.Дмитриев, О.В.Еремкина, И.А.Зимняя, Т.Б.Менская, Е.А.Нечаева, Е.М.Щеглова и др.).

Особую важность в этой связи приобретает поликультурная подготовка будущих педагогов, формирование у них поликультурной компетентности и как профессионального, и как общесоциального личностного качества. Такое двустороннее рассмотрение поликультурной компетентности педагога связано, с тем, что учитель, с одной стороны, является членом поликультурного общества, а, с другой - в силу педагогической миссии 
должен быть способен и готов к поликультурному воспитанию подрастающего поколения.

Проблемы поликультурной подготовки относятся к активно исследуемым сегодня научным вопросам и рассматриваются учеными в различных аспектах. Так, поликультурному воспитанию школьников посвящены работы А.Г.Бермуса, А.А.Глебова, А.В.Шафриковой и др. Сравнительный анализ отечественной и зарубежной систем поликультурного воспитания и образования осуществлен А.Н.Джуринским. Содержание поликультурного образования рассматривается Л.М.Бахтиным, А.Ю.Белогуровым, И.В.Васютенковой, Г.Д.Дмитриевым, Т.Б.Менской, М.Н. Певзнером, В.О. Букетовым и О.М. Зайченко и др. Поликультурные аспекты профессиональной подготовки отражены в исследованиях Т.Ю.Гурьяновой, О.В.Еремкиной, Н.А.Лазарева, Е.А.Нечаевой, Н.Н.Руденко и В.Н Руденко и т.д. Вопросы формирования поликультурной компетентности у разных категорий граждан раскрыты в работах Л.Даниловой, И.Л.Плужник, Е.М.Щегловой и т.д. Однако, практически все ученые в данном контексте, во-первых, вопросы поликультурной подготовки раскрывают исключительно в этническом либо этно-религиозном аспектах и, во-вторых, поликультурную компетентность рассматривают либо в социальном, либо в профессиональном ключах. В данной работе поликультурность отражена в многообразии культурных различий, а поликультурная компетентность рассматривается и как общесоциальное, и как профессиональное качество педагога. 


\section{1. ПОЛИКУЛЬТУРНОСТЬ ОБЩЕСТВА И СОДЕРЖАНИЕ ПОЛИКУЛЬТУРНОЙ ПОДГОТОВКИ БУДУЩЕГО ПЕДАГОГА}

Последние десятилетия все большую остроту приобретает обсуждение учеными (социологами, политологами, педагогами, психологами, философами) проблем, обусловленных поликультурным характером современного социума. Большинство исследователей, прежде всего, педагогов, раскрывают данные вопросы в этнокультурном, полиэтническом контексте. На этом основании решение проблем сводится, преимущественно, к воспитанию культуры межнационального общения, воспитанию толерантности относительно этнической либо конфессионной «инаковости». В частности, Г.Д.Дмитриев отмечает, что исследования в области поликультурного образования посвящены, как правило, полиэтническому или многоэтническому образованию, рассматривая таким образом проблему в узком смысле, поскольку последнее отражает важную, но не единственную сторону культуры человечества и не отражает всего ее многообразия [60].

Подобная постановка вопроса, безусловно, оправдана в настоящее время - в период повсеместных социально-интеграционных процессов, с одной стороны, и роста национального самосознания, нередко приводящего к обострению шовинизма, с другой. Однако, на наш взгляд, подготовка граждан к существованию в поликультурном обществе - проблема непреходящая, обусловленная не только национальным и религиозным составом того или иного общества, но и более глубокими, социальнопсихологическими особенностями человека: индивидуальностью каждой личности и ее стремлением сохранять и развивать собственную самобытность, а также потребностью людей «объединяться» не только исторически, по национальному признаку, но и «по интересам», в соответствии с определенными ценностными ориентациями, гендерными и возрастными особенностями, общностью выполняемых профессиональных 
функций, социальных ролей, социального статуса и т.п. Другое дело, что в разные времена (как исторического развития общества, так и онтогенеза человека) те или иные содержательные «пласты» поликультурности приобретают большую выраженность либо для общественного сознания (как, например, национальный контекст в настоящее время), либо для индивидуального сознания определенных групп (возрастной и гендерный поликультуризм для подростков).

Таким образом, поликультурность как свойство социальной реальности - константа, выраженность и степень влияния на общественную жизнь которой, впрочем, зависит от конкретных исторических событий, процессов и явлений. Причем, чем динамичнее ставится жизнь, чем серьезнее, весомее происходящие в обществе изменения, и чем более открытым становится общество, тем очевиднее становятся и многочисленные культурные различия между людьми, не сводимые только лишь к национальным и религиозным различиям.

В частности, сегодня интенсивные интеграционные процессы, «пронизывающие практически все стороны общественной жизни от науки и искусства до экономики и политики, предоставляют возможность соприкоснуться с процессами и явлениями, принадлежащими самым разным культурам» [181, с.5].

Российские граждане оказались не готовыми к такому культурному многообразию. Даже этническое разнообразие, казалась бы, не новое для россиян, становится сегодня причиной многочисленных конфликтов, связанных с непониманием либо нежеланием взаимодействовать с представителями иных национальностей. Повысилось неприятие друг друга лиц, принадлежащий разным социальным группам, людей с разным материальным положением, чрезвычайно обострилась пресловутая проблема «отцов и детей». Таким образом, подготовка к жизнедеятельности в поликультурном обществе, важная во все времена, сегодня особенно 
актуализирована [19,34,47,52,181 и др.]. Особо значима она для будущих педагогов, поскольку они в дальнейшем должны будут в процессе профессиональной деятельности осуществлять и поликультурное воспитание учащихся.

Для выявления теоретических основ поликультурной подготовки студентов - будущих педагогов необходимо, прежде всего, определиться с содержанием ключевого понятия - поликультурности, которое, в свою очередь, определит контекстные образовательные цели и задачи.

Обратимся к родовому понятию - культуре. В своей классификации М.А. Верб приводит интерпретации данного феномена с позиции разных подходов:

- антропологического - культура как противоположность природе, атрибут и результат человеческой деятельности, основное отличие человека от животного и универсальный способ человеческого бытия [33,55,82,148];

- аксиологического (ценностного) - культура как совокупность духовных и материальных ценностей, выработанных людьми и как реализация человеком идеально-ценностных целей $[125,173]$;

- социологический - культура как совокупность общественных отношений, форма общения между людьми [92,93];

- личностно-деятельностного - культура как способ человеческой деятельности, совокупность материальных и духовных предметов человеческой деятельности, духовных процессов, видов деятельности $[53,98,99,138]$;

- интегративного - культура как многостороннее явление, характеризующееся целостной вариативностью, и включающее характерные для определенной группы (социальной, этнической, политической и т.п.) людей ценностные ориентации, традиции, социальные и политические отношения, мировоззрение, систему убеждений, оценок, картин мира, идей и идеологий [74,75 и др.] и др. [38]. 
Для всех трактовок общим является признание культуры атрибутом человека, его сознания и созидательной деятельности. Важным отличием является соотнесение культуры исключительно с определенными содержательными группами ценностей или видов деятельности, характерное для аксиологического и личностно-деятельностного подходов, либо с социальными общностями, группами людей, данные ценности, установки и т.д. создающими и разделяющими (социологический и интегративный подходы). Это отличие ярко проявляется в случае, когда необходимо проанализировать сущность понятия «поликультурность». Интегративный подход в наилучшей степени позволяет охарактеризовать феномен поликультурности, не привязывая его ни к предметным, ни к этническим и религиозным составляющим.

В современных исследованиях существует два принципиально разных подхода к трактовке данного феномена. Одни ученые, характеризуя поликультурность, отправной точкой выбирают предметное содержание самой культуры: информация, духовные ценности, виды деятельности и т.д.; в содержание поликультурности в этом случае включается информационная, коммуникативная, конфликтологическая, художественная, физическая и т.д. культуры; поликультурность характеризует степень полипредметности феномена «культура» $[4,128]$. Поликультурной личностью с данной позиции является личность, освоившая указанное предметное многообразие: владеющая информационной и конфликтологической культурой, культурой общения и т.д.

Признавая правомочность указанной точки зрения, мы будем придерживаться иной позиции, свойственной интегративному подходу, и «отталкиваться» от субъекта культуры - человека. В этом случае во внимание принимаются особенности человека как члена определенной социальной группы, аспекты, по которым он идентифицирует себя в обществе [158]. Поликультурность общества, таким образом, 
характеризуется многообразием этнокультур, религиозных, возрастных и гендерных, профессиональных культур, молодежных субкультур и т.п., а в личностном аспекте - принятием этого разнообразия и способностью эффективно жить и работать в поликультурной среде.

Е.М.Щеглова определяет культуру как «стиль жизни, характерный для каждой социальной группы, который не передается по наследству, а конструируется самими членами этой группы и познается индивидом в процессе образования, самообразования и иного информационного воздействия» [181, с.13]. Таким образом, поликультурность предполагает многообразие жизненных стилей (в основе которых лежат и ценностные ориентации, и установки, и виды деятельности, особенности взаимоотношений и т.д.), характерных для различных социальных групп: этнических и религиозных, возрастных и гендерных, профессиональных и др. Задача системы образования, таким образом, заключается в подготовке человека к эффективной деятельности и общению в поликультурной среде, что связано с осознанием культурного многообразия, толерантным отношением к этому многообразию и способностью к культуросообразному поведению (в соответствии конкретным культурным условиям).

Как было сказано, поликультурность - непреходящее свойство социальной реальности, влияние которого на развитие общества и эффективность индивидуальной жизнедеятельности личности возросло сегодня в связи с повышением открытости общества, глобальными интеграционными процессами. Наиболее очевидно потребность в поликультурной подготовке подрастающего поколения осознается в этническом аспекте, поскольку межнациональные проблемы и, как следствие, конфликты затрагивают большие группы людей. Это особенно важно для России - традиционно многонационального государства, полиэтнический состав которого всегда дает возможность в случае жизненных затруднений найти «врага» среди представителей иного народа, а 
недобросовестным политикам - спекулировать на национальных чувствах, раздувая национальный экстремизм.

Однако и остальные аспекты поликультурности общества сегодня становятся причиной, если не конфликтов, то индивидуальных затруднений, прежде всего, коммуникативного характера. Следует отметить, что в России (вслед за остальным цивилизованным миром) в последние десятилетия произошел поворот общественного сознания (и, следовательно, образовательной парадигмы) в направлении индивидуально-личностного подхода к каждому члену социума, признания, по меньшей мере, «равноправия» индивидуальных и общественных интересов, признания за каждым человеком права «быть собой» и т.П. Гуманность, справедливость подобных изменений очевидна - однако в понятие самобытности личности можно включить не только ее индивидуальные способности, но и интересы, попадающие под определение вкуса (художественные, профессиональные), особенности мировосприятия и отношения к тем или иным событиям, зависящие пола и возраста, установки, ценности, поведенческие стереотипы, выработанные в процессе профессионального труда и т.д. Отстаивая свой личный суверенитет, люди (особенно, молодежь), зачастую забывают, что человек, все-таки, социальное существо, а для эффективного взаимодействия необходимо уметь договариваться, не смотря на различия. Как следствие усилившееся недопонимание, неприятие друг друга людьми разного возраста, пола, профессий, социального статуса и т.д.

Г.Д.Дмитриев писал: «У всех и каждого есть культура как стиль жизни, как совокупность менталитета, традиций, арго, акцента, диалекта, стиля одежды и прически, кухни, правил поведения, песен, напевов, сказаний, литературы, символов, родо-половых и физических данных, отношений, нравственных и эстетических ценностей, образования, трудовых навыков, веры, только она - культура - разная. Не хорошая и плохая, высокая и низкая, полноценная и неполноценная, развитая и неразвитая, 
цивилизованная и примитивная, а разная, не похожая одна на другую, имеющая свои достоинства и недостатки, плюсы и минусы, сильные и слабые стороны» [60, с. 37]. Осознание данного факта является, на наш взгляд, отправной точкой развития поликультурной личности.

В целом поликультурная личность должна обладать следующими характеристиками:

- осознание поликультурности общества, участие в межкультурном взаимодействии с позиций гуманизма, толерантности, культурного плюрализма;

- национальная идентичность и способность к познанию ценностей разных национальных культур, к самореализации в полиэтнической среде;

- восприятие культурного разнообразия общества как основы культурного прогресса цивилизации, стремление и способность к культурному обмену и взаимообогащению;

- культурная рефлексия и самооценка [19,34,108,158,181 и др.].

Особое значение имеет поликультурная подготовка в контексте профессиональной подготовки будущих учителей. С одной стороны, педагоги - такие же члены социума, являющиеся носителями целой совокупности культурных пластов: национальной, гендерной, профессиональной и т.д. В процессе жизнедеятельности они взаимодействуют с представителями разных социальных групп, для них характерны общие проблемы межкультурной коммуникации, связанные с пониманием и способностью договориться с представителями иной культуры (со своими родителями и детьми, работниками сферы обслуживания и системы здравоохранения, с друзьями, имеющими иные литературные и художественные вкусы, иные хобби, с коллегами другой национальности или вероисповедания и т.п.).

С другой стороны, поликультурная подготовка будущего учителя имеет профессиональную значимость, что связано как педагогической 
миссией, так и с сущностью педагогического труда, и социальной средой, в которой осуществляется педагогическая деятельность.

Педагогическая деятельность осуществляется на фоне общения (в режиме общения), общение - деятельность, посредством которой педагог реализует свои профессиональное функции. «С точки зрения профессионализма наиболее значимой и сложной стороной педагогического труда является общение, поскольку... через общение осуществляется ... воздействие личности учителя на личность ученика» [108, с.12]. В свою очередь, общение невозможно без установления межличностных отношений [51,78,119], а каждая личность является носителем собственной, в чем-то обязательно отличной от других, культуры. И именно в общении, во взаимодействии между людьми актуализируются их культурные сходства и различия, которые могут стать как основанием, так и препятствием для взаимопонимания и взаимодействия, поскольку «межкультурные особенности общения охватывают различия межнационального, гендерного, социального, демографического, языкового и пр. порядка» [57].

Поскольку в поликультурном обществе коммуникационные проблемы возникают как результат взаимоотношений (контактов) субъектов культурных различий, воспринимаемых как «Враг», «Другой» или «Чужой» [48], педагогу, важно уметь воспитывать учащихся таким образом, чтобы, условно говоря, «Другой» воспринимался скорее как «Друг», а не как «Враг» или «Чужой». Для этого учитель должен быть компетентным, с одной стороны, в области психологических предпосылок конструктивного общения (интерес к человеку, эмпатия и сопереживание, ориентация на лучшие качества коммуниканта и др.) и способов и закономерностей успешной коммуникации [108], с другой - в вопросах препятствий к установлению конструктивного общения, причин непонимания и негативного восприятия друг друга участников общения, к которым относятся и факторы, связанные с культурными различиями (например, негативные установки относительно 
представителей иных национальностей, профессий, субкультур и т.п.). При этом «профессионализм педагогического общения проявляется в готовности и умении использовать полученные знания на практике, в выработке собственных установок поведения и общения, в готовности к сотрудничеству с учащимися и их родителями, эмоциональной контактности, проявляющейся в отзывчивости, способности к сопереживанию, в высоком уровне эмоциональной стабильности, педагогической толерантности в разных конфликтных ситуациях» [108, с.16].

Исследуя проблемы межкультурной коммуникации в полиэтническом обществе, И.А.Мальковская отмечает, что их наибольшая острота наблюдается в так называемых «зонах пересечения культур»: интересов, миграций, политической неопределенности, «иных гражданств» - наиболее уязвимых точках стабильности поликультурного общества, соседствующего с другими территориям и испытывающего «миграционный нажим». Рассматривая проблему в территориальном аспекте, автор называет «пограничье» зоной коммуникативного обмена различиями и формирования отличий, где сегодня происходят важнейшие процессы соприкосновения культур [97]. В контексте нашего исследования «территория» (область, среда,) педагогической деятельность также является зоной пересечения культур: национальных и возрастных, профессиональных и статусных, гендерных и субкультурных.

Педагогическое общение включает все многообразие коммуникаций учителя - с учащимися, с их родителями, коллегами, администрацией [78, 108]. Профессиональный коллектив, в котором работает педагог, отличается поликультурностью по всем возможным основаниям: национальному, гендерному, возрастному, субкультурному и т.д. В случае, когда педагог осведомлен и толерантен относительно представленных в коллективе культурных ценностей, установок, традиций и т.п., его деятельность может стать мощным средством установления взаимопонимания и взаимодействия. 
В свою очередь, «взаимовлияние и взаимопроникновение культур ведет к аккультурации членов социумов, соединяющих в своем сознании разные культуры, ориентированных на другого, предрасположенного к диалогу с ним» [57].

Культурный фон педагогической деятельности, в соответствии с объектами профессионального взаимодействия, характеризуется следующими различиями:

- национальными (и религиозными) - между членами педагогического коллектива, внутри ученического коллектива, и соответственно, коллектива родителей;

- возрастными и гендерными - внутри педагогического коллектива, а также между педагогами и учащимися, педагогами и родителями учащихся;

- социально-статусными - между педагогами и администрацией, педагогами и родителями определенного социального статуса (воспринимаемого как более высокий либо низкий);

- профессионально-ценностными - между педагогами, придерживающихся различных педагогических концепций, парадигм, а также между педагогами и родителями учащихся как представителями иных профессиональных сообществ.

Bсе указанные различия могут стать источниками напряжения, коммуникативных проблем, если педагоги не готовы к деятельности в поликультурном сообществе. Так, например, профессионально-ценностная интолерантность препятствует обмену педагогическим опытом, некомпетентность в области межэтнических культурных различий может стать причиной национальной нетерпимости и т.д. В этой связи педагогу следует учитывать ряд особенностей построения профессионального общения, охарактеризованных И.А.Колесниковой:

- чем моложе учитель, тем адекватнее его восприятие и понимание реалий, ценностей, проблематики, атрибутики, мотивов поведения учащихся; 
однако, не зависимо от возраста педагога, учащиеся высоко ценят его знакомство с миром молодежи, понимание его отличий, сочувствие проблемам и т.д.;

- принадлежность к различным национальным и религиозным (в том числе, атеистической) культурам обусловливает разные традиции во взаимоотношениях полов, «отцов и детей», разный строй мышления (мифологический, рациональный, прагматический), разные ценностные ориентации; осведомленность, учет и уважительное отношение к этим особенностям - важное условие установления конструктивных педагогических отношений;

- между всеми участниками педагогического общения существует разница в культурном уровне, связанная с местом рождения и получения образования, привычной социальной средой, культурными предпочтениями, а также социальным статусом, что также требует специальной подготовки при организации взаимодействия и др. [78].

Особую важность, с точки зрения содержания педагогического труда, имеет поликультурность коллектива учащихся, поскольку непосредственно связана с профессионально-педагогической миссией. (Взаимодействие с инокультурными коллегами и родителями учащихся, на наш взгляд, во многом идентично общим особенностям, закономерностям жизнедеятельности в поликультурном обществе, и в меньше степени, нежели взаимодействие с учащимися, связано с профессиональной деятельностью).

В этой связи интересна работа Е.А.Нечаевой, которая, хотя и выполнена в этнокультурном аспекте, однако позволяет определить основные поликультурные характеристики ученического коллектива и связанные с этим функции педагога, определяющие, наряду с прочим, направленность и содержание профессиональной подготовки будущего учителя. Перефразируя авторское определение мультикультурного коллектива учащихся как педагогического феномена, можно сказать, что 
поликультурный коллектив учащихся представляет собой группу взаимодействующих, совместно обучающихся лиц, каждое из которых является носителем определенных национальных (этнокультурных), психологических (возрастных, гендерных), мотивационно-ценностных (в том числе, связанных с семейными традициями) особенностей, оказывает культурное влияние на других и одновременно находится под влиянием каждого из членов группы [108]. По сути, педагог, непосредственно в процессе образовательной деятельности, сталкивается со столькими индивидуальными культурами, сколько учащихся в конкретном классе. Эффективность его труда зависит, в том числе, от способности учитывать данное культурное разнообразие и эффективно использовать в работе.

Эффективность педагогической деятельности в мультикультурном коллективе учащихся, по мнению Е.А.Нечаевой, связана со следующими знаниями, умениями, личностными качествами учителя:

- знание функций, которые может выполнять мультикультурный коллектив учащихся, и грамотное использовать его воспитательного потенциала;

- знание особенностей и основных ценностей представленных в коллективе культур, умение предвидеть возможные взаимоотношения внутри классного коллектива, с родителями детей - представителями разных культур, способность учитывать основные культурные ценности, установки, традиции и т.д.;

- знание сущностной характеристики мультикультурного коллектива учащихся, способность вносить коррективы в собственную педагогическую деятельность, в свои планы, в содержание воспитательной работы [108].

В более широком понимании, соответствующем идее нашего исследования, поликультурность профессионально-педагогической среды требует от педагога желания и умений определять состав и поликультурные особенности своего профессионального окружения, толерантно относиться к 
этим особенностям и уметь выстаивать конструктивные взаимоотношения, основанные на интересе, уважении и компетентности в области иных культур.

На педагогах лежит огромная ответственность по воспитанию подрастающих поколений и, в том числе, по подготовке учащихся к жизни в поликультурном обществе, следовательно, он должен быть компетентен в вопросах поликультурного образования.

И.В.Васютенкова, характеризуя поликультурность как дидактический принцип, отмечает, что он отражает принцип множественности культур, слагающих культуру российского общества, и является интегрирующим фактором современной культуры, поскольку направлен на изменение отношения учащихся к миру, к самим себе, на расширение понятия идентичности в содержательном плане [34]. Абстрагируясь от этнического контекста авторского мнения, можно сказать, что поликультурность образования предполагает конструирование такого содержания, в котором находят отражение особенности всех культур, представленных в образовательном пространстве и вне его (регионе, государстве, мире) (И.В.Васютенкова).

Важнейшим

основанием поликультурного образования (или поликультурного принципа организации образовательного процесса) большинством российских педагогов признается идея диалогового подхода. Так, А.В.Шафрикова отмечает, что поликультурное образование направлено на сохранение и развитие всего многообразия культурных ценностей, норм, образцов и форм деятельности, существующих в данном обществе, и базируется на принципах диалога и взаимодействия различных культур [178].

Диалоговый подход основан на идеях открытости, диалога культур, культурного плюрализма и отличается от аккультурационного подхода, по принципам которого изначально строилось поликультурное образование. С 
позиций аккультурационного подхода поликультурное образование включает в себя изучение традиций собственной культуры и переработку этих традиций в рамках новой культуры, (так как противоречия с изменившимися условиями жизни обусловливают необходимость в выработке новых культурных ориентиров [185,]. Диалоговый подход рассматривает поликультурное образование как способ приобщения учащихся к различным культурам с целью формирования общепланитарного сознания, позволяющего тесно взаимодействовать с представителями различных стран и народов и интегрироваться в мировое и общеевропейское культурнообразовательное культурно-образовательное пространство, сохраняя собственную культурную индентичность. Различные культуры в данном случае не отвергаются, не ассимилируются, а сосуществуют и взаимодействуют [21,22]. Поскольку различные культуры равноценны и равноправны, то единственный путь конструктивного взаимодействия между ними - диалог.

Вопросы диалога в контексте культуры начали изучаться и разрабатываться в начале XX века К.Ясперсом, О.Шпенглером, М.Бубером, М.Бахтиным и, позднее, Л. Баткиным, М.Каганом, П.Гайденко, В.Библером и др. Важным для нашего исследования выводом является сложившееся представление о том, что в историческом плане постоянно велся и ведется диалог между культурами, соответствующими различным религиозным, идеологическим, национальным, профессиональным системам; что диалог разворачивается и во времени (в том числе, между представителями разных поколений), и в пространстве (между представителями разных народов, профессий, субкультур и т.д.). В этой связи основной задачей поликультурного образования можно назвать помощь и поддержку представителям всех контактирующих культур придти к взаимопониманию посредством воспитания таких качеств, как взаимная открытость, интерес и терпимость [36]. 
Взаимопонимание возможно в том случае, когда анализируемое явление (предмет межкультурного общения) интерпретируется в представлениях своей и иной культуры, принимая их (представления) как равные ценности, не отторгая иное представление. Е.Н.Матюхина определяет взаимопонимание как признание взаимной ценности в сходстве и различии, как межчеловеческое и межкультурное взаимодоверие и взаимодополняемость идеалов и смыслов [100].

Анализ исследований, посвященных диалоговому подходу к поликультурному образованию, позволяет констатировать следующую иерархию педагогических целей-ориентиров:

- обеспечение понимания учащимися культурных различий между людьми и воспитание на этой основе толерантности, терпимости к иному образу жизни, мировосприятию и стилю поведения [186,187];

- обеспечение осознания учащимися влияния культурных различий на эмоциональную сферу человека и развитие способности воспринимать поликультурность как источник собственных переживаний, потребностей и мотивов [190];

- развитие у воспитанников способности дифференциации внутри чужой культуры, умения оценивать инокультурные системы ценностей и норм по степени их исторически-конкретной важности для определённых видов деятельности [189];

- формулирование у учащихся способности интегрировать элементы других культур в собственную систему мышления и ценностей [187].

Диалоговый подход в поликультурной подготовке учащихся, по мнению ряда исследователей, неразрывно связан с идеей деятельностного подхода к образованию. В частности, авторы деятельностной концепции поликультурного образования Е.Ф.Тарасов и Ю.А.Сорокин справедливо отмечают, что иная культура усваивается исключительно в процессе деятельности, непосредственному осуществлению которой предшествует 
этап ориентировки в условиях деятельности. Этот этап связан с осознанием усваиваемых фрагментов чуждой культуры, их «переформулирование» в терминах собственного культурного опыта - то есть, происходит экстраполяция мыслительных действий, сформированных в одной сфере (в данном случае, когнитивно-ценностной сфере) деятельности, в другую [146].

На деятельностную сущность процесса развития поликультурности личности указывают и многие зарубежные ученые: Г.Поммерин, М.Хоманн, У.Зандфукс, Циммер и др. Они считают поликультурное образование деятельностно-ориентированным и основанным на признании индивидуальных различий и воспитании в духе мира путем разрешения межкультурных конфликтов, что предполагает: а) признание наличия межкультурных конфликтов, б) совместное их разрешение, в) обогащение за счет диалога с чужими культурами [192.193 и др.]. В этой связи Гепферт формулирует некоторые критерии или постулаты, которым должны соответствовать образовательные программы. «Другие народы и культуры должны рассматриваться не как объекты, а как исторические субъекты. Необходимо показывать представителей других культур в их жизненной ситуации, вместе с их стилем жизни, традициями, особенностями и жизненными обстоятельствами» [188, с.43].

В содержательном плане поликультурность образования предполагает насыщение образования поликультурным знанием ценностногуманистического характера, включающего: гуманистические идеи равноценности людей не зависимо от национальной, расовой, конфессионной и др. принадлежности, свободы и ненасилия; уникальные этнические, религиозные, гендерные, возрастные самобытные черты в культурах разных социальных групп, в том числе, народов региона и мира; знания об общем и особенном разных культур: элементах традиций и установок, позволяющих жить в мире, согласии, терпимости, гармонии; основы мировой культуры, сущность процесса глобализации, взаимозависимости стран и народов в 
современных условиях; информация о происходящих в мире разносторонних культурных обменных процессах и многоуровневой структуре каждой культуры; идеи толерантности к иного рода взглядам, привычкам, к особенностям представителей различных социальных групп и т.д.

Таким образом, поликультурность образования предполагает диалогичность, деятельностную ориентацию и контекстность образовательного процесса.

В целом, как отмечает Шмидт, основной задачей поликультурного образования должно быть развитие у субъектов образования способности к межкультурной коммуникации [194]. В этом случае педагог должен в процессе профессиональной деятельности опираться на принцип поликультурности и при организации учебной деятельности, и при реализации воспитательных функций.

Bce вышесказанное позволяет утверждать, что поликультурная подготовка будущего педагога включает два взаимосвязанных аспекта: подготовка студентов к жизнедеятельности в поликультурном обществе и их педагогическая подготовка к осуществлению образовательного процесса с опорой на идеи поликультурного образования.

Результатом поликультурного образования будущих педагогов является формирование у студентов поликультурной компетентности, что соответствует современным тенденциям в образовании. Поликультурность важная характеристика современного социума, а сформированность поликультурной компетентности - одно из ключевых условий эффективного взаимодействия человека в современном социуме. 


\section{2. СУЩНОСТЬ ПОЛИКУЛЬТУРНОЙ КОМПЕТЕНТНОСТИ ПЕДАГОГА.}

Bce многообразие определений понятия «компетентность» можно свести к двум большим группам по основанию отраженного в них компонентного содержания данного качества.

Определения первой группы характеризуют компетентность как когнитивно-инструментальное образование, «привязанное» к предметной сфере жизнедеятельности и профессиональной деятельности, в частности. Так, Г.М.Коджаспирова профессиональную компетентность педагога определяет как владение специалистом необходимой суммой знаний, умений и навыков, обусловливающих становление эффективности его профессиональной деятельности и общения, а также развития личности (в совокупности профессиональных ценностей, идеалов и сознания) [76]. Е.П.Тонгоногая, исследуя вопросы содержания и способов развития профессиональной компетентности руководителя, выделяет в составе компетентности как интегрального качества личности взаимосвязанные опыт, знания, умения и навыки [120]. Л.М.Митина придерживается общепринятой в психологии (по словам автора) позиции к определению компетентности через совокупность знаний, умений, навыков, способов и приемов их реализации в деятельности, общении и развитии личности [105]. В еще более узком смысле - как систему определенных знаний рассматривают компетентность в одной из работ А.А.Реан и Я.Л.Коломенский [124].

В определениях второй группы компетентность представлена как качество более широкого плана. Дж.Равен, характеризуя сущность компетентности как мотивированной способности, необходимой для эффективного выполнения определенной предметной деятельности, включает в ее состав узкоспециальные знания, предметные навыки, способы 
мышления, а также понимание ответственности за свои действия. Он пишет, что компетентность состоит «из большого числа компонентов, многие из которых относительно независимы друг от друга... некоторые компоненты относятся скорее к когнитивной сфере, а другие - к эмоциональной... эти компоненты могут заменять друг друга в качестве составляющих эффективного поведения» [122, с.153] При этом ученый придает приоритетное значение в составе компетентности ценностному отношению субъекта труда к предмету деятельности [122,123].

О.М.Атласова включает в состав компетентности, наряду со знаниями, умениями и навыками, еще и способности, личностные качества, а также готовность к деятельности [8]. В.И.Байденко, определяя компетентность как обладание компетенциями, в качестве еe составляющих рассматривает способности, готовность познания и отношения (образы поведения), необходимые для выполнения деятельности [9]. Еще более широкий круг качеств относят к компетентности В.А.Попков (о профессиональной компетентности преподавателя высшей школы): любовь к профессии, потребность в самосовершенствовании, специальная подготовленность, опыт и профессионально значимые личностные качества [119], Е.В.Бондарева: знания, навыки творческой деятельности, стиль мышления и нормы этики; мотивы, цели, потребности, ценностные установки актуализации в профессиональной деятельности; навыки самоконтроля, самоанализа, прогнозирования результатов своей деятельности; способности налаживать межличностные отношения, формулировать мысли, доходчиво излагать информацию, осуществлять профессиональное взаимодействие и др. [27].

Какой бы состав качеств ни включался в компетентность, общим является ее свойство: обеспечение эффективности жизнедеятельности в широком смысле, либо профессиональной деятельности личности $[49,67,147]$. 
Мы согласны с мнением ученых, занимающих промежуточную позицию между узко-когнитивным (или когнитивно-инструментальным) и слишком широким рассмотрением структурного состава компетентности, и описывающих компетентность как совокупность контекстных знаний и деятельностно-поведенческих умений, способностей применять теоретические знания, а также мотивационно-ценностных характеристик личности, лежащих в основе таких отношений к действительности, которые обусловливают ее стремление действовать в соответствии с полученными знаниями и совершенствовать умения и навыки. Подобная точка зрения явно или неявно отражена в работах Е.А.Нечаевой, 3.Н.Сафиной, С.А.Хазовой, Е.А.Щегловой и других ученых.

3.Н.Савина, анализируя ключевые компетенции (высокий уровень освоения которых определяет соответствующую компетентность личности), выделяет в их структуре знания, умения и навыки, которые необходимы для осуществления конкретной деятельности. В свою очередь, умения рассматриваются как способность и готовность эффективно применять знания на практике, в конкретной ситуации [131]. Готовность же к деятельности, по мнению большинства ученых, обязательно предполагает определенное внутреннее состояние личности: его мотивы, направленность, целевую и ценностную ориентацию и т.п. [50,134,157] .

Е.Н.Нечаева, характеризуя готовность педагога к деятельности в мультикультурном коллективе учащихся с позиций компетентностого подхода, связывает ее с наличием знаний и умений межкультурного характера, ценностных ориентаций педагога, определяющих профессиональную позицию по отношению к многообразию этносов, населяющих территорию России; в качестве критериев называются цели, ценностные ориентации, знания, способности и умения [108].

С.А.Хазова в структуре профессиональной компетентности специалитов по физической культуре и спорту выделяет когнитивно- 
интеллектуальный, $\quad$ морально-психологический $\quad$ и деятельностноповеденческий компонентьл. Когнитивно-интеллектуальный компонент включает совокупность знаний, умений и особенностей мышления, «обеспечивающчих развитие конкретных компетенщий, личностных качеств и компонентов направленности личности» [168, с.51]. Деятельностноповеденческие характеристики описываются через опыт поведения, общения и деятельности, где опыт - это «качество личности, сформированное в прочессе ее деятельности, обучения и воспитания, обобщающее знания, умения, навыки и привычки», соответствующие контексту деятельности, в которой формируется и проявляется опыт [168, с.52]. Морально-психологические составляющие компетентности включают качества, относящиеся $\kappa$ сфере направленности личности (иенностные ориентации, мотивацию и др.) и ее способностей [168].

Основываясь на вышеприведенных мнениях, мы также выделяем в структуре поликультурной компетентности педагога три компонента:

- когнитивный, включающий спектр знаний и теоретических умений, необходимых для эффективной жизнедеятельности в поликультурной среде;

- мотивационно-ценностный, характеризующийся освоением гуманистических ценностей, относящихся к жизни в поликультурном обществе, толерантные отношения к представителям иных социальнокультурных групп и мотивацию к межкультурному взаимодействию;

- деятельностно-поведенческий, включающий умения разрешать межкультурные проблемы, эффективно действовать в поликультурной среде, осуществлять активное взаимодействие с представителями различных культур.

Уже из приведенных определений компетентности видно, что, не зависимо от структуры, можно выделить два ее вида: профессиональную и относящуюся к внепрофессиональной сфере жизнедеятельности человека (ключевая, базовая, общесоциальная и т.п.), чему соответствует наш взгляд 
на цели поликультурной подготовки педагогов, а именно, ее направленность на развитие общесоциальных качеств поликультурной личности и профессионально заданных поликультурных качеств педагога.

Согласно содержанию международных документов, материалов ЮНЕСКО, касающихся обновления содержания образования, поликультурная компетентность относится к основополагающим компетентностям современного человека. Так, в докладе международной комиссии по образованию для XXI века «Образование: сокрытое сокровище» Жак Делор определил глобальные компетентности - «столпы», на которых основывается образование: научиться познавать, научиться делать, научиться жить вместе, научиться жить [56].

С.Е.Шишов и В.А.Кальней приводят содержание принятых Советом Европы содержание пяти ключевых компетенций, к которым относятся и компетенции, связанные с жизнью в многокультурном обществе, препятствующие проявлению (возрождению - resurgence) расизма и ксенофобии и развитию интолерантности: принятие различий, уважение других и способность жить с людьми других культур, языков и религий [179].

В общесоциальном контексте представляется поликультурная компетентность и при анализе модели компетентности личности, разработанной и принятой участниками программы TUNING («Настройка образовательных структур») - представителями более 100 университетов из 16 стран, подписавших Болонскую декларацию. Модель включает две группы компетенций (общих и специальных). Хотя поликультурная компетентность не выделяется (поскольку авторы выделяют компетенции по иным основаниям), однако содержание общих компетенций включает и те, что относятся к области межкультурного взаимодействия людей: коммуникативные знания и умения, социальные навыки, связанные с процессами социального взаимодействия и сотрудничества, умением 
работать в группах, принимать социальные и этические обязательства, навыки межличностных отношений и способность воспринимать разнообразие и межкультурные различия, способность работать в международной среде и приверженность этическим ценностям, понимание культур и обычаев других стран и др.

В таком же ключе поликультурная компетентность характеризуется 3.Н.Сафиной, М.Н. Певзнером, В.О. Букетовым, О.М. Зайченко, Е.С.Деньгуб и др. В частности, Е.С.Деньгуб раскрывает содержание межкультурной компетентности (через межкультурные компетенции) следующим образом: «чувствительность к культурным различиям, уважение к уникальности культуры каждого народа, терпимость к необычному поведению, желание позитивно относиться ко всему неожиданному, готовность реагировать на изменения, гибкость в принятии альтернативных решений и отсутствие завышенных ожиданий от общения с представителями других культур» [57].

Таким образом, поликультурная компетентность относится к области общесоциальных, не зависящих от профессии, компетентностей современного человека. Она во многом обеспечивает активную жизнедеятельность человека, его способность ориентироваться и адекватно воспринимать различные сферы социальной действительности, гармонизирует внутренний мир личности и ее отношения с обществом [55]. Когнитивное содержание общесоциальной поликультурной компетентности составляют базовые знания, связанные с наличием и сущностью межкультурных различий. На основе этих знаний формируется чувствительность и ценностное, уважительное отношение к культурным различиям, осознание уникальности культур, терпимость и позитивное отношение к необычному поведению и мышлению, отсутствие завышенных ожиданий от общения с представителями других культур и т.д. [34].

Однако, для педагога данное качество имеет и профессиональное значение. Как справедливо отмечает Г.Д.Дмитриев, именно будущим 
учителям особенно важно «уметь работать с различными в культурном отношении людьми, правильно понимать человеческое различие, быть толерантными к ним, уметь утверждать своими личными делами и словами культурный плюрализм в обществе» [60, с.116]. Поэтому содержание поликультурной компетентности педагога должно быть шире, чем у иных граждан, что, как уже говорилось, связано с сущностью педагогической деятельности: специалисты данной сферы должны не только уметь жить в поликультурной среде, взаимодействовать с ее представителями, но и быть активными «проводниками» идей культурного плюрализма, осуществлять поликультурное воспитание учащихся.

Профессиональное содержание поликультурной компетентности педагога связано с такими аспектами, как:

- осознание поликультурных особенностей профессионального окружения, в том числе, ученического коллектива, связанных с национальнорелигиозной, возрастной, гендерной и иной принадлежностью, уважительное отношение к ним,

- умение действовать сообразно культурным особенностям субъектов педагогической деятельности, сохраняя при этом собственную культурную идентичность,

- способность организовать конструктивное межкультурное взаимодействие в коллективе и использовать межкультурные различия для обогащения личного культурного опыта субъектов взаимодействия,

- знание и учет психологических особенностей восприятия и поведения личности, обусловленных ее культурной принадлежностью,

- способность обеспечивать поликультурную направленность учебновоспитательного процесса, прогнозировать, предупреждать и разрешать межкультурные конфликты в коллективе и т.д. [19,34,47,52,73,103,108,158].

Поскольку знания о сущности межкультурных различий являются, на наш взгляд, важнейшей основой формирования ценностного, толерантного 
отношения к представителям иных культур, становления навыков конструктивного (бесконфликтного) межкультурного взаимодействия, то важно определить, какие именно типы различий должны быть усвоены и осознаны.

Ю.П.Тен в философском исследовании сущности и значения символов в межкультурной коммуникации, определяет культуру как символическую систему, «в которой выражаются ключевые идеи, ценности, нормы и стандарты определенного общества и культуры» [149, с.24]. В контексте нашей работы можно сказать, что ценности и ценностные отношения, нормы и стандарты поведения и деятельности относятся к основаниям, по которым можно определить культурные различия. Согласно авторской классификации символов, сами культуры подразделяются на социальные, этнические, мифологические и религиозные, художественные, политические и государственные. Причем, следуя логике автора, культурные идеалы, ценности, нормы и т.д. репрезентируются носителями культуры в виде представлений о роли и месте данной культурной группы в мире [149] и, следовательно, в виде отношения к себе, к миру, к окружающим - на основе определения степени соответствия объекта отношения интериоризированным культурным нормам. В частности, Ю.П.Тен отмечает, что социальные символы отражают идейно-ценностные и нормативно-обыденные представления о месте и роли определенных социальных групп, существующих в обществе; к таким группам, на наш взгляд, можно отнести не только классы, но и профессиональные сообщества, возрастные и гендерные группы. Этнические символы выражают особенности социокультурной жизни нации и воплощают объединяющие идеи, идеалы и ценности; религиозные - отражают представления о сущности человеческого и божественного, о месте и роли человека в мире, его связи с Богом, а также 


\section{2. СУЩНОСТЬ ПОЛИКУЛЬТУРНОЙ КОМПЕТЕНТНОСТИ ПЕДАГОГА}

нравственно регламентируют отношения между людьми (ценность человека) и т.д. [149].

Аналогичного мнения придерживается И.Л.Плужник, отмечая, что полноценное освоение культуры возможно только через понимание присущих ей имплицитных (скрытых, ненаблюдаемых) составляющих ценностей и ценностных ориентаций, базовых представлений и норм. Ценности, пишет автор, будучи присвоенными в деятельности, характеризуют отношения человека к материальным и идеальным, духовным явлениям, к событиям и социуму, и становятся его ценностными ориентациями. Ценностные ориентации регулируют коммуникативные действия личности, образ мышления и установки, эмоции, лежащие в основе поведения. «Нормы, основанные на моральном коде, преломляют ценности культуры в виде общепринятых, стандартных образцов действий человека в социуме, являются своего рода эталонами ожидаемого поведения в прототипных ситуациях и, при условии их принятия индивидом, являются регулятивами его поведения» [117, с.10]. Опираясь на исследования В. Гудикунста, Ю. Кима, Г.Хофстеда, Т. Парсонса, И.Л.Плужник выделяет культурные переменные (основные критерии измерения культурных различий), к которым относит: индивидуализм/коллективизм (характеризуется, в частности, степенью значимости личных и общественных интересов и целей); маскулинность/фемининность (определяются, вопервых, представлениями о дифференциации половых ролей, во-вторых, с активно-творческим, культурным либо пассивно-репродуктивным, природным началами [177]); степень допускаемой представителями культуры эмоциональной экспрессивности (может выражаться в строгой рациональности общения, в проявлении чувств либо пресекании аффективных проявлений); высококонтекстность / низкоконтекстность 
(степень точности понятий); дистанция власти (в целом, на наш взгляд, дистанция в общении) и др. [117].

Субъект-объекты ценностных отношений и поведенческих реакций косвенно отражены в работе С. Н. Иконниковой, В. П. Большакова (с соавторами). Анализируя традиции и современное состояние изучения культуры повседневности на основе изучения большого количества источников, авторы характеризуют последнюю с точки зрения интереса к: среде обитания (обитания: природа, город, деревня, жилище), собственному телу (забота о его природных и социокультурных функциях: питание, физические упражнения, гигиена, врачевание, одежда), - обрядам, связанным с рождением, созданием семьи, смертью, - семье, семейным отношениям, межличностным отношениям в других микросоциальных группах (профессиональных, конфессиональных и др.) [150]. То есть, к основаниям межкультурных различий можно отнести ценностные отношения к природе и Отечеству (как «макродому»), к себе, своему здоровью и внешнему виду, к семейным отношениям, традициям, определению «главы семьи», а также роли и правил поведения в семье остальных ее членов, к представителям старших и младших возрастных групп и т.д.

О социально-нормативных и ценностно-ориентационных основаниях культурных различий свидетельствуют также исследования А.В.Алешиной, А.Р.Лурии, Л.В.Полякова и других ученых. Таким образом, базовые элементы культуры - ценности и идеалы, воплощенные в ценностных ориентациях личности, установки (прежде всего, отношенческие), нормы и стереотипы поведения - являются и основаниями для выявления межкультурных различий; сами же различия можно связать с культурными переменными, в которых отражаются базовые элементы культуры (Таблица 1). 
Типизация культурных различий

\begin{tabular}{|c|c|c|}
\hline $\begin{array}{c}\text { Базовые } \\
\text { элементы } \\
\text { культуры - } \\
\text { основания для } \\
\text { выделения } \\
\text { культурных } \\
\text { различий }\end{array}$ & $\begin{array}{c}\text { Примеры культурных } \\
\text { различий, связанных с } \\
\text { культурными переменными }\end{array}$ & $\begin{array}{c}\text { Виды культур - носителей } \\
\text { культурных различий }\end{array}$ \\
\hline $\begin{array}{l}\text { Ценности } \\
\text { ценностные } \\
\text { ориентации }\end{array}$ & $\begin{array}{lr}\text { Индивидуальные } & \text { либо } \\
\text { коллективисткие } & \text { ценности } \\
\text { (индивидуализм } & \text { коллективизм), эгоистическая } \\
\text { либо альтруистическая } \\
\text { ценностная ориентация, уровень } \\
\text { гуманистической } \\
\text { направленности и т.д. }\end{array}$ & $\begin{array}{l}\text { 1.Этнические и религиозные } \\
\text { культуры (определяются по п } \\
\text { национальному и религиозному } \\
\text { составу социального или } \\
\text { профессионального окружения). } \\
\text { 2.Гендерные } \\
\text { (определяется по половому составу } \\
\text { социального кульры }\end{array}$ \\
\hline $\begin{array}{l}\text { Нормы поведения } \\
\text { и общения (семье, } \\
\text { на работе, в } \\
\text { школе, } \\
\text { общественных } \\
\text { местах) }\end{array}$ & 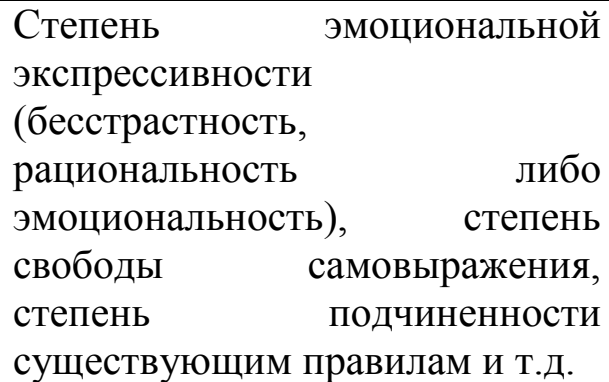 & $\begin{array}{l}\text { профессионального окружения). } \\
\text { 3.Возрастные культуры } \\
\text { (определяются по возрастным } \\
\text { группам, представленным в } \\
\text { социальном } \\
\text { профессиональном окружении). } \\
\text { 4.Субкультуры (определяются по } \\
\text { представленным в социальном или }\end{array}$ \\
\hline $\begin{array}{lr}\text { Отношения } & \text { (к } \\
\text { себе и } & \text { своим } \\
\text { близким, } & \text { к } \\
\text { представителям } & \\
\text { «своей» } & \\
\text { культуры, } \\
\text { представителям } \\
\text { «иной» } \\
\text { культуры), } \\
\text { природе, } \\
\text { Родине) }\end{array}$ & 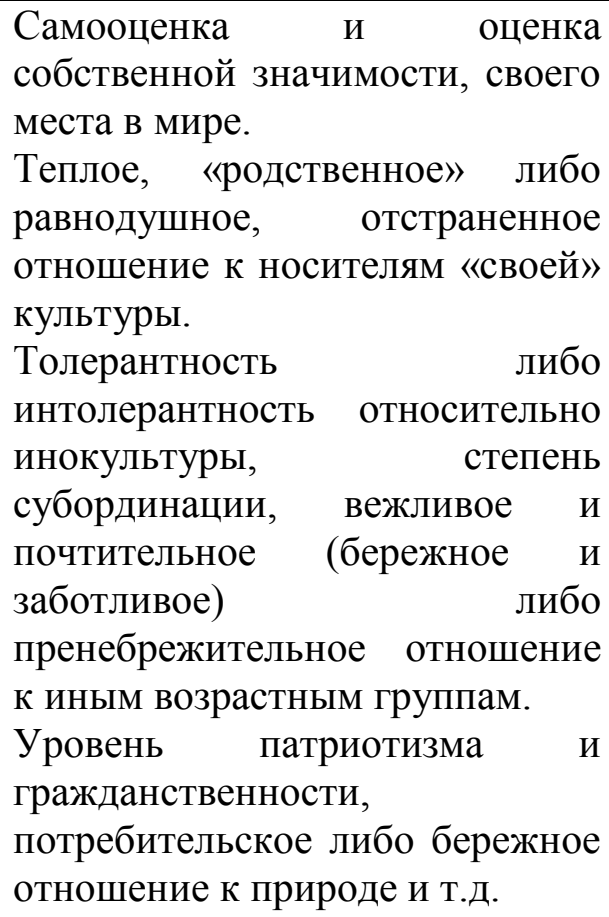 & 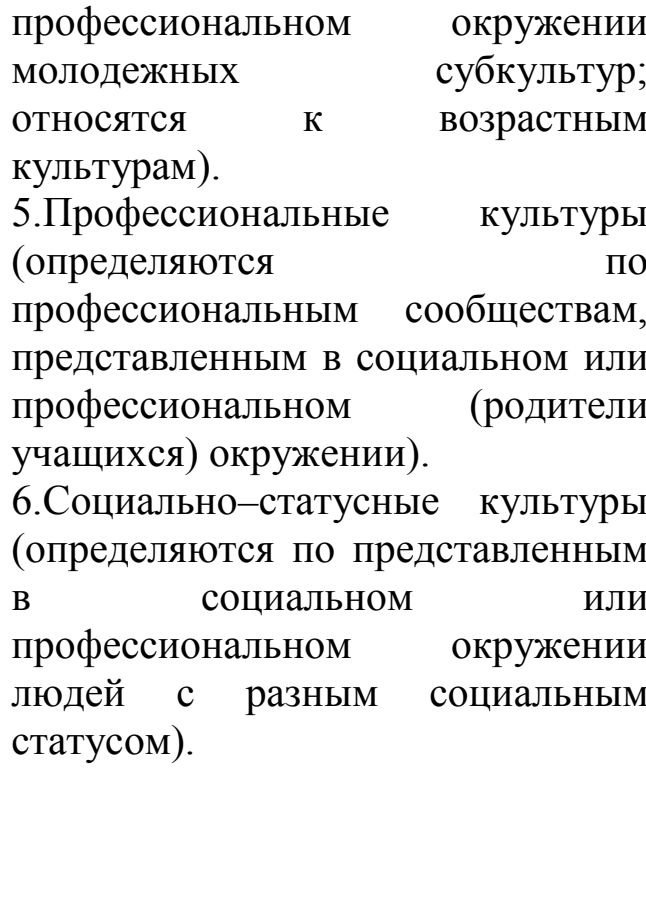 \\
\hline
\end{tabular}


Как утверждает Ю.П.Тен (и другие ученые), проблемы и конфликты в межкультурной коммуникации возникают не столько из-за принципиальных различий в иерархии ценностей, понимании добра и зла, но по той причине, что представители разных культурных групп по разному относятся к тем или иным явлениям и событиям, по разному интерпретируют акты поведения либо фразы (а также мимику) и т.д. В этой связи важным является научиться понимать незнакомую культуру через «расшифровку «чужых» кодов, преобразование их в свои «собственные»» [149, с.34].

Исходя из всего сказанного выше мы определяем поликультурную компетентность педагога как интегративное личностнопрофессиональное качество, обусловливающее его способность эффективно участвовать в социальных процессах поликультурного общества, осуществлять межкультурное взаимодействие, учитывать поликультурный состав субъектов профессиональной деятельности и использовать его характеристики и особенности для решения педагогических задач, a также осуществлять поликультурное воспитание учащихся.

Данное качество предметно описывается через профессиональное и общесоциальное содержание, структурно - как совокупность когнитивного (знания и теоретические умения), мотивационно-ценностного (ценности, отношения, установки) и деятельностно-поведенческого (навыки общения, поведения и деятельности) компонентов. Содержание компонентов нами выделено на основе анализа сущности поликультурности и поликультурной компетентности, содержания межкультурного общения и поликультурного образования, отраженных в исследованиях Е.А.Нечаевой, Т.Б.Менской, И.В.Васютенковой, Д.С.Глембы, А.Г.Бермуса, Е.М.Щегловой, С.М.Федюниной, Г.Д.Дмитриева, Т.Ю.Гурьяновой, И.А.Колесниковой, А.Ю.Белогурова а также в материалах ЮНЕСКО и др. 
Ниже

представлена

структурно-содержательная

модель

поликультурной компетентности педагога (таблица 2).

Таблица 2

Поликультурная компетентность педагога

\begin{tabular}{|c|c|c|}
\hline $\begin{array}{l}\text { Предметно-со- } \\
\text { держательные } \\
\text { компоненты }\end{array}$ & $\begin{array}{c}\text { Общесоциальный } \\
\text { компонент }\end{array}$ & Профессиональный компонент \\
\hline 1 & 2 & 3 \\
\hline Когнитивный & $\begin{array}{l}\text { 3нания в области сущности } \\
\text { культуры, разнообразия и } \\
\text { особенностей субкультур, } \\
\text { их соотношения и и } \\
\text { динамики, особенностей и } \\
\text { закономерностей } \\
\text { межкультурной } \\
\text { коммуникации, культурной } \\
\text { толерантности } \\
\text { интолерантности, } \\
\text { культурной идентичности и } \\
\text { поликультурной сущности } \\
\text { человека. } \\
\text { Умение строить } \\
\text { межличностные отношения } \\
\text { в п्ञ поликультурном } \\
\text { коллективе с учетом } \\
\text { культурных особенностей } \\
\text { участников взаимодействия. }\end{array}$ & 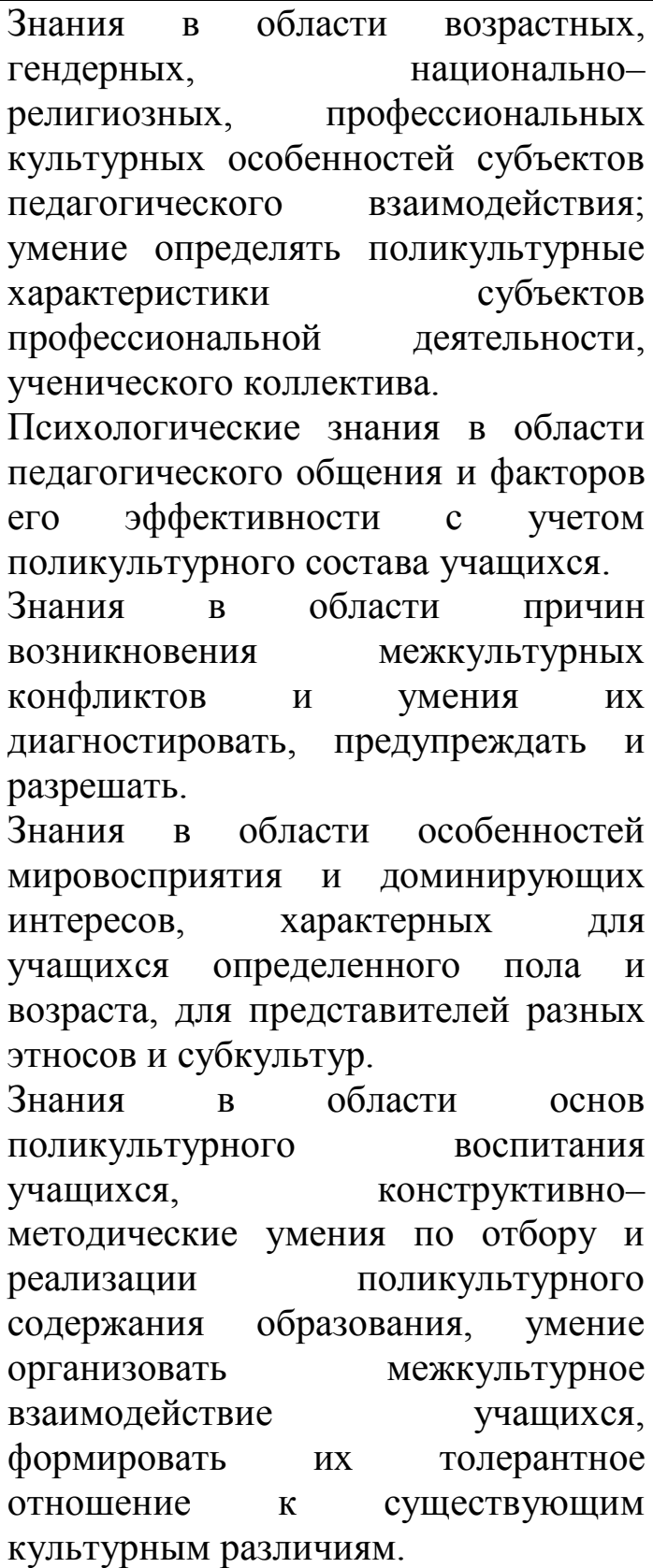 \\
\hline
\end{tabular}


Продолжение таблицы 2.

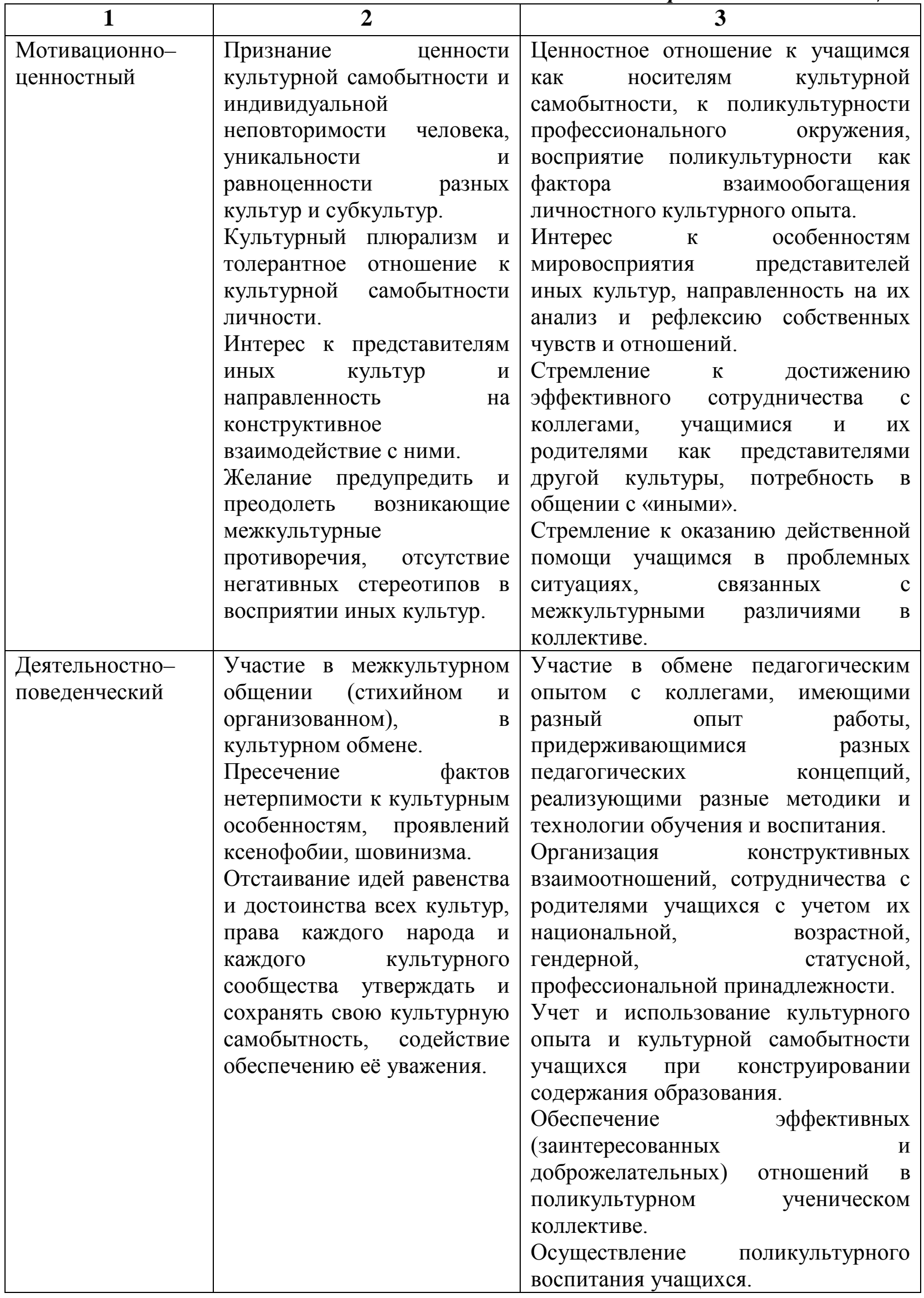


Общесоциальное содержание поликультурной компетентности педагога является фундаментом развития профессиональной составляющей данного качества. Профессиональный аспект представляет собой своего рода экстраполяцию общесоциального содержания в контекст профессиональной деятельности. Исходя из этого нам представляется логичной следующая иерархическая целевая последовательность процесса формирования поликультурной компетентности студентов: от освоения общесоциального содержания межкультурных взаимодействий до экстраполяции этого содержания в коммуникативную сферу профессиональной деятельности и, далее, к подготовке студентов осуществлению поликультурного воспитания учащихся.

Подробно задачи и содержание этапов поликультурной подготовки будущих педагогов будет представлено при описании модели и методики формирования поликультурной компетентности студентов.

Проведенный анализ работ Е.Н.Нечаевой, А.М.Леонтьева, С.М.Тутарищевой, Л.Даниловой, Е.М.Щегловой, Т.Ю.Гурьяновой и др. позволил сделать вывод о том, что степень сформированности поликультурной компетентности может определяться по следующим общим показателям:

1) Когнитивным - системность, полнота и осознанность знаний, отраженных в содержании когнитивного структурного компонента поликультурной компетентности. Системность знаний мы понимаем как способность учащихся охарактеризовать изучаемое явление с научных позиций, отраженных в содержании разных учебных дисциплин; степень системности знаний, таким образом, варьирует от их разрозненности до способности всесторонне, междисциплинарно осветить тот или иной вопрос. Полнота знаний нами определяется как отношение усвоенного личностью объема знаний к общему объему информации, предложенному к изучению. Осознанность знаний определяется как степень их усвоения: репродукция 
(механическое заучивание и воспроизведение без объяснения), понимание и принятие (осмысленное запоминание, свободное изложение, убежденность в истинности знания), применение и творчество (понимание практического значения знаний, обогащение знаний собственными размышлением, опытом) [140].

Оценка знаний может осуществляться в процессе текущего и итогового контроля посредством письменного или устного опросов, тестирования и т.д. на основе традиционных требованиям к знаниям студентов. Когнитивным критерием сформированности поликультурной компетентности является полноценная система междисциплинарных поликультурных знаний, освоенных в полном объеме на уровне применения и творчества.

2) Мотивационно-ценностным - интериоризированность ценностей, выраженность интересов и мотивов, представленных в содержании мотивационно-ценностного компонента поликультурной компетентности. Степень интериоризированности ценностей поликультурности может варьировать: ценности могут не признаваться значимыми, может теоретически признаваться их социальная значимость и отвергаться (полностью или частично) личностная важность, наконец, эти ценности могут осознаваться как личностно значимые для жизни в обществе и эффективной профессиональной деятельности. Контекстные интересы могут отсутствовать в мотивационной сфере личности, могут проявляться ситуативно, детерминируя стремление к определенным действиям и поведению, и могут прочно занимать ведущие позиции в иерархии мотивов поведения и деятельности человека.

Оценка мотивационно-ценностной сферы личности может осуществляться с помощью анкетирования и тестирования, а также в процессе индивидуальных и коллективных бесед.

Осознание и принятие студентами социально-профессиональной значимости поликультурных ценностей, наличие прочного интереса к 
иным культурам и стремление к межкультурному взаимодействию является мотивационно-ценностным критерием сформирвоанности поликультурной компетентности.

3) Деятельностно-поведенческим - активность и успешность (продуктивность) действий. Активность определяется объемом (интенсивностью) межкультурного взаимодействия (в общесоциальном либо профессиональном аспектах), уровнем инициативы и самостоятельности. По данному показателю личность может характеризоваться пассивностью (отсутствие инициативы, неучастие в межкультурном взаимодействии), вынужденной активностью (участие ситуативно и детерминировано внешними обстоятельствами, инициатива отсутствует) либо творческой активностью (внутренне мотивированное, добровольное участие в межкультурной коммуникации, проявление инициативы по организации межкультурного взаимодействия). Успешность действий определяется по степени достижения запланированных результатов межкультурного взаимодействия - от неудачных действий до действий, приводящих к полноценному достижению поставленных целей. Наиболее адекватным способом оценки рассматриваемой составляющей поликультурной компетентности является количественно-качественный анализ деятельности и поведения студентов, а также результатов предпринятых действий, осуществляемых посредством педагогического наблюдения и экспертной оценки.

Итак, активность студентов в межкультурном взаимодействии, культурная адекватность их поведения, успешность предпринимаемых действий определяет деятельностно-поведенческий критерий сформированности поликультурной компетентности будущих педагогов.

В зависимости от степени соответствия когнитивным, мотивационноценностным и деятельностно-поведенческим показателям и критериям, мы 
выделили следующие уровни сформированности поликультурной компетентности студентов:

1. Низкий уровень характеризуется: а) неосвоенностью большей части изучаемой информации (более 50\%), разрозненностью, поверхностностью и механичностью усвоенных знаний, затрудненностью воспроизведения или объяснения информации; б) умозрительное (теоретическое) принятие и не полное согласие с социальной значимостью поликультурных ценностей, их «отделенность» от личностных мотивов поведения и деятельности, отсутствие интереса к иным культурам и стремления к межкультурному взаимодействию; в) пассивность и отсутствие инициативы в межкультурных взаимодействиях, отсутствие позитивных результатов при вынужденном участии в межкультурных коммуникациях.

2. Среднему уровню соответствуют: а) знания, усвоенные в объеме от $50 \%$ до $75 \%$ от общего объема информации, частично систематизированные, осмысленные и принятые на уровне убеждений, легко воспроизводимые и объясняемые с позиции нескольких наук, входящих в круг междисциплинарной интеграции; б) признание социальной значимости поликультурных ценностей при затруднении их сопоставления с личностными ценностями, неустойчивый интерес к иным культурам и ситуативное стремление к межкультурным взаимодействиям; в) ситуативное участие в межкультурном взаимодействии, непостоянство в проявлении инициативы такого взаимодействия, неустойчивость позитивных результатов предпринятых действий.

3. Высокий уровень предполагает: а) системное, междисциплинарноинтегрированное освоение всей полноты знаний на уровне применения и творчества, характеризующиеся пониманием их связи с практической деятельностью, места и значения для решения жизненных и профессиональных задач; б) осознание поликультурных ценностей как личностно значимых для жизни в обществе и эффективной 
профессиональной деятельности; наличие прочных интересов к иным культурам и стремление к межкультурному взаимодействию; в) активное, внутренне детерминированное участие в межкультурном взаимодействии, проявление инициативы, устойчивое достижение запланированных позитивных результатов.

Отдельно мы выделяем негативное содержание поликультурной сферы личности, условно объединив его в отрицательный уровень поликультурной компетентности, характеризующийся: а) полной неосведомленностью о поликультурной стороне общества, б) неприятием поликультурных ценностей, нетолерантным отношением к иным культурам, нетерпимостью к культурным различиям, в) проявлением межкультурной нетерпимости в поведении и деятельности.

Поскольку требование технологичности образования обусловливает выделение в целостном педагогическом процессе, в том числе, и в процессе формирования поликультурной компетентности студентов, определенных этапов, связанных с закономерностями развития личности, ее конкретных качеств, то и уровни сформированности этих качеств, (а также содержание диагностических процедур), также должны соответствовать задачам определенной стадии, отражать целевые и процессуально-содержательные особенности этапов. Поэтому приведенные выше уровни носят методологический характер, отражая основания для оценки уровней сформированности поликультурной компетентности студентов на каждом этапе ее формирования. Разница в этапном содержании уровней заключается в контексте информации, ценностей и видов взаимодействия. При этом следует учитывать, что содержание высокого уровня, соответствующего последнему этапу, описывает поликультурную компетентность студентов во всей полноте ее общесоциального и профессионального контекста, а высокий уровень характеризует личность будущего педагога со сформированной поликультурной компетентностью. 


\section{3. ПСИХОЛОГО-ПЕДАГОГИЧЕСКИЕ УСЛОВИЯ ФОРМИРОВАНИЯ ПОЛИКУЛЬТУРНОЙ КОМПЕ ТЕНТНОСТИ БУДУЩИХ ПЕДАГОГОВ}

Концептуальные положения поликультурного образования, такие, как контекстность, диалогичность и деятельностный характер образовательного процесса, находят свое отражение в компетентностном подходе к профессиональной подготовке. К тому же, именно компетентностный подход непосредственно предназначен для решения задач, связанных с формированием компетентности - профессиональной, ключевой, базовой и т.п. Собственно, вид формируемой компетентности задает контекст, когнитивное содержание образования: информация, контекст учебной и профессиональной деятельности, решаемых учебных и учебно-практических задач и т.д.

С другой стороны, при организации поликультурной подготовки студентов необходимо учитывать особенности развития личности, тех ее качеств, которые включены в состав поликультурной компетентности. Эти особенности (закономерности, механизмы и т.д.) исследованы учеными, занимающимися вопросами поликультурного образования, поликультурной подготовки, аспектами формирования поликультурной компетентности разных социальных групп населения и т.д. Выявленные и апробированные ими психолого-педагогические, организационные, социальные и иные условия следует учитывать при проектировании процесса формирования поликультурной компетентности будущих педагогов.

Концептуальные основы (общефилософские подходы и принципы) организации поликультурного образования студентов обоснованы такими учеными, как: Н.В.Бордовская и А.А.Реан, И.В.Васютенкова, Т.Ю.Гурьянова, Г.Д.Дмитриев, О.В.Еремкина, Е.А.Нечаева, С.М.Федюнина и др. Анализ исследований показал, что к основным принципиальным положениям, 
обусловливающим целеполагание, отбор и структурирование содержания образования, выбор соответствующих средств и методов поликультурного образования традиционно относятся:

- отказ от монокультуризма и ориентация на открытость и диалог культур, культурный плюрализм, признание индивидуальных различий и учет культурных интересов представителей различных социальных групп, содействие культурной адаптации субъектов образования;

- опора на компетентностый подход в организации поликультурной подготовки педагогов, предполагающий освоение студентами навыков эффективного межкультурного взаимодействия, бесконфликтного общения и навыков конструктивного разрешения межкультурных конфликтов;

- учет индивидуального жизненного опыта учащихся, актуализация его позитивного поликультурного содержания и использование при отборе и структурировании содержания образования;

- системность поликультурной подготовки, обусловливающая системно-культурный подход к познанию окружающего мира и самого себя, взаимосвязанное использование многообразных образовательных средств и методов, содержания образования, а также учет двойственной природы человека: личности со своей индивидуальностью и социального (общественного) существа;

- культуроцентричность образования, предполагающая изучение культурных оснований жизни и деятельности современного человека, обращение к образцам разных культур, освоение различных способов и форм овладения культурой (комплементарность) [29,34,52,60,62,108,158].

Процессуально-содержательные особенности формирования поликультурной компетентности, организации поликультурного образования описываются через задачи и направления образовательной деятельности, закономерности и этапы поликультурного развития личности. Анализ исследований А.Г.Бермуса, О.В.Еремкиной, Т.Б.Менской, Е.А.Нечаевой, 
А.В.Шафриковой и др. свидетельствует о том, что к основным задачам воспитания в поликультурной среде, с которыми связаны определенные направления педагогической работы, относятся:

1) Моделирование содержания образования в двух аспектах:

- поиск и актуализация консолидирующих оснований, объединяющих идей, общечеловеческих ценностей в современной общественной практике и отражение их в содержании образования;

- выявление культурных смыслов, ментальной картины мира, архетипов культуры; воссоздание различных «образов культуры», образцов культуротворчества людей, воплощение и интеграция в образовательной среде различных культурных моделей, традиций, целей и ценностей, различных культурных установок, информационных кодов, способов познания окружающего мира;

2) Моделирование межкультурного взаимодействия в образовательном учреждении:

- стимулирование интереса к межкультурному взаимодействию, обеспечение ценностно-мотивирующего освоения личностью культуры во всем ее многообразии;

- обеспечение культурного диалога и внедрение неконфронтационных моделей развития и жизнетворчества, обеспечение «диалогичного» понимания культуры учащимися;

- организация многостороннего межкультурного диалога (администрация, коллеги, учащиеся, их родители), в том числе, установление партнерских отношений с родителями и семьями учащихся, с образовательными учреждениями и иными социальными институтами;

3) Организация системы мониторинга и управления поликультурным взаимодействием в образовательном учреждении, что предполагает: 
- овладение педагогами межкультурными технологиями, формами и методами работы с мультикультурным коллективом учащихся, основами поликультурного образования;

- разработку и освоение специалистами методов и способов диагностики и прогнозирования качества межкультурного взаимодействия в коллективе, тенденций его развития [19,62,103,108,178].

Конкретные средства, методы, приемы поликультурной подготовки учащихся, формы организации образовательного процесса обоснованы Л.Даниловой, А.Н.Джуринским, Н.В Бордовской и А.А.Реаном, Е.А.Нечаевой и другими учеными. При этом, как справедливо заметил А.Н.Джуринский, для поликультурной подготовки нет необходимости разрабатывать оригинальные педагогические формы и методы [58]. Практически все исследователи наиболее адекватными задачам поликультурного образования считают активные или интерактивные методы и формы организации образовательного процесса: диалогические и дискуссионные, моделирование, ролевые и деловые игры, метод проектов, тренинги межкультурного общения и пр. Важным является обеспечение соответствия выбранных форм и методов конкретным образовательным целям и задачам [29,55,58,108]. «Так, при социокультурной идентификации личности результативны исторические рассказы, изучение местных обычаев, этикета; при освоении понятий многокультурности - лекции, эвристические беседы, работа с источниками; при развитии навыков межкультурного общения - диалог и пр.» [58].

В работах А.Г.Бермуса, Т.Г.Грушевницкой, А.Н.Джуринского О.В.Еремкиной, И.А.Колесниковой, Е.А.Нечаевой и т.д. содержатся мнения и рекомендации относительно предметно-содержательных компонентов образовательного процесса поликультурной направленности. В частности, А.Н.Джуринский, отмечая, что к функциям поликультурного воспитания относится формирование у учащихся представлений о многообразии и 
взаимосвязи культур, позитивном значении этого многообразия для самореализации личности и воспитание положительного отношения к культурным различиям, развитие способностей к толерантному межкультурному взаимодействию, приводит следующие целевые ориентиры выбора содержания поликультурного воспитания:

- обеспечение социокультурной идентификации личности;

- содействие освоению учащимися системы понятий и представлений о поликультурной среде;

- воспитание положительного отношения учащихся к диверсифицированному культурному окружению;

- развитие навыков социального общения в поликультурной среде [58].

Автор называет важнейшим способом организации поликультурного воспитания контекстное изучение ряда учебных дисциплин, что позволяет «решать двойную задачу: стимулировать интерес детей к новому знанию и одновременно предлагать различные точки зрения на окружающий мир» [58]. Особое внимание, по мнению ученого, следует уделять культурологической направленности филологического образования (языковая подготовка), хотя поликультурализм должен пронизывать все предметы учебной программы: гуманитарного, эстетического, естественнонаучного циклов.

Аналогичного мнения придерживаются и другие исследователи, определяя интегративность и культурную (поликультурную) контекстность как основные условия отбора информационного содержания образования. Интегративность при этом предполагает интеграцию культурного (поликультурного) содержания, культурных образцов в целый ряд гуманитарных и специальных дисциплин [62]. В аспекте поликультурного содержания целесообразно проблемно-ориентированно рассматривать вопросы отечественной и зарубежной культуры, элементы профессиональной культуры и т.д. в соотнесении с содержанием конкретных учебных 
дисциплин, а источниками конструирования содержания образования могут служить предметные области гуманитарных и общественных наук, тексты, отражающие поликультурную специфику жизни в современном обществе и педагогической деятельности, содержание разных видов профессиональной деятельности, педагогических функций, выполнение которых предполагает межкультурное взаимодействие и т.д. [58,62,108].

А.Г.Бермусом описано так называемое проблемное поле межкультурного диалога, которое может рассматриваться в контексте конструирования содержания поликультурной подготовки студентов. Автор, проанализировав сущность и характер межэтнического общения, приводит основные причины затруднений, возникающих в мультикультурных коллективах, формулировку которых мы расширили и вывели за рамки национальной составляющей:

- представления о «наглости», «жестокости» или «неприличии» тех или иных культур,

- негативная оценка личности на основе ее идентификации с той или иной культурной общностью,

- необоснованная универсализация ценностей, идей и представлений, характерных для одной культуры, - до уровня общечеловеческой культуры,

- отсутствие чувствительности и понимания межкультурных различий, важности дифференциации поступков, их возможных культурных оснований и альтернативных оценок и др. [19].

Данная проблематика, на наш взгляд, может стать содержательной основой для учебно-практической подготовки студентов к взаимодействию в поликультурном обществе, в том числе, в профессиональном сообществе.

Поскольку профессиональная подготовка является этапом профессионализации личности, а профессионализация - одна из сторон социализации, то целесообразно рассмотреть становление поликультурной компетентности личности в терминах процесса социализации. 
Социальная компетентность личности формируется в процессе социализации, начиная с рождения. Усвоение культурных норм и ценностей общества, в том числе, поликультурных, осознание социальноэкономических, политических, этнических и др. реалий жизни, освоение социальных ролей происходит в условиях реального и виртуального социального взаимодействия. Общество воздействует на личность через ее ближайшее окружение (семью, друзей и знакомых, референтную группу) и средства массовой информации, прививая нормы и ценности, «обеспечивая» всем, что уже накоплено [108]. Если социализации осуществляется стихийно, без целенаправленного воспитательного сопровождения (семьи, педагогов, общественных и политических организаций (государства) и т.д.), то воспринимаемый социальный опыт, нормы и ценности общества, могут быть не вполне осознаны и не в полном объеме, избирательно интериоризированы личностью, что в дальнейшем может привести к асоциальным проявлениям в общении и поведении, в частности, к этническое, религиозной или расовой нетерпимости, культурной интолерантности и т.П.. А в случае, если у социализанта отсутствуют конструктивные примеры выполнения основных социальных ролей (отца/матери, друга, гражданина, учащегося, работника, мужа/жены) и, к тому же, нет возможности (или необходимости) самому осваивать эти роли, то, без специальных педагогических воздействий, в будущем он вряд ли будет способен к полноценной социальной самореализации. На наш взгляд, в контексте поликультурной подготовки студентов следует рассматривать освоение ими основных социальных ролей с позиции диалога культур: взаимодействие «старший-младший» (родительребенок), «взрослый-ребенок (подросток)», «этнос-этнос», «субкультуракультура», «мужчина-женщина» и т.п.

Это тем более справедливо для формирования профессионального компонента поликультурной компетентности. Кроме специальных знаний, умений и навыков, для качественного профессионального труда личности 
необходимо иметь представление о стандартах этого качества, иметь образцы для подражания. Это не всегда возможно, поскольку в повседневной жизни не каждый встречается с лучшими представителями педагогической профессии. Отсутствие эталонов профессионализма, примеров эффективного выполнения педагогических функций в поликультурном коллективе, недостаточность знаний о сущности и содержании данной стороны профессиональной деятельности и т.п. обусловливает неготовность молодых педагогов эффективно осуществлять поликультурное воспитание учащихся.

Согласно ролевой теории личности, личность есть функция от совокупности социальных ролей, которые человек выполняет в обществе, поэтому социализацию многие ученые рассматривают как процесс освоения человеком многообразных социальный ролей $[127,191]$. При целенаправленном обучении человека выполнению конкретных социальных ролей происходит усвоение соответствующих культурных (этнических, возрастных, гендерных, профессиональных и др.) норм, формируется адекватное ролевое поведение. С этих позиций социализация представляется как процесс обучения общепринятым способам и методам действий и взаимодействий, конструктивному ролевому поведению, в результате чего индивид становится действительно частью общества [61,136,139,159 и др.]. Данного мнения придерживается педагог Н.М.Таланчук, считающий, что жизнь каждого человека связана с выполнением системы социальных ролей, и доказывающий возможность воспитания социального поведения учащихся через актуализацию социальных ролей и микропроектирование педагогом элементов такого поведения [145]. Целенаправленное обучение школьников выполнению базовых социальных ролей в специально создаваемых ролевых проблемных ситуациях, при грамотном педагогическом моделировании контекста социальной жизни и деятельности учащихся, является целью и ядром его системно-ролевой теории воспитания личности [102,145]. Данный контекст 
включает и поликультурное содержание общественной жизни и профессиональной деятельности.

Ролевое обучение связано со следующими аспектами: наличием полноценной информации о сущности той или иной роли, ее значении и соответствующих ей нормах, причем важным является источник и способ передачи/получения информации (информационный аспект); стремлением человека выполнять данную роль, соответствовать ее нормам, ожиданиям общества, основанном на интересах и установках личности (мотивационный аспект); возможностью научиться исполнять роль, выполнять обязанности и осуществлять права в соответствии с конкретной ролью, что обеспечивается наличием ситуаций, обеспечивающих данную возможность (деятельностный аспект) [81,110,116,169 и др.].

О.Н.Мачехина в диссертационном исследовании социальную компетентность рассматривает как реализацию определенного ролевого задания, выполнение которого требует социальной подготовленности личности, приобретаемой (усваиваемой) в конкретных ситуациях в течение всей жизни. Автор обосновывает возможность целенаправленного развития компетентности через ролевое обучение на основе проектно-контекстного подхода. Данный подход, в авторской интерпретации, реализуется в ролево-игровых проектах, объединяющих ролевые игры и обучающие социальные ситуации как формы контекстного обучения и воспитания [102].

Таким образом, ролевая теория личности и базирующаяся на ней системно-ролевая теория воспитания актуализируют следующие условия формирования поликультурной компетентности студентов: наличие полноценной систематизированной информации о поликультурной сущности и значении разнообразных социальных ролей и профессиональных функций и обеспечение ее прочного усвоения студентами; организация установочных мотивационных воздействий на учащихся с целью сознательного позитивного освоения ими социальных ролей и профессиональных функций, 
с учетом поликультурности социального и профессионального окружения; отражение поликультурного контекста социальной и профессиональной действительности посредством создания соответствующих ролевых и деловых ситуаций (ролевых и деловых игр), в которых возможно овладение адекватными способами и стратегиями поведения, общения, деятельности.

Суть компетентностного подхода к профессиональной подготовке такова, что позволяет реализовать все вышеназванные условия системно, с применением наиболее адекватных, с точки зрения сущности компетентности как качества личности, средств, методов и форм организации учебно-воспитательного процесса. 


\section{4. КОМПЕТЕНТНОСТНЫЙ ПОДХОД КАК ОСНОВА ОРГАНИЗАЦИИ ПОЛИКУЛЬТУРНОЙ ПОДГОТОВКИ БУДУЩИХ ПЕДАГОГОВ}

Сущность компетентностного подхода заключается в приоритетной ориентации на такие цели - векторы образования, как обучаемость, самоопределение (самодетерминация), самоактуализация, социализация и развитие индивидуальности [63]. Выбор инструментальных средств достижения этих целей определяется новыми метаобразовательными конструктами: компетентностями, компетенциями и метакачествами [63], то есть, конкретное когнитивно-информационное и методико-технологическое наполнение образовательного процесса обусловливается сущностью формируемого качества личности - компетентности.

В.А.Исаев отмечает, что с позиции компетентностного подхода формирование профессиональной компетентности является целеполагающим и осуществляется исключительно за счет методических и педагогических подходов, а не за счет «преподавания» на предметно-содержательном уровне. Для этого предусматривается необходимость соответствующей организации образовательного процесса, а именно:

1. Изменение роли преподавателя: от трансляции знаний и способов деятельности к проектированию индивидуального личностного развития каждого студента.

2. Внедрение инновационных методов стимулирования учебной деятельности посредством действия, обмена опытом, изучения опыта, постановки и творческого решения проблем.

3. Применение методов обучения, содействующих формированию всех составляющих профессиональной компетентности учащихся в зависимости от их личных склонностей. Основными используемыми методами являются: метод позитивного совершения ошибок, творчески-проблемный, игровые 
методы, исследование ролевых моделей, социальное взаимодействие, презентация идей, метод проектов. При этом метод проектов рассматривается здесь в качестве основного дидактического средства.

4. Ориентация студентов на бесконечное разнообразие профессиональных и жизненных ситуаций, обеспечение прочной взаимосвязи образовательных целей с ситуациями применимости на рынке труда.

5. Применение альтернативных оценочных процедур, адекватных особенностям приобретаемого студентами опыта - набору компетенций, и учитывающих индивидуальные особенности развития [67].

И.А.Зимняя, анализируя сущность компетентностного подхода к образованию, приводит следующие его характеристики:

- c позиций концепции четырехуровневости методологического анализа И.В. Блауберга, Э.Г. Юдина, компетентностный подход относится к третьему уровню - уровню конкретной науки, или куста наук (в данном случае - к образованию, наряду с аксиологическим, контекстным и др.) и определяет результативно-целевую направленность образования [24];

- отражая признаки первых двух предыдущих уровней методологического анализа, компетентностный подход является системным, междисциплинарным, характеризуется и личностным и деятельностным аспектами, т.е. имеет и практическую, и гуманистическую направленность, усиливает собственно практико-ориентированность образования, его прагматический, предметно-профессиональный аспект [143].

- конкретно-научные характеристики компетентностного подхода к образованию проявляются в интеграции таких научно-методологических оснований, как: а) потенциально-актуальный, комплексный подход, в рамках которого содержание компетенций задает некий образ, программу, а компетентность характеризует степень индивидуального соответствия человека этому идеалу (в понимании Н. Хомского, [170]); б) личностно- 
деятельностный подход как гуманистическая основа процесса формирования компетентности, предусматривающий гармоничное сочетание конкретных образовательных целей (формирование компетентностей) и глобальную цель - природосообразное ненасильственное развитие и саморазвитие личности; в) ситуационно-проблемный подход, отражающий особенности организационно - управленческой формы образования, нацеленного на формирование компетентности личности, а именно: создание учебных ситуаций различных уровней проблемности и разного контекста; г) задачный подход (в общем контексте работ Г.А. Балла, Л.М. Фридмана, Е.И. Машбица, М.Г. Дзугкоевой), предполагающий предварительное моделирование педагогом иерархии позиционно-ролевых задач, включающих решение проблем социального и профессионального взаимодействия, коммуникативного оформления образовательного процесса, и направленных на обеспечение реализации студентами компетентностей, функциональный подход [65,66].

Э.Ф.Зеер отмечает, что центральное место в реализации компетентностного подхода принадлежит ряду развивающих технологий, а именно: - когнитивно ориентированным (диалогические методы обучения, семинары-дискуссии, проблемное обучение, когнитивное инструктирование, когнитивные карты, инструментально-логический тренинг, тренинг рефлексии и др.); - деятельностно ориентированным (метод проектов, имитационно-игровое моделирование, организационно-деятельностные игры, контекстность обучения и др.); - личностно ориентированным (интерактивные и имитационные игры, тренинги развития, развивающая психодиагностика и др.) [62,63].

Исходя из нашего видения сущности поликультурной компетентности педагога системной совокупности общесоциальных и профессиональных характеристик, можно сказать, что компетентностный подход к образованию должен способствовать оптимизации освоения и исполнения учащимися 
разнообразных социальных и профессиональных ролей, обеспечивать способность к реализации многообразных социальных и профессиональных ролевых функций в условиях поликультурного общества. Это, в свою очередь, предполагает ориентацию компетентностного подхода на овладение студентами контекстной поликультурной информацией и творческими способами ее использования, на их ориентацию в многообразии межкультурных коммуникативных ситуаций социальной и профессиональной действительности и развитие умений адекватно действовать в меняющихся обстоятельствах.

Структурирование поликультурной компетентности обусловливает выбор в рамках компетентностного подхода средств, методов и приемов, обеспечивающих эффективное формирование у студентов системы социальных и профессиональных поликультурных знаний и умений, развитие ценностной мотивации к поликультурному взаимодействию, становления социального и профессионального опыта межкультурной коммуникации и поликультурного воспитания.

Целенаправленное развитие социальной и профессиональной компетентности в процессе профессиональной подготовки связано: а) с определенным содержательным и процессуальным структурированием и наполнением содержания обучения с целью обеспечения целостности, внутрипредметной и межпредметной интеграции научного знания, рационального сочетания вариативности и инвариантности информации, ее фундаментальности и контекстности б) с выбором и реализацией эффективных форм и методов организации деятельности студентов по системному овладению социальными и профессиональными знаниями, их сознательному творческому применению, овладению навыками профессиональной деятельности, социального поведения, социального и профессионального общения, в) с организацией конструктивного педагогического взаимодействия, способствующего развитию сознательного 
отношения учащихся к содержанию образования, ответственного отношения к своей деятельности и поведению, повышению их образовательной активности и т.д.

Охарактеризуем компетентностный подход с точки зрения его основного методико-технологического содержания определяющего выбор конкретных форм, средств, методов и содержания обучения и воспитания. Заметим, что опора на базовые метапринципы компетентностго подхода к профессиональной подготовке (системность, контекстность, вариативность, активность, личностно-деятельностная ориентированность и ситуационнопроблемная организация образования, положения функционального и задачного подходов) обеспечивает развивающий характер образования.

Функциональный подход тесно связан с ролевой теорией личности и концепцией ролевого обучения. Сознательная деятельность человека связана с реализацией конкретных функций - атрибутов той или иной социальной или профессиональной роли. Функция - это нечто, способствующее адаптации общества или индивида к своей среде. Все стороны духовной и социальной жизни (в том числе, предметно-практическая деятельность и межличностное взаимодействие в поликультурной среде) функциональны и предполагают достижение определенных результатов, соответствующих потребностям личности и/или общества [176]. Функциональный подход в данном контексте предполагает выделение и анализ функций, соответствующих определенной социальной (гражданин, друг, родитель и т.д.) или профессиональной (в нашем случае - учитель физической культуры, тренер, организатор физкультурно-рекреационной деятельности и т.д.) роли, определение их назначения и освоение действий (программ, алгоритмов, видов деятельности) по реализации этих функций. «Функциональный подход дает возможность ввести учащегося в мир реальных потребностей, для удовлетворения которых были созданы конкретные объекты», в частности, 
профессии как исторически сложившиеся общественно необходимые виды деятельности [180].

В контексте общесоциального содержания поликультурной компетентности мы будем рассматривать роль гражданина поликультурного общества. В соответствии с выделенными видами субкультур эта роль предполагает исполнение функций участника / организатора межэтнического взаимодействия, участника / организатора межличностных взаимодействий с представителями разных возрастных и гендерных групп (культур), различных молодежных субкультур функций сбора, приема и передачи поликультурной информации, а также функций поликультурного саморазвития.

В контексте профессионального содержания компетентности мы выделяем роли: - «коллега» (функции участника / организатора процесса обмена педагогическим опытом), - «организатор взаимодействия с родителями учащихся» (функции анализа и выявления культурных характеристик семьи, организации педагогического взаимопонимания с носителями разных культурных ценностей, привлечения родителей к решению педагогических задач), - «организатор поликультурного воспитания учащихся» (функции анализа и выявления культурных особенностей учащихся, организации межкультурного взаимодействия учащихся, когнитивной, мотивационно-ценностной и поведенческой подготовки учащихся к жизни в поликультурном обществе).

Контекстность, как концептуальное условие формирования компетентности, предусматривает отражение в содержании образования (и информационной, и коммуникативной, и деятельностной его частях) сущностных характеристик изучаемых профессиональных или социальных явлений, процессов, в нашем случае - поликультурных характеристик.

А.А.Вербицкий, основоположник концепции контекстного обучения, сущность последнего видит в том, что в формах организации образовательной деятельности динамически моделируется общекультурное, 
духовное, предметное, социальное и образовательное содержание жизнедеятельности учащихся, осуществляется переход его учебнопознавательной деятельности в социально-практическую [39]. «Основной единицей содержания контекстного обучения и воспитания является ситуация во всей ее предметной и социальной неоднозначности и противоречивости, а формами организации деятельности учащихся являются коллективная (совместная), групповая, парная, индивидуальная при ведущей роли коллективной. Из них составляются конкретные формы в зависимости от текущих целей, содержания и условий образовательной деятельности» [102, c.15].

Большой мотивационный потенциал данного подхода обусловлен тем, что источником содержания образования является поликультурное содержание реальной социальной и/или профессиональной жизнедеятельности, а также объективной востребованностью развиваемых качеств, формируемых умений и навыков.

$\underline{\text { Интеграционные }}$ процессы в образовании отвечают положениям личностно-ориентированной $\quad$ парадигмы $\quad[86,96,154,160,174 \quad$ и $\quad$ др.]. Интеграция (лат. integratio - полный, цельный) - процесс и результат создания неразрывно связанного, единого и цельного - в обучении осуществляется несколькими способами. Во-первых, путем объединения в одном синтезированном курсе (теме, разделе, программе) элементов разных учебных предметов, суммирования основ разных наук в раскрытии межпредметных проблем (как в случае с появлением учебного предмета «Основы современного естествознания») [96]. Во-вторых, как акцентирование внимания на характеристиках одного и того же явления при изучении разных дисциплин, что не требует разработки специальных учебных курсов.

Междисциплинарная интеграция информации - суть междисциплинарного интегративного подхода - обеспечивает системность 
теоретических знаний, всестороннее видение и осознание сложных явлений и процессов социальной и профессиональной реальности, формирование целостного представления о конкретном предмете, явлении, виде деятельности. Она осуществляется путем группировки вокруг базовой дисциплины (интегратора, ядра интеграции) информации (научных понятий, законов, сведений и т.д.) из разных научных дисциплин, в которых ряд тематических вопросов рассматривается с точки зрения объекта, предмета и задач науки-интегратора. В качестве такого ядра может выбираться та научная область, в которой изначально (или наиболее полно, сущностно) определяется понятие - предмет интегрированного рассмотрения.

Интегративный подход актуализирует и интегративный тип познания, сочетающий непосредственный опыт, системное мышление, продуктивный подход к проблеме, и предполагающий познание целого не только на базе изучения его отдельных частей, но и выявления взаимосвязей между ними [160]. Деятельность студентов по структурированию и систематизации интегративных знаний «предполагает мыслительную деятельность учащихся по установлению удаленных связей между отдельными понятиями, объектами» [86]. Ее организация возможна посредством применения на теоретических занятиях приемов мнемической деятельности, на практических - проектных методов обучения.

Коммуникативный аспект компетентности (мотивационнорегулятивные основы накопления опыта межкультурного общения) получает свое развитие при опоре на интерактивный подход в образовании. Он представляет собой наиболее современную форму активных методов обучения, основанных на положениях коммуникативного подхода. Интерактивные методы обучения ориентированы на «широкое взаимодействие обучающихся не только с преподавателем, но и друг с другом, на доминирование активности обучающихся и на активизацию внутреннего диалога (экзистенциального переживания обучающимися 
учебного материала)» [28, с.18]. Роль преподавателя заключается в направлении и поддержании активности студентов в межкультурной коммуникации, выявлении многообразия точек зрения, облегчении взаимопонимания участников общения, побуждении их к внутреннему диалогу; он выполняет функции консультанта-фасилитатора (помощника), а не эксперта и своеобразного информационного «фильтра» [28].

Формами интерактивной организации учебного процесса являются социо- и психодрама, учебная, деловая и ролевая игра, дискуссия; интерактивность достигается путем применения приемов стимулирования рефлексии, побуждения к эмпатическому осмысливанию ситуаций межкультурного общения, обращения к витагенному опыту участников взаимодействия, обоснованию объективного смысла и личностной значимости конкретных ситуаций, явлений, процессов, диалогичности (полилогичности) обучения.

Реализация положений теории ролевого обучения и функционального подхода, а также принципов контекстности, интегративности и интерактивности образования возможна при ситуационно-проблемной и задачной организации образовательного процесса.

Ситуационно-проблемная организация поликультурного образовательного процесса предполагает создание учебных коммуникативных ситуаций различной степени проблемности и различного контекста (социального, профессионального, конкретного ролевого или функционального). Основой такой организации является ситуационный подход, суть которого состоит в том, что познаваемое событие, обстановка анализируются с точки зрения ситуаций, их составляющих [16].

С точки зрения дидактики ситуационный подход представляет собой одну из разновидностей проблемного обучения, «суть которого в общих чертах может быть сведена к выработке у студентов приемов 
самостоятельного исследования и решения поставленных нестереотипных задач» [43].

Ситуационное моделирование (или метод решения ситуационных задач) как метод обучения студентов применим и на теоретических, и на практических занятиях. Основными формами его реализации являются ситуации-иллюстрации (используются в ходе изложения лекционного материала с целью пояснения отдельных теоретических положений), ситуации-оценки (анализ и оценка студентами описанной преподавателем контекстной ситуации), ситуации-упражнения и ситуации-проблемы (анализ ситуации и выбор способа ее разрешения), ролевые ситуационные игры $[43,175]$.

Центральным понятием проблемного обучения является проблемная ситуация, которая понимается как наличие и осознание того или иного противоречия в изучаемом процессе, явлении. На основе анализа проблемная ситуация преобразуется в проблемную задачу, требующую найти способ объяснения и разрешения противоречия. То есть, проблемный метод обучения предполагает последующиее шаги: проблемная ситуация, проблемная задача, модель поиска решения, решение [90,101,107,142,175 и др.].

Разрешение проблемных ситуаций способствует эффективному развитию мышления, поскольку актуализирует различные способы умственных действий. В частности, согласно классификации В.В.Давыдова, при разрешении проблемных ситуаций, возникающих как реакция на противоречие между теоретической возможностью решения задачи и практической неосуществимостью либо нецелесообразностью известного способа решения, требуется системный анализ и синтез методов и средств деятельности. Проблемная ситуация, возникающая при осознании противоречия между имеющимися знаниями, умениями и навыками и требованиями решаемой задачи, актуализирует системный анализ и синтез 
знаний и умений; при решении ситуаций, вызванных новизной условий, в которых должны использоваться имеющиеся знания, либо противоречием между многообразием имеющихся способов, путей решения и необходимостью выбрать один из них, развиваются такие СУДы, как абстрагирование, конкретизация и варьирование [107].

Одним из способов реализации ситуационно-проблемного подхода к обучению является задачная форма организации образовательного процесса, предполагающая разработку конкретных задач, направленных на разрешение контекстной проблемной ситуации профессионального или социального взаимодействия. Задачи могут быть связаны с поиском и обработкой информации, с освоением способов применения знаний для решения практических проблем, разработкой стратегии деятельности, выбором средств реализации определенной социальной роли или профессиональной функции и т.п. [85].

А.Х.Курашинова выделяет группы задач, способствующих развитию профессионального мышления педагога, которые мы интерпретировали более широко: - информационно-аналитические (задачи, направленные на формирование знаний студентов в области стратегии поликультурной деятельности, поведения, общения); - аналитико-синтетические (задачи, связанные с формированием знаний и умений студентов выделять, анализировать и исследовать свойства поликультурных систем (общесосоциальных профессиональных контекстных ситуаций поликультурного общения, деятельности, поведения, социальных ролей, профессиональных функций и т.д.); - проектно-конструкторские (задачи, связанные с формированием умений студентов разрабатывать индивидуальные проекты процесса общесоциальной и профессиональной поликультурной деятельности, общения, поведения); - организационноподготовительные (задачи, направленные на освоение способов планирования и организации индивидуального и коллективного 
общесоциального и профессионального межкультурного взаимодействия); операционно-практические (задачи, направленные на формирование оценочных суждений, коррекцию процесса и результата поликультурной деятельности, поведения, общения) [85]. В целом, все задачи можно разделить на три основных группы:

1) задачи, связанные с анализом и оценкой ситуации, поиском и обработкой информации,

2) задачи, связанные с выбором способов действий, преобразованием ситуации,

3) задачи, связанные с анализом результатов действий, контролем и коррекцией поведения и деятельности [62,85,154].

Обобщив мнения А.Г.Бермуса, В.В.Давыдова, О.В.Еремкиной, А.Х.Курамшиновой, С.Д.Неверковича, Ю.С.Тюнникова и других ученых, мы сочли возможным использовать специально разработанные контекстные ситуационно-проблемные задачи в образовательном процессе, направленном на формирование поликультурной компетентности будущих педагогов, классифицировав их по основанию осваиваемых различных функций атрибутов социальных и профессиональных ролей. Для этого каждой ролевой функции необходимо поставить в соответствие типичные ситуации межкультурного взаимодействия, подобрать примеры возможных в этих ситуациях проблем и предложить студентам задачи, направленные на разрешение описанных ситуационных проблем. Например, находясь в роли гражданина поликультурного общества, реализуя функции участника межэтнического взаимодействия в ситуации обсуждения тех или иных вопросов политического, социально-экономического, духовного развития общества. В данном случае могут возникнуть проблемы, обусловленные противоречием между многообразием взглядов на жизненные цели, экзестенциальные ценности, присущих разным национальным культурам, и необходимостью достигнуть конценсусса. Подготовиться к адекватным и 
эффективным действиям в подобном случае поможет решение студентами такой задачи: определить, какие различия во мнениях связаны с этнокультурными особенностями участников взаимодействия; проанализировать соответствующие народные ценности, традиции и установки; найти точки соприкосновения, выявить общее ядро, общий смысл данных установок; соотнести традиции с современностью; сделать вывод.

Решение учебных задач может и ограничиваться рамками учебного занятия, и включать самостоятельную подготовку, а также предполагать разработку разных по форме представления проектов, соответствующих содержанию задачи и описывающих способ разрешения заложенной в ней проблемной ситуации. По виду деятельности и форме представления результатов различают:

- конструктивно-практические проекты, например, дневник наблюдений, создание игры и её описание;

- игровые - ролевые проекты, например, разыгрывание фрагментов профессиональной деятельности / социального взаимодействия;

- информативно-исследовательские проекты на определенную профессиональную либо социальную тему;

- сценарные проекты - сценарий мероприятия, связанного с культурным обменом;

- творческие работы - свободное литературное сочинение, описание решения какой-либо проблемы, размышление на профессиональную тему [31,70,79,95,121,152,183,184 и др.].

Понятия «противоречие» и «проблема» находят свое отражение, в том числе, в технологиях активного обучения, а деловые и ролевые игры могут рассматриваться как формы реализации принципов активности и проблемности в обучении $[167,175]$.

Под технологией активного обучения (ТАО) понимается такая организация учебного процесса, при котором все учащиеся с 
необходимостью вовлекаются в учебно-познавательную деятельность, поскольку каждый либо имеет определенное ролевое задание, о выполнении которого он будет должен отчитаться, либо от эффективности его работы напрямую зависит качество выполнения коллективного задания [13,76,175 и др.].

Н.В.Борисова и Д.В.Чернилевский в своей классификации технологий активного обучения выделяют: неимитационные технологии (формы организации: проблемная лекция, семинар-дискуссия, «мозговой штурм», экскурсия и т.п), имитационные технологии -игровые (разыгрывание ролей (деловые и ролевые игры), дидактические игры, имитационный тренинг, стажировку с выполнением должностной роли) и неигровые (создание, анализ и разрешение конкретных ситуаций, связанных с решением контекстных задач, нравственным выбором; к ним относятся ситуациипроблемы, ситуации-оценки, ситуации-иллюстрации и ситуацииупражнения и т.п.) [175].

«Деловая игра -метод имитации ситуаций, моделирующих профессиональную ... деятельность путем игры по заданным правилам» [76, с.226], жестко задаваемые правила определяются содержанием выбранной деятельности. Это форма воссоздания предметного и социального содержания реальной профессиональной деятельности, в которой воспроизводятся и профессиональная обстановка, и профессиональные проблемы, ситуации, наиболее типичные и обобщенные для конкретной специальности [140].

Ролевая игра представляет собой моделирование ситуаций, в основе которых лежат проблемы взаимоотношений в коллективе, совершенствования стиля и способов руководства, коллективного взаимодействия. В процессе ролевой игры имитируются профессиональные или иные социальные отношения между представителями той или иной группы людей. 
Общим является то, что в основе их организации лежит та или иная игровая ситуация. Моделироваться могут и жизненные ситуации или условия взаимодействия людей в процессе той или иной деятельности, и хозяйственно-экономические отношения. «Элементы игры могут быть введены в любой метод и в любую форму обучения как часть целого. Игра может выступать как основная форма учебного процесса» [76, с.214].

Для подготовки к проведению полномасштабных деловых и ролевых игр служат имитационные упражнения (Басова Н.В.) или имитационные тренинги (Чернилевский Д.В.), меньшие по объему и количеству решаемых задач. Целью их проведения является предоставление учащимся возможности в непринужденной, творческой обстановке закрепить те или иные навыки и акцентировать внимание на определенном, достаточно важном понятии, категории, законе. Деятельность, организованная в форме имитационного упражнения (тренинга), предполагает отработку некоторых специализированных, конкретных навыков и умений; имитируется в этом случае некоторая достаточно узкая ситуация профессиональной деятельности или социального общения [175].

В процессе ролевой и деловой игры могут осваиваться и нормы профессиональных действий, и профессиональные отношения, а также нормы и ценности социального поведения и общения. Основным требованием к содержанию деловой игры является контекстность (А.А.Вербицкий) или прикладность (В.А.Парфенов). В их процессе (при формировании поликультурной компетентности будущих педагогов) могут разрешаться, например, следующие задачи: разработка сценария воспитательного мероприятия поликультурной направленности; организация обмена профессиональным или этнокультурным опытом; освоение традиционных и разработка новых форм и методов поликультурного воспитания учащихся, способов решения педагогических задач, связанных межкультурными проблемами и т.д. 
По форме деловые игры могут протекать как имитация прессконференции или научно-практической конференции, «круглого стола», тренировочного занятия, урока физической культуры, спортивного мероприятия и т.п. Ролевые игры могут имитировать ситуации межличностного общения, социального и профессионального межкультурного взаимодействия и т.п. [167].

Форма организации деловой игры должна соответствовать ее целям, в нашем случае - содержанию того вида опыта межкультурного взаимодействия, для освоения которого она предназначается. Особенно эффективной является деловая игра, сюжет которой строится как процесс разработки и принятия управленческого решения. Технология принятия управленческого решения является достаточно стандартной процедурой, что позволяет не разрабатывать новые деловые игры для формирования каждого типа опыта, но модифицировать единожды разработанную, наполняя ее соответствующими содержанием. Кроме того, этапы принятия управленческого решения соответствуют по основным шагам процессу творческого мыслительного действия [166], поэтому сам характер подобной игры предполагает развитие у ее участников творческих характеристик мышления.

Общая структура деловых и ролевых игр, построенных в форме принятия управленческого решения:

1. Подумайте, какие проблемные ситуации могут возникнуть в процессе межкультурного взаимодействия. Выберите одну из них для дальнейшей работы.

2. Предложите максимальное количество возможных вариантов решения проблемы.

3. Оцените возможные положительные и отрицательные последствия принятия каждого из предложенных вариантов. 
4. Подберите критерии оценки эффективности принятого решения.

5. По подобранным критериям выберите оптимальный вариант решения проблемы.

6. Обоснуйте свой выбор.

Для наполнения деловой / ролевой игры конкретным содержанием подбираются проблемные ситуации, соответствующие конкретной профессионально-педагогической функции, конкретной ситуации социального взаимодействия или социальной роли [167].

Деловые и ролевые игры в образовательном процессе могут выполнять роль специфических тренингов, способствующих становлению у студентов социального и профессионального опыта межкультурного взаимодействия.

Изложенное контекстное содержание компетентностного подхода к профессиональной подготовке подтверждает наше мнение о правомочности использования данного подхода для формирования поликультурной компетентности будущих педагогов.

При непосредственной организации поликультурного образования педагогов следует учитывать и использовать те методы и приемы, которые в наибольшей степени подходят для последовательного формирования системы знаний, становления ценностных отношений, развития поведения и деятельности, а также соответствуют содержательным аспектам формируемого блока поликультурной компетентности. То есть, необходимо опираться на закономерности развития когнитивной, мотивационноценностной и деятельностно-поведенческой сфер личности, постепенно повышая требования к уровню самостоятельности и продуктивности деятельности, к степени обобщения знаний и умений, а также осознанности и интериоризированности ценностей и мотивов.

Так, формирование полноценной системы поликультурных знаний, соответствующей нашим требованиям к уровню развития когнитивного компонента, развивается от эмпирического накопления поликультурных 
фактов через их культурологическое обобщение и далее - к интерпретации в соответствии с конкретными ситуациями общесоциального или профессионального межкультурного взаимодействия [62]. Формирование гуманистических ценностных отношений и основанных на них мотивов поведения и деятельности осуществляется через процессы осознания и усвоения ценностей, их интериоризации и верификации (соотнесения с собственным жизненным опытом), экстериоризации ценностей в мотивах поведения и деятельности [40,76,109,130,165 и др.]. Развитие деятельности может осуществляться как повышение степени ее самостоятельности, инициативности, сложности.

Не останавливаясь пока на данном вопросе подробно, отметим, что к наиболее эффективным методами и приемам организации поликультурной подготовки студентов, (в соответствии со структурными компонентами поликультурной компетентности и закономерностями их развития), мы отнесли: приемы мнемической деятельности, методы и приемы витагенного образования, приемы эмоционального воздействия, разъяснительные и дискуссионные методы и др. Организация образовательного процесса, в соответствии с сущностью компетентностного подхода, предполагает преимущественное использование проектных, тренинговых и игровых форм обучения и воспитания; а в соответствии с сущностью поликультурной компетентности - организацию культурных и общественных мероприятий, предполагающих межкультурное взаимодействие участников. 


\section{5. ОРГАНИЗАЦИЯ ОБРАЗОВАТЕЛЬНОГО ПРОЦЕССА В ВУЗЕ, НАПРАВЛЕННОГО НА ФОРМИРОВАНИЕ ПОЛИКУЛЬТУРНОЙ КОМПЕТЕНТНОСТИ БУДУЩИХ ПЕДАГОГОВ}

Теоретические и методологические основы поликультурного образования, поликультурной подготовки будущих специалистов, формирования поликультурной компетентности, содержание компетентностного подхода к профессиональной подготовке позволяют выделить совокупность психолого-педагогических условий формирования поликультурной компетентности будущих педагогов (таблица 3).

Таблица 3

\section{Психолого-педагогические условия формирования поликультурной компетентности будущих педагогов}

\begin{tabular}{|c|c|c|}
\hline № & $\begin{array}{c}\text { Общие условия формирования } \\
\text { поликультурной } \\
\text { компетентности }\end{array}$ & $\begin{array}{c}\text { Конкретизация и дополнение общих условий } \\
\text { в соответствии с особенностями развития } \\
\text { содержательных и структурных компонентов } \\
\text { поликультурной компетентности }\end{array}$ \\
\hline 1 & 2 & 3 \\
\hline 1. & $\begin{array}{lr}\text { Опора на основные положения } \\
\text { теории } \\
\text { образования: } \\
\text { культурный плюрализм, диалог } \\
\begin{array}{l}\text { культур, } \\
\text { деятельностное } \\
\text { культуры. }\end{array} \\
\text { контекстность, } \\
\text { освоение }\end{array}$ & 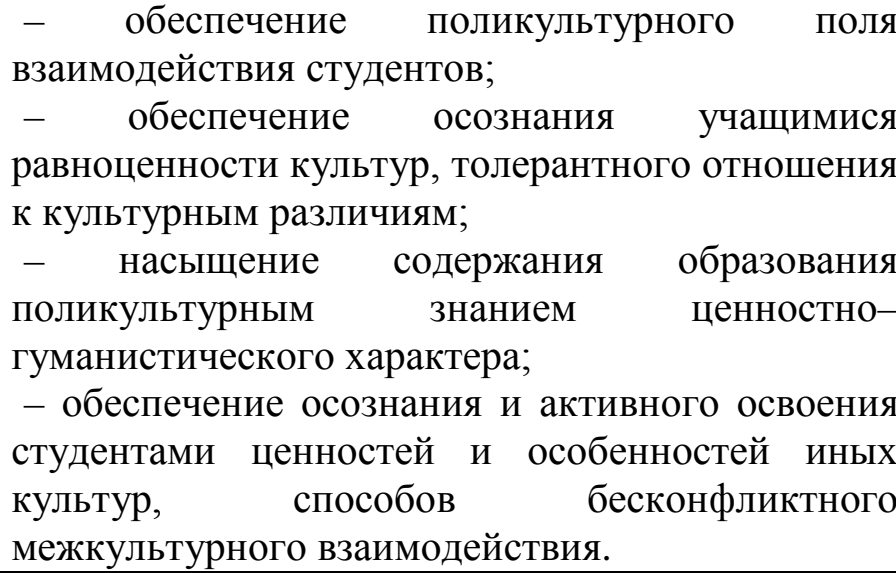 \\
\hline
\end{tabular}


Продолюение таблицы 3

\begin{tabular}{|c|c|c|}
\hline 1 & 2 & 3 \\
\hline 2. & 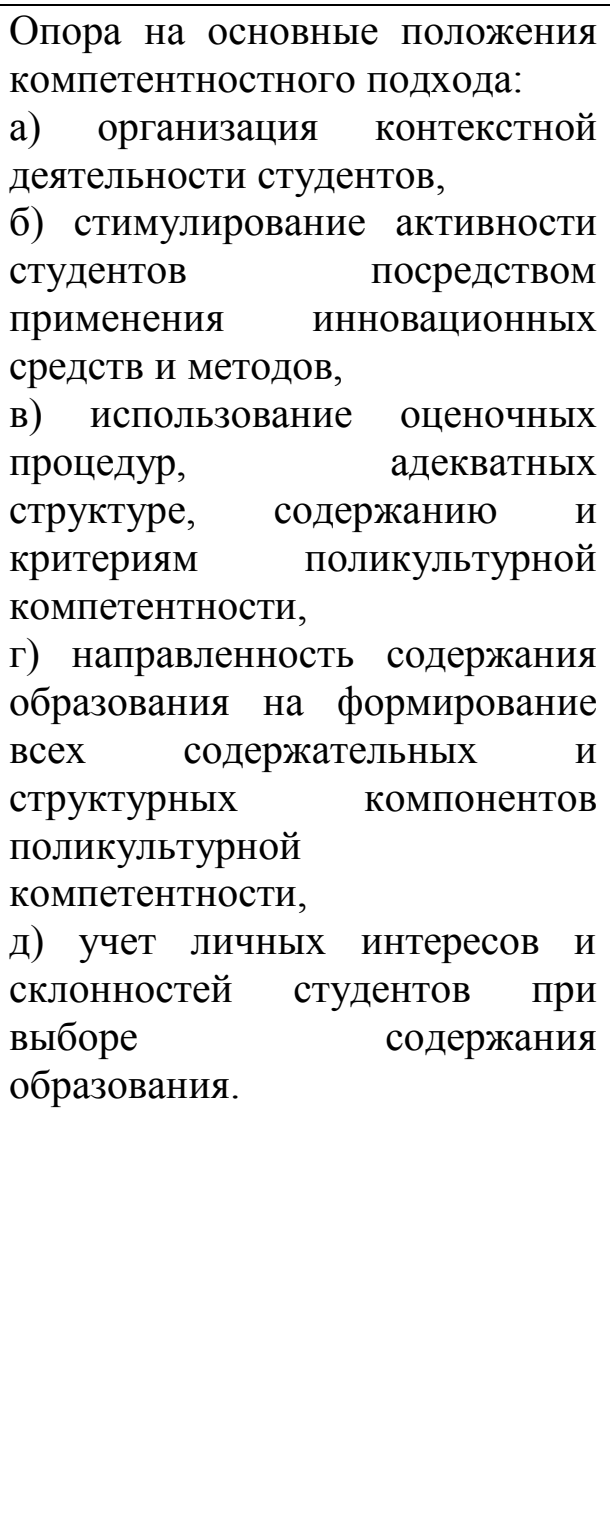 & 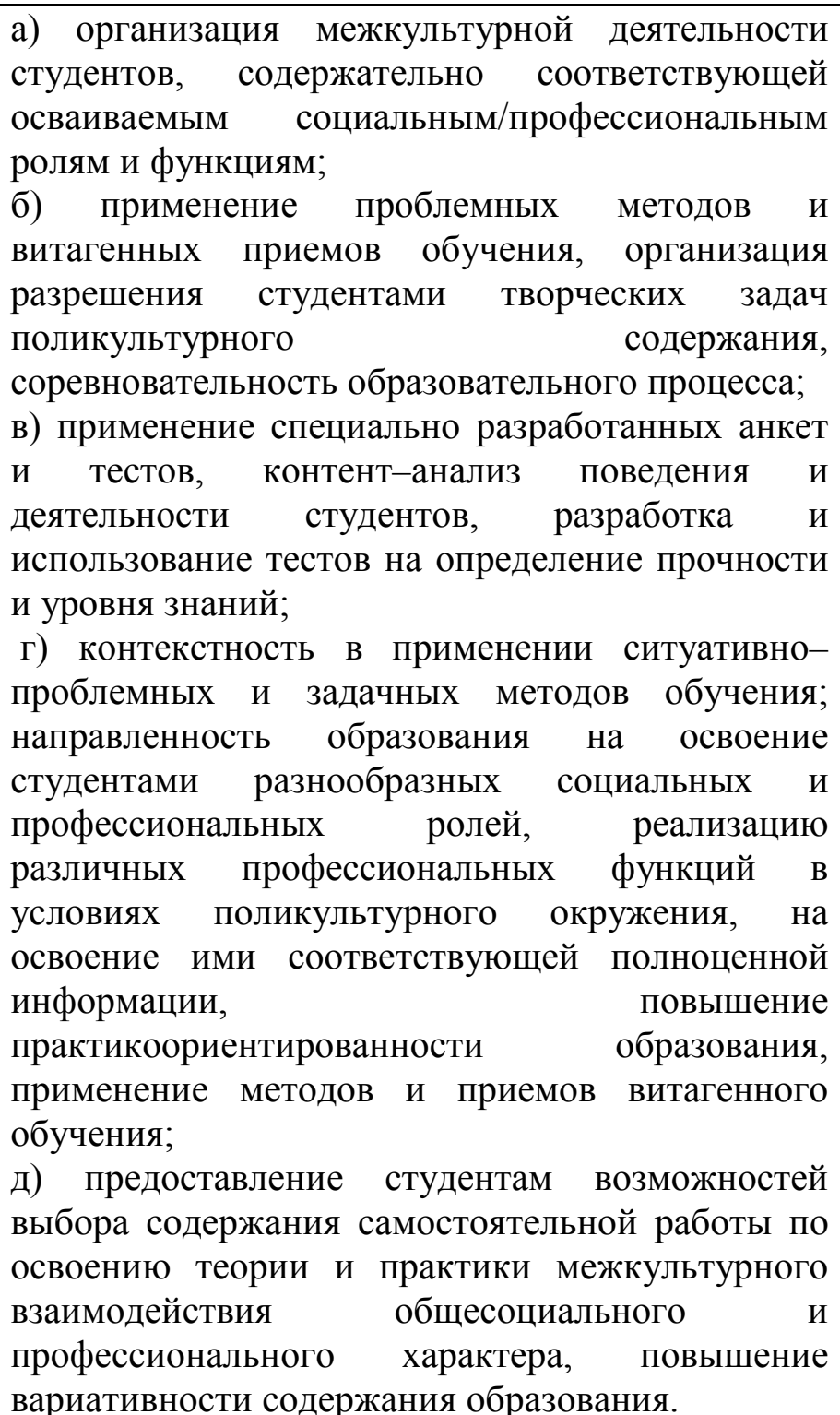 \\
\hline 3. & $\begin{array}{l}\text { Выбор средств, методов, форм } \\
\text { образования, соответствующих } \\
\text { методологическим } \\
\text { характеристикам } \\
\text { компетентностного подхода: } \\
\text { - активно - деятельностная } \\
\text { направленность образования, } \\
\text { - ситуативно-проблемная } \\
\text { организация образовательного } \\
\text { процесса, } \\
\text { - конструирование содержания } \\
\text { образования в соответствии с } \\
\text { идеями задачного } \\
\text { функционального подходов к } \\
\text { образованию. }\end{array}$ & 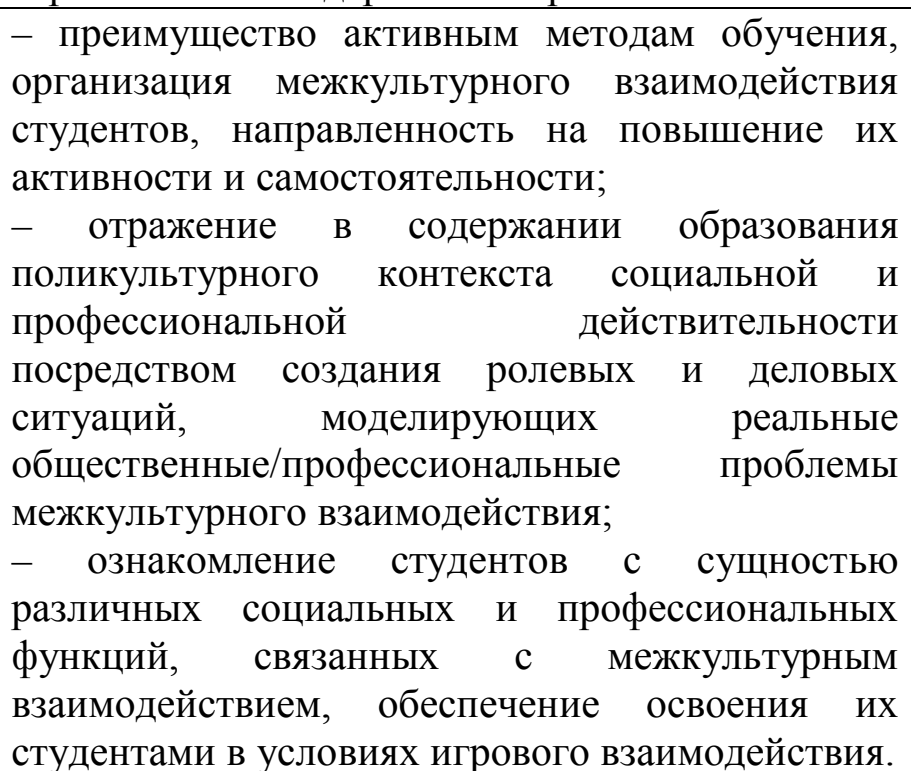 \\
\hline
\end{tabular}


Окончание таблицы 3

\begin{tabular}{|c|c|c|}
\hline 4. & $\begin{array}{l}\text { Опора на ролевую теорию } \\
\text { личности при организации } \\
\text { формирования поликультурной } \\
\text { компетентности студентов }\end{array}$ & $\begin{array}{l}- \text { обеспечение студентов } \\
\text { инфолноценной } \\
\text { социальных и профессиональных ролей и } \\
\text { соответствующих им функций, реализуемых в } \\
\text { поликультурном обществе; } \\
- \text { организация полноценного усвоения } \\
\text { информации, а также осуществление } \\
\text { индивидуально-ориентированных установочно- } \\
\text { мотивационных воздействий с целью } \\
\text { активизации практического освоения студентами } \\
\text { социальных / профессиональных ролей; } \\
\text { - обеспечение овладения студентами } \\
\text { эффективными стратегиями социального / } \\
\text { профессионального межкультурного общения, } \\
\text { поведения, деятельности. }\end{array}$ \\
\hline 5. & 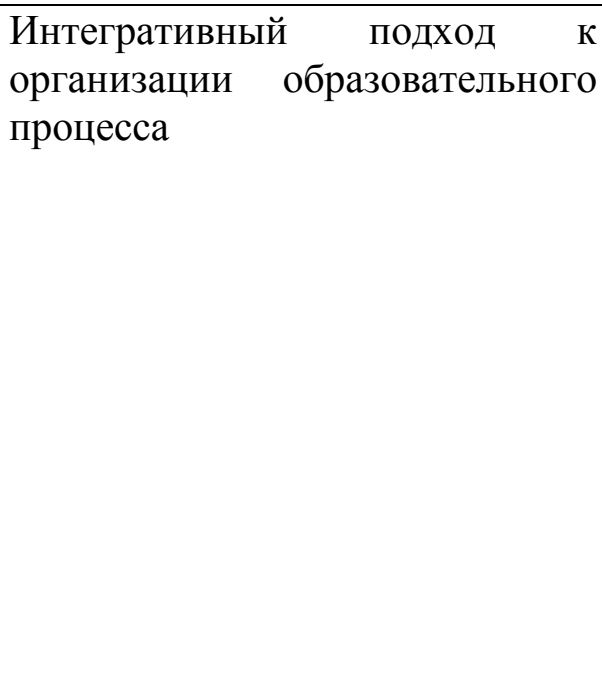 & $\begin{array}{l}\text { - разработка практических заданий на основе } \\
\text { средств и методов ситуационно-проблемного, } \\
\text { задачного, функционального и ролевого } \\
\text { подходов; } \\
\text { - разработка и применение интегративных } \\
\text { ролевых и деловых игр как формы учебно- } \\
\text { практической подготовки студентов к } \\
\text { мужкультурному взаимодействию; } \\
\text { - структурирование содержания обучения на } \\
\text { основе принциа междисциплинарной } \\
\text { интеграции с выбором интеграционного ядра, } \\
\text { соответствующего фароруемому } \\
\text { содержательному компоненту поликультурной } \\
\text { компетентности. }\end{array}$ \\
\hline
\end{tabular}

В соответствии с предметным содержанием поликультурной компетентности педагога целесообразно выделить три этапа ее формирования: социально-личностный, переходный профессиональноличностный.

На каждом этапе формируется относительно самостоятельный содержательный блок поликультурной компетентности (на первом общесоциальный, на втором - социально-профессиональный (утилитарнопрофессиональный, пассивно-профессиональный), на третьем профессиональный), структурно результаты этих этапов могут быть описаны через когнитивный, мотивационно-ценностный и деятельностноповеденческий компоненты. Это значит, что на каждом этапе должны 
решаться задачи, связанные с развитием системы знаний и умений, освоением ценностей и формированием мотивов, становлением навыков поведения и деятельности [166]. При этом целью социально-личностного этапа является освоение студентами общесоциального содержания поликультурной компетентности, становление их готовности и способности к эффективной жизнедеятельности (общению, решению общесоциальных коммуникативных задач) в условиях поликультурного общества. На переходном этапе осуществляется экстраполяция общесоциального содержания поликультурной компетентности в сферу профессиональной деятельности, становление готовности и способности студентов к эффективному педагогическому взаимодействию с учетом поликультурности профессионального сообщества. Профессионально-личностный этап нацелен на полноценное освоение студентами педагогического содержания поликультурной компетентности, становление их готовности и способности к осуществлению поликультурного воспитания учащихся.

В соответствии с указанными целями конкретизируются этапные задачи, критерии и уровни сформированности поликультурной компетентности студентов, осуществляется отбор когнитивного содержания образования, разработка ситуативно-проблемных задач, подбор средств, методов и форм организации образовательного процесса.

Исходя из закономерностей когнитивного, мотивационно-ценностного и деятельностно-поведенческого развития личности, совокупность педагогических форм, методов и приемов можно классифицировать не поэтапно, а в соответствии со структурными компонентами поликультурной компетентности, описав порядок их применения от начала к окончанию этапа. 


\section{Методы и приемы, направленные на развитие когнитивного компонента}

\section{поликультурной компетентности}

При освоении теоретического материала вначале целесообразно применение приемов мнемической деятельности, к которым относятся: прямая установка на запоминание; сознательная группировка и классификация данных; составление плана, выделение смысловых опор; сжатие, уплотнение материала; многократный возврат к материалу и др. [166].

Далее следует предлагать студентам задания, связанные с анализом и обобщением информации, после чего выводы должны быть конкретизированы в общесоциальный или профессиональный контекст межкультурного общения посредством обсуждения и разрешения соответствующих проблемных ситуаций, подбора примеров, иллюстрирующих справедливость сделанных обобщений.

\section{Методы и приемы, направленные на развитие мотивационно-ценностного}

\section{компонента поликультурной компетентности}

Для достижения полноценного мотивационного и ценностноориентирующего воздействия на учащихся, образовательные методы и приемы должны варьировать от разъяснения и убеждения до беседы, дискуссии. Особенно ценным воспитательным потенциалом обладают приемы витагенного обучения, основанные на использовании в образовательном процессе жизненного опыта учащихся, что стимулирует их оценочную деятельность и способствует принятию ценностей на уровне личностной значимости, формированию на их основе мотивов поведения [17,165]. «В контексте аксиологического воспитания наиболее эффективными являются: - прием ретроспективного анализа жизненного опыта с параллельным соотнесением его с осваиваемой ценностной информацией, определением ценностно обусловленных причин тех или иных 
поступков, событий, адекватности сложившихся отношений к данным событиям и фактам и т.д.; - дополнительное конструирование незаконченной образовательной модели (закончить фразу, предложение, описание ситуации с точки зрения тех или иных ценностных отношений, ориентаций); витагенные аналогии, при которых осуществляется иллюстрирование учащимися познаваемых ценностных категорий (явлений, событий, отношений и т.д.) примерами из их жизненного опыта» [165].

Методы и приемы, направленные на развитие деятельностно-поведенческого компонента поликультурной компетентности

Вначале необходимо научить студентов определять эффективные стратегии поведения и деятельности в разных ситуациях межкультурного взаимодействия. Для этого возможно применение тренинговых фор организации учебно-воспитательного процесса, обсуждение и разрешение ситуативно-проблемных задач. Далее следует «отработать» стратегии в игровом взаимодействии, причем характер деловых и ролевых игр может предполагать постепенное повышение «свободы» поведения участников и объемности моделируемых ситуаций. И лишь после этого поведенческие и деятельностные навыки можно реализовывать в условиях реальной межкультурной среды, причем вначале стоит обеспечить участие студентов в организованных мероприятиях (научных, культурных, общественнополитических).

Вышесказанное позволяет следующим образом представить примерную последовательность применения различных методов и приемов, (а также соответствующих им форм организации занятий), реализуемую на каждом этапе формирования поликультурной компетентности студентов.

1. Прямая установка на запоминание блока информации (лекция), группировка и классификация данных (семинар) - формируется когнитивная основа дальнейшей работы. 
2. Разъяснение аксиологического содержания информации, убеждение в социальной значимости обсуждаемых поликультурных ценностей (лекциябеседа).

3. Обсуждение индивидуально-личностного отношения к поликультурной информации, убеждение в личностной значимости поликультурных ценностей посредством применения приема ретроспективного анализа жизненного опыта, связанного с межкультурными взаимодействиями (семинар).

4. Подбор примеров поликультурного взаимодействия (конфликтных и бесконфликтных) из жизненного опыта студентов, литературы, периодики (самостоятельная работа дома).

5. Решение ситуативно-проблемных задач, связанных с анализом и оценкой ситуации, поиском и обработкой соответствующей информации, обобщение информации и формулировка выводов (семинар).

6.Выполнение заданий на поиск витагенных аналогий из жизненного опыта, иллюстрирующих сделанные выводы (семинар, самостоятельная работа дома).

7. Решение ситуативно-проблемных задач, связанных с выбором способов действий для изменения ситуации, построение стратегий эффективного поведения и деятельности в тренинговом режиме (семинар).

8. Обсуждение сконструированных индивидуальных стратегий в форме диспута, дискуссии, «профессионального боя» (семинар).

Выполнение пунктов 5,6,7,8 может быть организовано как на отдельных семинарских занятиях, так и в рамках одного семинара - в зависимости от учебного плана, расписания занятий и объема теоретической информации, подлежащей усвоению, обсуждению и осознанию.

9. Организация ролевых или деловых игр, связанных с имитацией ситуаций межкультурного взаимодействия (семинар). 
10. Решение ситуационно-проблемных задач, связанных с контролем и коррекцией поведения и деятельности, применение приема дополнительного конструирования незаконченной образовательной модели с целью проверки степени интериоризации поликультурных ценностей (семинар).

11. Перед переходом к следующему блоку информации: возврат к материалу, повторение, уплотнение материала, составление смысловых опор. После изучения большого блока теоретической информации по разным учебным дисциплинам, включенным в круг междисциплинарной интеграции, для ее усвоения организуется проектная деятельность студентов. Разработка и презентация контекстных проектов способствует внутрипредметной и межпредметной систематизации знаний, формированию ценностномотивационной основы конструктивного поведения и деятельности в поликультурной среде.

Социально-личностный этап формирования поликультурной компетентности будущих педагогов

Целью социально-личностного этапа является становление у студентов теоретической, мотивационной и практической готовности к жизнедеятельности в условиях поликультурного общества. Результат определяется как сформированность общесоциального содержательного компонента поликультурной компетентности. Соответственно, в этот период решаются следующие задачи:

1. Формирование у студентов системы знаний, связанных с поликультурными характеристиками современного социума, основаниями культурного дифференцирования общества, основами анализа и учета в межкультурном взаимодействии культурных особенностей коммуникантов.

2. Формирования ценностного отношения учащихся к культурному разнообразию общества и интереса к межкультурному взаимодействию. 
3. Формирование у студентов навыков конструктивного межкультурного взаимодействия, бесконфликтного общения, эффективных стратегий поведения в поликультурной среде.

Информационной (когнитивной) основой формирования общесоциальной поликультурной компетентности является следующая система знаний:

- исторических - история и особенности становления российской государственности, сословной системы организации общества; российская культура XIX - XX веков и ее вклад в мировую культуру; XX век глобализация общественных процессов, проблема экономического роста и модернизации, революции и реформы, социальная трансформация общества; столкновение тенденций интернационализма и национализма, интеграции и сепаратизма, демократии и авторитаризма в мировой и российской истории; внешняя и внутренняя политика, социально-экономические процессы в России ХX века и т.д;

- культурологических - основные понятия культурологии: культура, цивилизация, морфология культуры, функции культуры, субъект культуры, культурогенез, динамика культуры, язык и символы культуры, культурные коды, межкультурные коммуникации, культурные ценности и нормы, культурные традиции, культурная картина мира, социальные институты культуры, культурная самоидентичность, культурная модернизация; типология культур: этническая и национальная, элитарная и массовая культуры, восточные и западные типы культур, специфические и «серединные» культуры, локальные культуры; место и роль России в мировой культуре; тенденции культурной универсализации в мировом современном процессе; культура и природа, культура и общество, культура и глобальные проблемы современности, культура и личность, культура общества и культура человека, инкультурация и социализация;

- социологических - общество и социальные институты, мировые 
процессы глобализации; социальные группы и общности, виды общностей; общность и личность, малые группы и коллективы; понятие социального статуса; социальное взаимодействие и социальные отношения; культура как фактор социальных изменений; взаимодействие экономики, социальных отношений и культуры; личность как социальный тип, социальный контроль и девиация, личность как деятельный субъект, социальные изменения личности;

- философских - взаимосвязь человека, общества и культуры, отношения человека и природы; общество и его структура; гражданское общество и государство; человек в системе социальных связей, человек и исторический процесс: личность и массы, свобода и необходимость; смысл человеческого бытия, насилие и ненасилие, свобода и ответственность; мораль, справедливость, право, нравственные ценности; представления о совершенном человеке в различных культурах; эстетические ценности и их роль в человеческой жизни; религиозные ценности и свобода совести; будущее человечества, глобальные проблемы современности, взаимодействие цивилизаций и сценарии будущего;

- психологических - проблема человека в психологии; человек как индивид, личность, индивидуальность, субъект; биологическое и социальное в человеке; общее понятие о личности, основные факторы и механизмы развития личности, жизненный путь личности; направленность и еe психологические проявления; потребности, мотивация, деятельность; общение: функции, средства, структура, психологические характеристики; познавательная сфера; ощущения, восприятие, память, мышление, речь, воображение, внимание, эмоции; темперамент, характер и мотивация; индивидуально- психологические особенности личности.

Поликультурно-воспитательный эффект при освоении указанных знаний достигается путем межпредметной интеграции информации через 
полипредметное, контекстно-поликультурное рассмотрение теоретических вопросов, например:

- природы ценностей: понятие и характеристика ценностей в философии и психологии, роль ценностей в мотивации поведения и деятельности, разнообразие культурных ценностей и основанные на них культурные различия и т.п.;

- сущности отношений: виды отношения человека к себе и миру, природе и обществу, психологические основы формирования системы отношений, культурные особенности отношений, взаимосвязь межличностных и социальных отношений и их культурная обусловленность и т.д.;

- сущности и содержания культуры: философская интерпретация культуры, культура общества и культура личности, развитие личности и культурная идентификация, влияние базовых компонентов культуры (ценностей, отношений, норм) на развитие личности в социуме и др.;

- содержания различных культур: религиозные культуры - виды, история развития, идеи и идеалы, ценности и нормы, менталитет и направленность личности; возрастные культуры - особенности отношения к миру у представителей разных возрастных групп, их социальное положение, место и роль в общественном развитии и т.п.;

- общего и особенного в различных культурах: основания и показатели культурных различий - философские, психологические, этнические, религиозные, региональные; общечеловеческие ценности и моральные нормы как основа для консолидации и бесконфликтного общения. 
Системное рассмотрение различных аспектов поликультурности возможно как в рамках одной (или нескольких) учебных дисциплин, так и в режиме изучения специально разработанного факультативного курса.

Содержание деятельности студентов:

- Учебная деятельность:

1) Решение ситуационно-проблемных задач, примеры которых (для сферы семейных отношений) приведены в таблице 4. Задачи соотнесены с конкретной социальной ролью, выполняемый функцией, соответствующими ситуациями межкультурного взаимодействия, возможными проблемами.

Таблица 4

\section{Примеры ситуативно-проблемных задач первого этапа формирования поликультурной компетентности}

\begin{tabular}{|c|c|c|c|}
\hline Роль & Жена / муж (ч & $\begin{array}{r}\text { ген семьи, в которой } \\
\text { младшей возраст }\end{array}$ & $\begin{array}{l}\text { сть представители старшей и } \\
\text { ыых групп) }\end{array}$ \\
\hline \multirow[b]{3}{*}{ Функции } & \multicolumn{3}{|c|}{ Создателя / хранителя семейных традиций } \\
\hline & $\begin{array}{c}\text { Примеры } \\
\text { возможных } \\
\text { ситуации }\end{array}$ & $\begin{array}{c}\text { Примеры } \\
\text { возможных } \\
\text { проблем }\end{array}$ & $\begin{array}{c}\text { Примеры учебных задач, } \\
\text { направленных на разрешение } \\
\text { ситуационных проблем }\end{array}$ \\
\hline & $\begin{array}{l}\text { 1.Подготовка } \\
\text { к } \\
\text { празднованию } \\
\text { Нового года. } \\
\text { 2.Огранизация } \\
\text { свободного } \\
\text { времени в } \\
\text { выходной } \\
\text { день. }\end{array}$ & 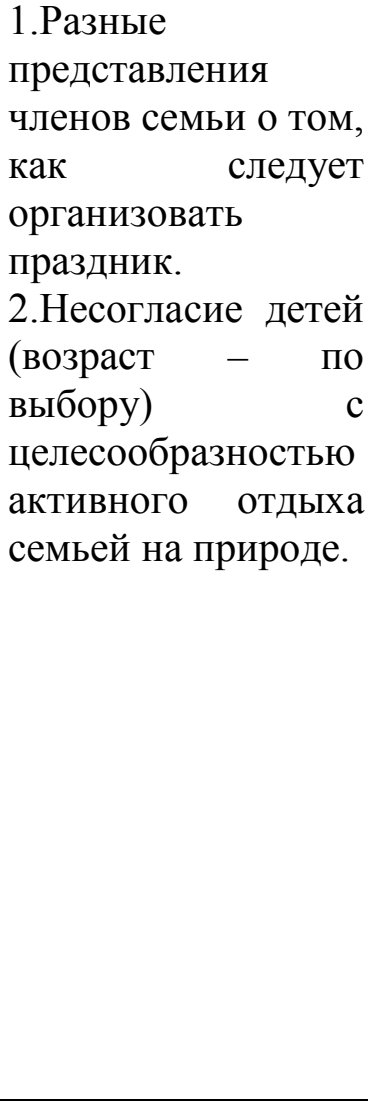 & 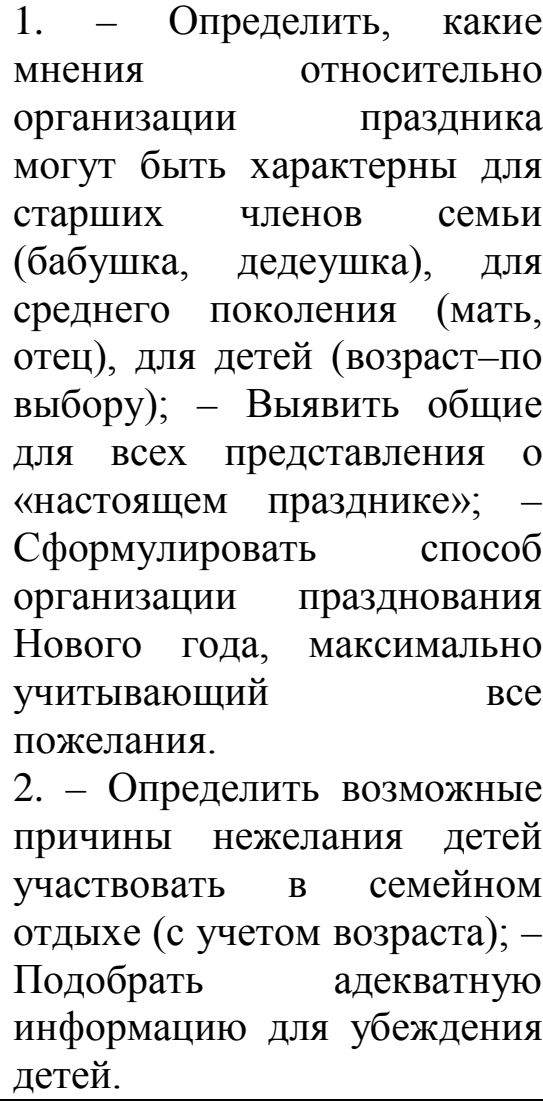 \\
\hline
\end{tabular}


Указанные задачи могут предлагаться при изучении культурологи (тема - культура семейных отношений) или социологии (тема - семья как социальная группа).

2) Участие в ролевых играх со следующей примерной тематикой:

- «В чужой монастырь»: моделируются ситуации туристической (либо деловой) поездки с и иными этнокультурными особенностями (ближнее или дальнее зарубежье); необходимо определить наиболее очевидные культурные различия, выявить нежелательные коммуникативные действия, сформулировать адекватные правила поведения и реализовать их в игровой имитации;

- «В кулуарах власти»: моделируются ситуации взаимодействия с людьми более высокого социального статуса, представителями власти; необходимо определить социально-статусные особенности коммуникантов, выработать эффективный стиль обращения к ним, разыграть ситуацию обращения за помощью;

- «Все на выборы»: моделируется ситуации агитации за конкретного кандидата в депутаты; необходимо подобрать аргументы в его пользу таким образом, чтобы убедить и мужчин, и женщин; для этого требуется определить типичные особенности женского и мужского восприятия информации и составить адекватные по содержанию обращения и т.д.

3) Подготовка и презентация проектов:

- Информативно-исследовательских, например, «Человек в поликультурном мире», «Поликультурный Я», «Природа культурных различий» и т.П.

- Творческих, например, сочинений-размышлений на тему «Мое поликультурное окружение», «Диалог культур в моей семье», «Культуры (этнические, профессиональные, гендерные, возрастные) - общее и 
особенное» и др.

- Сценарных - разработка сценариев фестивалей «Молодежные субкультуры», «Дети разных народов», «Вчера, сегодня, завтра».

4. Подготовка докладов на темы: «Межэтнические взаимодействия: история и современность», «Этнос и религия: взаимосвязь культур», «Возраст и особенности восприятия мира» и т.п.

- Самостоятельная работа: разработка проектов, подбор витагенных примеров в соответствии с решаемыми задачами, подготовка докладов.

- Внеучебная деятельность: участие в факультетских, университетских культурных мероприятиях: в фестивале «Студенческая весна», конкурсах команд «КВН», в гражданских акциях.

\section{Переходный этап}

На переходном этапе формируется социально-профессиональный блок поликультурной компетентности в виде готовности и способности студентов к эффективному педагогическому взаимодействию с учетом поликультурности профессионального сообщества. Задачами данного этапа являются:

1) Развитие системы знаний, связанных с поликультурными характеристиками профессионального окружения, профессиональными ситуациями межкультурного взаимодействия, целями и способами учета культурных различий в профессиональной деятельности.

2) Развитие ценностного отношения студентов к индивидуальным культурным особенностям субъектов педагогической деятельности и стремления учитывать эти особенности в своей работе; 
3) Становление навыков организации межкультурного взаимодействия учащихся, эффективного поведения в поликультурной профессиональной среде.

Базовыми для решения указанных задач знаниями являются следующие знания:

- из области русского языка и культуры речи - речевое взаимодействие и основные единицы общения; литературный язык, нормативные, коммуникативные, этические аспекты устной и письменной речи; функциональные стили современного русского языка как языка межнационального общения; официально-деловой стиль, сфера его функционирования, жанровое разнообразие, интернациональные свойства русской официально-деловой письменной речи; речевой этикет в документе; жанровая дифференциация и отбор языковых средств в публицистическом стиле; особенности устной публичной речи; подготовка речи: выбор темы, цель речи, поиск материала, начало, развертывание и завершение речи, словесное оформление публичного выступления; понятность, информативность и выразительность публичной речи; разговорная речь в системе функциональных разновидностей русского литературного языка; условия функционирования разговорной речи, роль внеязыковых факторов; основные направления совершенствования навыков грамотного письма и говорения;

- психологические - психологические особенности и парадигмы образовательного процесса; педагогическая деятельность: психологические особенности, структура, механизмы, учитель как субъект педагогической деятельности; проблема возраста и возрастная периодизация; психическое развитие: условия, источники, предпосылки, факторы, характеристики, механизмы; дошкольный возраст: кризисы и ведущие деятельности, особенности мотивов поведения, эмоциональной сферы, самосознания, мышления; младший школьный возраст: кризис семи лет, учебная 
деятельность как ведущая и как источник психического развития личности; подростковый возраст: чувство взрослости, проблемы общения, самосознание, потребность в самоутверждении, трудный подросток; период юности: ранняя юность, формирование мировоззрения, профессиональное самоопределение; этапы взрослости: кризисы на этапе взрослости, возраст и проблемы смысла жизни; пожилой возраст: старость как социальная и психологическая проблема;

- педагогические - образование как общественное явление и педагогический процесс целенаправленного воспитания и обучения в интересах человека, общества и государства; взаимосвязь педагогической науки и практики; культура педагога, научное исследование в педагогике; субъекты педагогической деятельности и педагогического общения; понятие педагогических технологий, их обусловленность характером педагогических задач; виды педагогических задач, проектирование и процесс их решения; права ребенка и формы его правовой защиты в законодательстве Российской Федерации; раздел «педагогика начального образования» - социализация личности ребенка в системе начального образования, показатели сформированности социальной активности ребенка; содержание, виды, формы социально-педагогической работы с младшими школьниками; социальная направленность познавательной, нравственной, коммуникативной, художественно-эстетической, трудовой, физкультурноспортивной деятельности детей младшего школьного возраста.

Уровень межпредметной интеграции повышается: полипредметное рассмотрение теоретических вопросов включает не только аспекты, рассмотренные на данном этапе, но и базовую информацию предыдущего этапа:

- особенности общения в поликультурной среде: способы и основания культурной идентификации участников общения, возрастные и гендерные 
особенности восприятия информации, причины конфликтов в общении, связанные с культурными различиями и способы их преодоления, выбор речевых средств коммуникации в поликультурной среде и др.;

- культурные ценности как основа обогащения личного опыта: этнокультурный опыт разрешения конфликтов, исторические примеры межкультурного взаимодействия, социум как единство и разнообразие культур, профессиональный опыт и способы его накопления и т.п.;

- молодежные субкультуры: философский взгляд на природу молодежных субкультур, место субкультур в социуме, возрастные характеристики субкультур, психологические особенности восприятия и поведения в молодежных субкультурах и т.д.;

- поликультурность профессионального окружения: субъекты профессионально-педагогического взаимодействия, дифференцирование профессионального окружения по основанию культурных особенностей, коллеги, учащиеся, родители учащихся как представители разных профессиональных, этнических, гендерных, возрастных, статусных культур и др.

Содержание деятельности студентов:

- Учебная деятельность:

1) Решение ситуационно-проблемных задач, связанных с освоением умений выявлять и учитывать межкультурные различия людей в профессиональном взаимодействии (таблица 5). 
Таблица 5

\section{Примеры ситуативно-проблемных задач второго этапа} формирования поликультурной компетентности

\begin{tabular}{|c|c|c|c|}
\hline Роль & \multicolumn{3}{|c|}{$\begin{array}{c}\text { Педагог (член профессионального коллектива, в котором есть } \\
\text { представители старшей и младшей возрастных групп, разных этнических } \\
\text { и социально-статусных групп) }\end{array}$} \\
\hline \multirow[t]{3}{*}{ Функции } & \multicolumn{3}{|c|}{ Участника / организатора межкультурного профессионального общения } \\
\hline & $\begin{array}{c}\text { Примеры } \\
\text { возможных } \\
\text { ситуации } \\
\end{array}$ & $\begin{array}{c}\text { Примеры } \\
\text { возможных } \\
\text { проблем } \\
\end{array}$ & $\begin{array}{c}\text { Примеры учебных задач, } \\
\text { направленных на разрешение } \\
\text { ситуационных проблем }\end{array}$ \\
\hline & $\begin{array}{l}\text { 1.Освоение } \\
\text { педагогического } \\
\text { опыта коллег. } \\
\text { 2.Подготовка к } \\
\text { родительскому } \\
\text { собранию. } \\
\text { 3.Подготовка } \\
\text { классного часа с } \\
\text { обсуждением } \\
\text { темы дружбы } \\
\text { между однолассниками. } \\
\text { однокла }\end{array}$ & 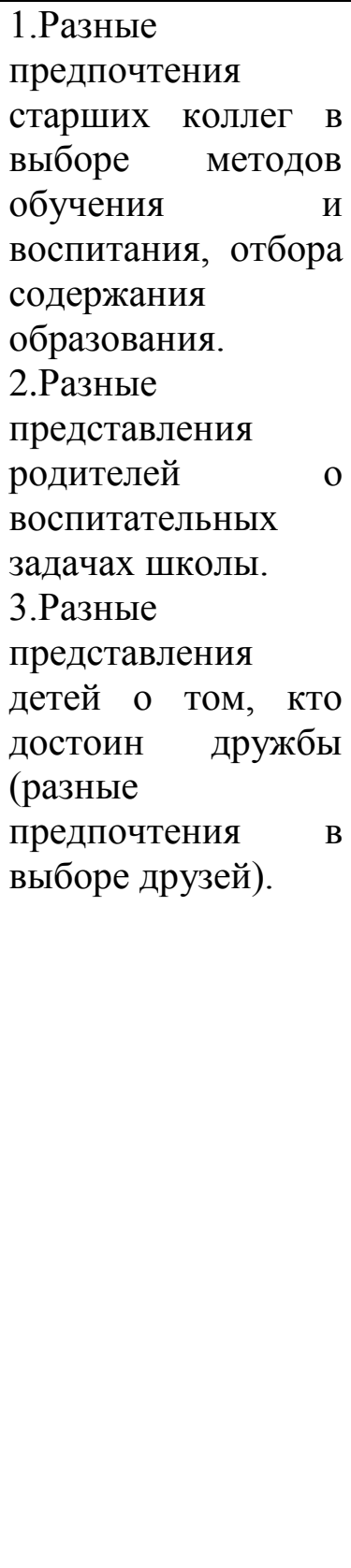 & 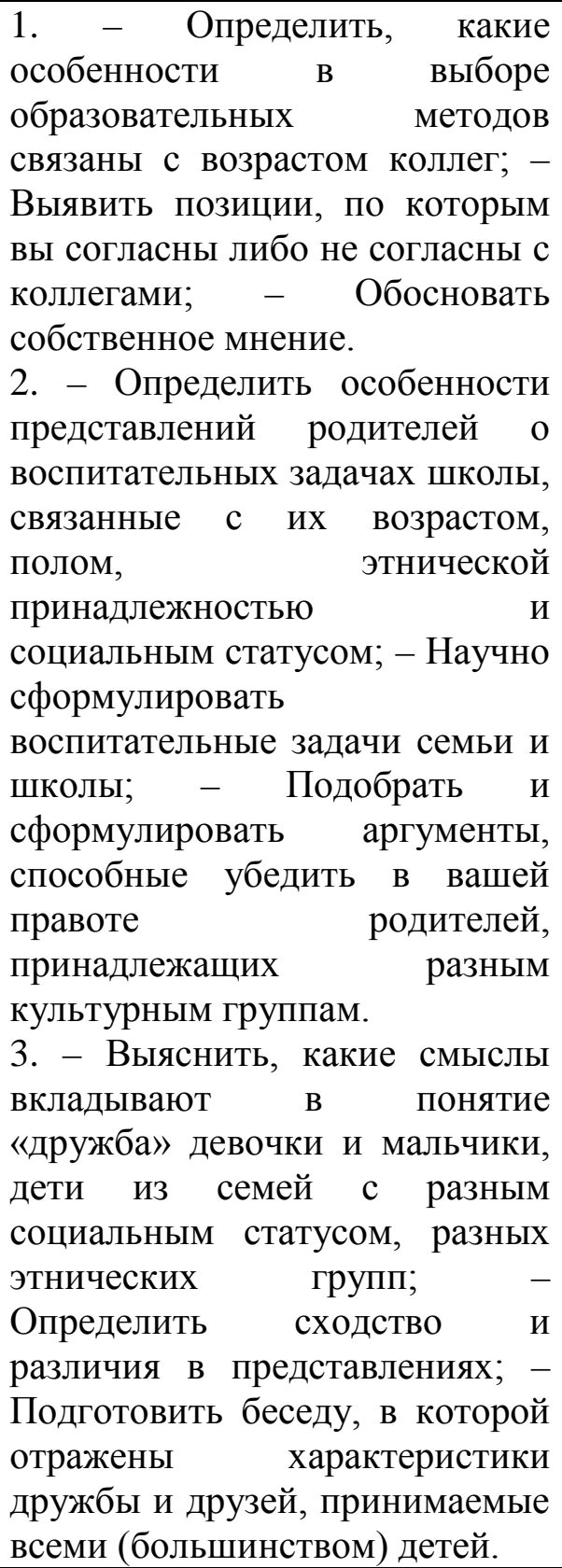 \\
\hline
\end{tabular}


Указанные задачи целесообразно решать при изучении педагогики и психологии.

2) Участие в ролевых играх следующей тематики:

- «Я - родитель», в которой моделируется ситуация родительского собрания в школе, а участники выступают в роли родителей; при этом для каждого участника задается этническая принадлежность (не обязательно соответствующая действительной), отношение к религии (конфессионная принадлежность, религиозность/атеизм), социальный статус (должность, профессия, место работы); в ходе игры определяются: - варианты конструктивного поведения родителей; - типичные для представителей разных социокультурных групп поведенческие стереотипы; - способы изменения поведения представителей разных культурных групп.

- «Совместный отдых», построенный на имитации организованного выходного дня учителя, учащихся, их родителей; предполагается неформальное общение с родителями с учетом их социокультурной принадлежности и т.п.

3) Участие в деловых играх, таких, как:

- «Родительское собрание», имитирующее классное или общешкольное родительское собрание, связанное с решением учебных, воспитательных или организационных вопросов; участники поочередно выступают в роли педагогов (администрации), в из задачи входит подготовка информационного сообщения о положении дел (учебновоспитательных, финансово-материальных и т.д.), существующих проблемах таким образом, чтобы родители, принадлежащие разным социокультурным группам, адекватно восприняли информацию, серьезно к ней отнеслись и приняли участие (не формальное) в обсуждении вопросов.

- «Педагогический совет» - имитация собрания преподавательского 
коллектива, представленного разными возрастными и гендерными, этническими и социально-статусными группами; участникам необходимо определить стиль общения в ситуациях «старший коллега - молодой специалист», «рядовой преподаватель - представитель школьного руководства», «мужчина - женщина».

4) Разработка и презентация проектов, например: «Социокультурный анализ ученического коллектива» (конструктивно-практический проект, предполагающий разработку дневника наблюдений за учащимися); «Золотые правила работы с родителями» (информативноисследовательский проект, направленный на выяснение задач, определения способов конструктивного взаимодействия с родителями учащихся); «Учитель-ученик: особенности взаимного восприятия» (творческий проект, предполагающий поиск способов повышения адекватности оценки друг друга участниками педагогического взаимодействия) и т.п.

5) Участие в «профессиональных боях» и дискуссиях на тему: «Что важнее: профессиональный опыт или «свежие» знания», «Работа с учащимися: обсуждение различий или поиск сходства», «Взаимодействие с родителями учащихся: какой стиль общения выбрать» и т.д.

- Самостоятельная работа студентов: подготовка докладов, разработка проектов, подготовка к участию в дискуссиях, «профессиональных боях», ролевых и деловых играх.

- Внеучебная деятельность студентов:

1) Участие в научно-практических конференциях (студенческих, студенческо-преподавательских, разного уровня - факультетских, университетских, городских и т.д.), тематика которых связана с обсуждением вопросов обмена педагогическим опытом, современного состояния учебно-воспитательной практики в школе, проблем гендерной, 
социальной, возрастной психологии и т.д.

2) Педагогическая практика, в процессе которой выполняются следующие задания: социокультурный анализ учащихся (класса), социокультурный анализ родителей учащихся (класса), социокультурный анализ педагогического коллектива.

\section{Профессионально-личностный этап}

Цель этапа - формирование специально-профессионального блока поликультурной компетентности - достигается через последовательное решение задач:

1) Становление системы знаний, связанных с основами организации поликультурного воспитания учащихся;

2) Формирование ценностного отношения к поликультурному воспитанию как содержанию педагогической деятельности, педагогической миссии;

3) Развитие у студентов конструктивных и методических умений и навыков, связанных с поликультурным воспитанием учащихся.

На этом этапе освоению подлежит следующая информация, включающая систему специальных, предметных знаний будущих педагогов (представлены на примере учебного плана подготовки будущих педагогов начального образования):

- по психологии - учение как деятельность, психологическое содержание и структура учебной деятельности, формирование психологической системы учебной деятельности и ее компонентов; ученик как субъект учебной деятельности, школьная отметка и оценка, психологические причины школьной неуспеваемости, психологическая готовность к обучению; психологическая сущность воспитания, его критерии; воспитание как путь к сознанию и смыслу, воспитание как 
процесс, направленный на усвоение нравственных норм; мораль, нравственность, духовность, развитие и воспитание духовности;

- по общей педагогике - понятие педагогических технологий, их обусловленность характером педагогических задач; виды педагогических задач (учебных и воспитательных), проектирование и процесс решения педагогических задач; общая характеристика и виды педагогических технологий (обучения, воспитания, развития);

- по «Педагогике начального образования» как специальной дисциплине - личность младшего школьника как объект и субъект педагогических воздействий, профессиональные знания и умения учителя начальной школы; противоречия процесса познания и их разрешение в учебной деятельности младших школьников; зависимость обучения детей от закономерностей познания человеком окружающего мира; современные концепции и технологии педагогического процесса в начальной школе, функции педагогического процесса в начальных классах: образовательная (содержание, структурные компоненты, виды образовательных задач и методы их реализации в учебном процессе), воспитательная (содержание, структурные компоненты, виды воспитательных задач и методы их реализации в учебном процессе), развивающая (содержание структурные компоненты, виды развивающих задач и методы их реализации в учебном процессе начальной школы); сущность и функции чувственного образа и управление чувственным познанием детей в учебном процессе; абстракции и формирование логических суждений, операций и приемов у детей; методы обучения и формы организации обучения в начальных классах; диагностика развития личности ребенка в образовательном процессе; воспитание в структуре педагогического процесса начальной школы, регулятивная направленность методов воспитания; свободная активность ребенка и проблемы ее ограничения; воспитательная работа с коллективом детей, 
общество сверстников как фактор воспитания качеств личности ребенка; вариативные системы и методы организации воспитательного процесса в начальных классах; нравственное и эстетическое воспитание; формирование здорового образа жизни; диагностика воспитательной деятельности в начальной школе; методы и формы организации работы с родителями младших школьников;

— по «Детской литературе» как специальной дисциплине: специфика детской литературы: художественный и педагогический компоненты, круг детского чтения, жанры детского фольклора и их воспитательное содержание; система жанров детской литературы, тенденции развития современной детской литературы; научные основы анализа произведений детской литературы при работе с младшими школьниками.

Примеры интегративного рассмотрения контекстных теоретических вопросов:

- поликультурное воспитание младших школьников: характеристика поликультурного воспитания учащихся, формы и методы поликультурного воспитания, психологические основы поликультурного развития младших школьников, социальные реалии и поликультурное воспитание учащихся; исторические факты как содержание поликультурного воспитания младших школьников, примеры поликультурной личности в произведениях детской литературы и т.п.;

- диагностика поликультурных особенностей коллектива учащихся: философские и психологические основы выделения культурных различий, методы оценки уровня толерантности в ученическом коллективе, способы определения ценностных ориентаций школьников и т.д.;

- взаимодействие с родителями учащихся: задачи и содержание работы с родителями учащихся, способы культурной идентификации и дифференциации членов родительского коллектива, выбор поведенческих стратегий в зависимости от культурной принадлежности родителей и пр.; 
- поликультурное воспитание школьников во внеучебной работе: виды и формы внеучебной работы с учащимися, культурно-психологические основы вовлечения учащихся и их родителей в совместное творчество, совместный досуг и др.

Содержание деятельности студентов:

- Учебная деятельность:

1) Решение ситуационно-проблемных задач, содержание которых связано с вопросами поликультурного воспитания учащихся (таблица 6).

Таблица 6

Примеры ситуативно-проблемных задач третьего этапа формирования поликультурной компетентности

\begin{tabular}{|c|c|c|c|}
\hline Роль & \multicolumn{3}{|c|}{ Педагог (в ученическом коллективе) } \\
\hline \multirow[t]{3}{*}{ Функции } & \multicolumn{3}{|c|}{ Организатора поликультурного воспитания учащихся } \\
\hline & $\begin{array}{c}\text { Примеры } \\
\text { возможных } \\
\text { ситуации }\end{array}$ & $\begin{array}{c}\text { Примеры } \\
\text { возможных } \\
\text { проблем }\end{array}$ & $\begin{array}{c}\text { Примеры учебных задач, } \\
\text { направленных на разрешение } \\
\text { ситуационных проблем }\end{array}$ \\
\hline & $\begin{array}{l}\text { 1. Организация } \\
\text { дружеских } \\
\text { отношений между } \\
\text { учащимися. } \\
\text { 2.Подготовка } \\
\text { беседе } \\
\text { культурном } \\
\text { многообразии } \\
\text { российского } \\
\text { общества на основе } \\
\text { литературных } \\
\text { примеров. } \\
\text { З.Подготовка } \\
\text { классного часа с } \\
\text { обсуждением } \\
\text { понятия равенства } \\
\text { между людьми. }\end{array}$ & $\begin{array}{l}\text { 1.Конфронтация } \\
\text { между мужской и } \\
\text { женской } \\
\text { половинами } \\
\text { ученического } \\
\text { коллектива } \\
\text { (между } \\
\text { мальчиками и } \\
\text { девочками). } \\
\text { 2.Разный } \\
\text { литературный } \\
\text { кругозор детей, } \\
\text { литературные } \\
\text { вкусы, связанные } \\
\text { с этнической } \\
\text { принадлежностью. } \\
\text { 3.Наличие } \\
\text { классе } \\
\text { представителей } \\
\text { семей с разными } \\
\text { финансовыми } \\
\text { возможностями и } \\
\text { социальным } \\
\text { статусом. }\end{array}$ & $\begin{array}{l}\text { 1. - Определить возможные причины } \\
\text { ссоры, обусловленные возрастными } \\
\text { особенностями девочек и мальчиков; - } \\
\text { Подготовить понятные детям объяснения } \\
\text { о различиях в поведении и общени, } \\
\text { свойственным мальчикам и девочкам; - } \\
\text { Подготовить беседу о роли мужчин и } \\
\text { женщин в мире и правильных } \\
\text { отношениях друг кдругу. } \\
\text { 2. - Выяснить, какие произведения из } \\
\text { национальной литературы читали дети; - } \\
\text { Подобрать Контекстные примеры из } \\
\text { мифологии, устного народного } \\
\text { творчества, художественных } \\
\text { произведений народов, представленных в } \\
\text { ученическом коллективе. } \\
\text { 3. - Выяснить, что понимают дети под } \\
\text { «равенством между людьми», в чем, по } \\
\text { их мнению, проявляется равенство; - } \\
\text { Проанализировать (на основе беседы с } \\
\text { родителями, их анкетирования) } \\
\text { социально-статусный состав их семей и } \\
\text { социальное происхождение; - Подобрать } \\
\text { аргументы, примеры, соответствующие } \\
\text { семейному окружению учащихя для } \\
\text { формирования у детей адекватного } \\
\text { представления о понятии «равенство». }\end{array}$ \\
\hline
\end{tabular}


Указанные задачи могут решаться при изучении детской литературы, психологии, педагогики начального образования.

2) Участие в деловых играх, таких, как:

- «Планирование воспитательной работы», в которой моделируется ситуация выбора и обсуждения на педагогическом совете тематики классных часов и культурно-познавательных мероприятий (конкурсов, олимпиад, экскурсий и т.п.), направленных на решение задач поликультурного воспитания учащихся; участникам необходимо обосновать свой план воспитательной работы, определить необходимый информационный и иллюстративный материал, указать конкретные решаемые задачи, отразить возможные межкультурные (гендерные, возрастные, этнические, статусные) различия детей, влияющие на восприятие ими информации.

- «Классный час», имитирующей проведение учителем классного часа поликультурного содержания; студенты поочередно выступают в роли учителя и учащихся, определяют, в какие моменты возможно возникновение проблемных ситуаций, связанных с межкультурными различиями учащихся, определяют способы разрешения гипотетических проблем и др.

3) Разработка проектов:

- сценарного типа: - «Экскурсия» (организация экскурсии, похода выходного дня, содержание которых предполагают возможность осуществления поликультурно-воспитательных воздействий на учащихся), - «Праздники и народные традиции» (сценарий конкурса или фестиваля народной культуры, фольклора, организации этнических или религиозных праздников),

- информативно-исследовательского или конструктивно- 
практического типа: - «Воспитание родителей» (разработка плана работы с родителями по вопросам поликультурного воспитания учащихся, включая социокультурный анализ семей, определение культурных особенностей семей, проблем, связанных с межкультурным взаимодействием и способов их разрешения), - «Культурный портрет ученического коллектива» (исследование реального коллектива учащихся с точки зрения культурных особенностей, различий и т.п., осуществляется во время педагогической практики) и др.

4) Прохождение педагогической практики с выполнением заданий по поликультурному воспитанию учащихся.

- Самостоятельная работа студентов: теоретическая и методическая подготовка к решению задач поликультурного воспитания учащихся в период педагогической практики, подготовка проектов, подготовка к участию в деловых играх.

- Внеучебная деятельность: подготовка и участие в студенческих научно-методических конференций по вопросам поликультурного воспитания младших школьников. 


\section{6. ДИАГНОСТИКА И ОЦЕНКА УРОВНЯ СФОРМИРОВАННОСТИ ПОЛИКУЛЬТУРНОЙ КОМПЕТЕНТНОСТИ БУДУЩИХ ПЕДАГОГОВ}

Для поэтапной диагностики уровня сформированности поликультурной компетентности целесообразно применение следующих методов:

1) Оценивание когнитивного компонента поликультурной компетентности осуществляется следующим образом:

- по результатам итогового контроля знаний студентов по учебным дисциплинам соответствующего этапа;

- интегрированной оценки уровня знаний по специально разработанным тестам, содержание вопросов соответствовало осваиваемым на конкретных этапах учебным дисциплинам;

- вывод о степени когнитивного поликультурного развития студентов делался с учетом обеих оценок.

2) Мотивационно-ценностный компонент поликультурной компетентности оценивается с помощью:

- тестирований, предполагающих а) ранжирование поликультурных ценностей, осваиваемых на конкретном этапе, б) оценку личностной значимости поликультурных ценностей, осваиваемых на конкретном этапе;

- анкетирования, направленного на выяснение отношения стимулов (мотивов), которые детерминируют или могут детерминировать активность студентов в межкультурном взаимодействии, содержательно соответствующем задачам конкретного этапа;

- анкетирования, направленного на выявление наличия, силы и направленности интересов студентов относительно межкультурного взаимодействия. 
3) Для оценки деятельности и поведения студентов в условиях межкультурного взаимодействия возможно использование следующих методов:

- педагогическое наблюдение и экспертная оценка активности студентов в организованных мероприятиях, связанных с межкультурным взаимодействием, и нерегламентированной активности аналогичного содержания за весь оцениваемый период;

- педагогическое наблюдение за поведением студентов в ситуациях межкультурного взаимодействия;

- экспертная оценка результатов деятельности студентов в ситуациях (плановых мероприятиях учебного, учебно-практического и практического характера) межкультурного взаимодействия, соответствующих задачам конкретного этапа.

Совокупность вопросов для оценки системности знаний студентов, стимульный материал анкетирования и тестирования, a также конкретизация параметров педагогического наблюдения и экспертной оценки дифференцируется в зависимости от вида контроля: констатирующий, промежуточный (этапный), итоговый.

\section{Первичная диагностика}

Первичная диагностика при констатирующем исследовании уровня поликультурной компетентности студентов осуществляется с применением следующего стимульного материала:

1) Перечень вопросов и заданий для интегративной оценки знаний студентов в области культуры, культурных различий, поликультурности:

- Что такое «культура», «культура общества», «культура личности»? 
- Какие виды культур Вы знаете?

- Что такое «культурные различия», в чем они проявляются?

- Что представляет собой человек как субъект и носитель культуры?

- Приведите примеры межкультурного взаимодействия.

- Можно ли назвать любого человека поликультурным? Почему?

- Охарактеризуйте себя с точки зрения поликультурности.

- Какие социальные ценности можно считать культурными? К каким видам культуры они относятся?

- Какие ценности и ценностные ориентации личности можно отнести к поликультурным? Почему?

- Что такое «толерантность»? В чем она проявляется?

2) Стимульный материал для анкетирования и тестирования:

a) Оцените по 6-балльной шкале (от 0 до 5) степень значимости для культурного развития личности, общества, цивилизации следующих ценностей: - толерантность, - равенство возможностей для всех людей, культурное многообразие, - плюрализм культурных идей и идеалов, возможность свободно общаться представителям разных культур, бережное отношение к культурному наследию своего народа, - бережное отношение к культурному наследию других народов, - просвещение в области различных культур, - конституционное обеспечение равных возможностей людям разных национальностей и рас, - правовая защита прав детей и стариков, - равенство возможностей для мужчин и женщин, уважительное отношение к представителям разных профессий.

Суммарная оценка варьирует от о до 60 баллов, при этом сумма баллов от 0 до 20 характеризует практически несогласие с социальной значимостью поликультурных ценностей, от 21 до 40 баллов - не полное 
признание социальной важности поликультурных ценностей, от 41 до 60 баллов - полноценное осознание социальной значимости поликультурных ценностей.

б) Проранжируйте ценности из предложенного списка по степени их значимости для вас как члена поликультурного общества (номера ценностей, которые можно отнести к поликультурным, выделены жирным шрифтом):

Таблица 7

Ранжирование ценностей поликультурного взаимодействия по степени их личностной значимости

\begin{tabular}{|c|c|c|}
\hline № & Список ценностей & Ранг (номер) \\
\hline 1 & Здоровье & \\
\hline 2 & Общественное признание & \\
\hline 3 & Материальное благополучие & \\
\hline 4 & Интерес к содержанию национальных культур & \\
\hline 5 & Профессиональная карьера & \\
\hline 6 & Высокий социальный статус & \\
\hline 7 & $\begin{array}{l}\text { Оценка человека не зависимо от его культурной } \\
\text { принадлежности }\end{array}$ & \\
\hline 8 & Активное общение между людьми & \\
\hline 9 & Любовь, хорошая, дружная семья & \\
\hline 10 & Интерес к людям - представителям иных культур & \\
\hline 11 & Власть & \\
\hline 12 & Интересная работа & \\
\hline 13 & $\begin{array}{l}\text { Полное использование своих возможностей, сил и } \\
\text { способностей }\end{array}$ & \\
\hline 14 & Доброжелательное отношение окружающих & \\
\hline 15 & Плюрализм мнений & \\
\hline 16 & Наличие большого количества друзей & \\
\hline 17 & Непримиримость к недостаткам в себе и других & \\
\hline 18 & Толерантность & \\
\hline 19 & Большие заработки & \\
\hline 20 & $\begin{array}{l}\text { Понимание } \\
\text { окружающим }\end{array}$ & \\
\hline
\end{tabular}


Если из шести поликультурных ценностей, отраженных в списке, в первую десятку иерархии попали 1-2, это характеризует неприятие поликультурных ценностей как личностно значимых, если 3-4 недостаточное принятие, 5-6 - полное осознание поликультурных ценностей как личностно значимых.

в) Обозначьте свое согласие (да) или несогласие (нет) с каждым из нижеприведенных утверждений:

1. Человек может быть хорошим и плохим не зависимо от его национальной принадлежности.

2. Я предпочитаю общаться с представителями своей национальности.

3. Любая религия учит, прежде всего, добру и нравственности.

4. На стариков не стоит раздражаться - они прожили долгую жизнь и могут многому научить.

5. Существуют нации, представители которых умнее (талантливее, предприимчивее и т.п.), чем представители других народов.

6. Для дружбы не важно, какое социальное положение у человека, я стараюсь общаться с разными людьми.

7. Дети должны слушаться взрослых; непослушание - это или капризы, или невоспитанность.

8. Среди моих друзей есть представители самых разных национальностей, а также люди, приехавшие из других регионов.

9. Мне интересна история других народов, их культурные традиции и обычаи и я стараюсь их узнать получше

10. Знать традиции, свойственные иным религиям, совсем не обязательно.

11. Ребенок достоин уважительного отношения. 
12. При общении с мужчинами / женщинами я учитываю, что они по разному могут относиться к некоторым явлениям, событиям, фактам и иметь разные интересы.

13. Друзей следует выбирать из людей своего круга, я стараюсь не общаться с людьми иного социального статуса.

14.В людях мне интересно все, что отличает их от меня.

15. Информация, события - это только информация и события, они не могут восприниматься по разному.

16. Взрослые не ориентируются в современной жизни, поэтому не стоит к ним особо прислушиваться.

17. Нормально общаться можно только с людьми, похожими на вас.

18. Главное - ориентироваться в своей национальной культуре и истории своего народа, знания о других народов не нужны, я не трачу на свое время.

Согласие с утверждениями №№ 1,3,4,6,8,9,11,12,14 и несогласие с утверждениями №№ 2,5,7,10,13,15,16,17,18 свидетельствуют о ценностном, толерантном отношении к культурным отличиям людей, о наличии интереса к иным культурам и стремления к межкультурному взаимодействию. При этом количество совпадений от 1 до 6 соответствует низкому интересу и стремлению, от 7 до 12 - среднему, от 13 до 18 - сильному.

3) Параметры педагогического наблюдения и экспертной оценки.

В процессе констатирующего исследования деятельностноповеденческий компонент оценивался педагогами по результатам наблюдения за неформальным общением студентов по таким показателям:

- активность и конструктивность (позитивность) взаимодействия с представителями иных национальностей, 
- уважительное отношение к чужому мнению, отличие которого от собственного связано с гендерными, национальными, религиозными, субкультурными, социально-статусными особенностями,

- способность договориться, не взирая на разные мнения и вкусы.

Высокому уровню поликультурной компетентности соответствует сформированная система поликультурных знаний, понимание значения культурного многообразия для общества и личности, наличие представлений о связанных с этим многообразием возможностей для обогащения собственного культурного опыта и необходимых в данном контексте коммуникативных и поведенческих умениях.

Средний уровень поликультурной компетентности проявляется в виде относительно верного понимания сущности культуры и поликультурности, культурных различий, ограниченных уже не только этнической принадлежностью, но включающими, в отдельных случаях, характеристики, связанные с возрастными особенностями (молодежные субкультуры). С точки зрения развития общества, мирного сосуществования культурное многообразие оценивается позитивно, однако, как это многообразие должно влиять на поведение и деятельность личности, не осознается.

Низкий уровень поликультурной компетентности характеризуется незнанием базовых элементов культуры, не пониманием их взаимосвязи с межкультурными различиями, значения этих различий в коммуникативных связях между представителями разных культурных групп. Студенты с нихким уровнем поликультурной компетентности, если и признают социальную и личностную значимость интернационализма и равенства представителей разных этносов, все-равно не связывают культурные различия с особенностями поведения, не проявляют склонности к учету этих особенностей в собственном поведении и деятельности. 


\section{Оценка результатов первого этапа формирования поликультурной}

\section{компетентности студентов}

Для оценки результатов первого этапа используется следующий диагностический материал:

1) Список вопросов и заданий для определения системности поликультурных знаний студентов:

- Дайте определение понятию «культура», включая философские, социологические, психологические аспекты.

- Сравните исторические периоды развития России и развитие отечественной и мировой культуры. Какая связь между развитием государства и общественной культуры?

- Назовите базовые элементы культуры личности. как они связаны с культурой общества?

- Какие виды культуры Вы знаете? Какие виды национальных и религиозных культур представлены в регионе Вашего проживания? Взаимосвязано ли развитие различных этнокультур в историческом аспекте?

- По каким характеристикам людей можно дифференцировать по разным культурным группам?

- Какие социальные группы Вы знаете? Носителями каких культурных особенностей являются представители одной из социальных групп (по выбору)?

- Какие культурные особенности характерны для представителей мужской / женской культур?

- Какие возрастные периоды развития человека вы знаете? Какие культурные особенности характерны для представителей возрастной 
группы (по выбору)?

- Что такое «социальный статус», «социальное положение»? По каким культурным основаниям различаются представители разных социальностатусных групп?

- Охарактеризуйте свою семью / круг своих друзей с точки зрения представленных в ней / в нем культур.

Уровень теоретической подготовки студентов определялся на основе итоговых оценок по истории и психологии (с конкретизацией оценок по блокам поликультурных знаний) и по результатам опроса.

2) Стимульный материал для анкетирования и тестирования:

а) Определение осознанности студентами социальной значимости поликультурных ценностей и степени личностной значимости этих ценностей для учащихся осуществлялось по тому же стимульному материалу, что и в констатирующем исследовании, что обусловлено задачами первого этапа формирования поликультурной компетентности, а также когнитивным содержанием образования в этот период.

б) Определение интереса к иным культурам и мотивационной направленности студентов на межкультурное взаимодействие осуществлялось путем их согласия / несогласия с нижеследующими утверждениями:

1. Ни в коем случае нельзя создавать семью с представителями иных национальностей (конфессий).

2. Я не понимаю, чем может обогатить меня общение с маленькими детьми.

3. Чтобы нормально общаться с людьми старшего поколения, я стараюсь понять, чем, кроме возраста, они от меня отличаются. 
4. Я интересуюсь только культурой своего народа.

5. Каждый человек - это «калейдоскоп культур», с любым может быть интересно общаться.

6. Меня бы возмутило строгое деление общества по национальному, религиозному или расовому признаку.

7. Находить друзей, формировать круг общения, работать лучше среди представителей своей нации, расы, конфессии.

8. Люди интересны друг другу благодаря своей несхожести.

9. Мне хочется участвовать в праздниках, относящихся к иным культурным традициям.

10. Я стараюсь получше узнать культуру народов, живущих рядом со мной.

11. При выборе спутника (спутницы) жизни я не стану преимущественно ориентироваться на его национальность (религию).

12. Дети - особый мир, у которого многому могут поучиться взрослые.

13. Я даже не пытаюсь договориться с теми, кто на много старше меня.

14.Я готов отстаивать права представителей иной культуры.

15. Важно поддерживать собственные культурные традиции, а не участвовать в чужих обрядах.

16. Сейчас почти все похожи друг на друга, отдельные представители человечества не представляют интереса.

17. Ничего интересного в различиях между людьми нет, они только мешают нормально общаться.

18. Следует бороться за справедливость только в том случае, если это касается собственной культурной общности. 
Согласие с утверждениями №№ 3,5,6,8,9,10,11,12,14 и несогласие с утверждениями №o $1,2,4,7,13,15,16,17,18$ свидетельствуют о наличии интереса к иным культурам и стремления к межкультурному взаимодействию. При этом количество совпадений от 1 до 6 соответствует низкому интересу и стремлению, от 7 до 12 - среднему, от 13 до 18 сильному.

3) Параметры педагогического наблюдения и экспертной оценки:

- степень участия студентов в организованных мероприятиях по межкультурному взаимодействию (отношение количества мероприятий, в котором студент принимал участие, к общему количеству мероприятий),

- количество мероприятий, в которых студент выступил инициатором и организатором,

- доброжелательность, толерантность, активность, инициативность в межкультурном неформальном общении,

- характер деятельности / поведения студентов (пассивное, активное, нормативно-заданное) при участии в организованных мероприятиях,

- качество результатов поведения / деятельности студентов в ситуациях межкультурного взаимодействия (способность предупреждать или конструктивно разрешать возникающие конфликты, достичь взаимопонимания, решить поставленные задачи (коммуникативные, учебные, воспитательные)).

Низкий уровень свидетельствует о том, что учащиеся практически не освоили теоретический материал, либо не способны анализировать усвоенные знания в контексте межкультурного взаимодействия в поликультурном обществе. У них практически отсутствует интерес к обмену культурным опытом, стремление разобраться в межкультурных особенностях субъектов общения; редки случаи проявления инициативы в 
организации межкультурного общения, активность детерминирована изBHe.

Среднему уровню сформированности поликультурной компетентности соответствуют: освоение более половины общего объема подлежащих изучению знаний, их системностью и способностью интерпретировать в профессиональном контексте; нейтральным либо позитивным отношением к межкультурному взаимодействию при недостаточной поведенческой активности, способностью обосновать эти отношения как с позиций своего жизненного опыта, так и с точки зрения культурных ценностей; готовность, (преимущественно, теоретической), к относительно бесконфликтному взаимодействию в поликультурной среде при не достаточных способностях к целенаправленному выстраиванию конструктивных межкультурных взаимоотношений, к проявлению инициативы в данной области социальной жизни.

Высокий уровень поликультурной компетентности характеризуется усвоенными и осмысленными, систематизированными общесоциальными поликультурными знаниями, способностью экстраполировать их в контекст межличностного общения; интересом к культурным особенностям окружающих, стремлением к обогащению собственного культурного опыта через общение с представителями различных культурных групп; активностью и инициативой в межкультурном взаимодействии.

Оценка результатов второго этапа формирования поликультурной компетентности студентов

Диагностика и оценка результатов второго этапа осуществляется с использованием следующего стимульного материала.

1) Список вопросов и заданий для определения системности 
поликультурных знаний студентов:

- Охарактеризуйте коммуникативный компонент педагогической деятельности. Какое значение для конструктивного профессионального взаимодействия имеют культурные сходства и различия?

- В каких ситуациях профессионального взаимодействия культурные различия могут стать препятствием для конструктивного решения общих задач? С какими психологическими особенностями, свойственными представителям разных культур, это связано?

- Какие стили общения Вы знаете? Какой стиль более эффективен при построении общения с младшими школьниками, с их родителями, с коллегами, с администрацией? Почему?

- Каким образом культурные особенности, свойственные представителям иных культурных групп, могут обогатить ваш жизненный / профессиональный культурный опыт?

- Какие молодежные субкультуры Вы знаете? Каким образом они связаны с психологическими закономерностями развития, с особенностями социальной среды, с особенностями семейного воспитания?

- Какие культурные особенности (различия) следует учитывать при взаимодействии с коллегами (преподавателями, администрацией)? Каким образом это влияет на стиль поведения и общения?

- Какие культурные особенности (различия) следует учитывать при взаимодействии с учащимися? Каким образом это влияет на стиль поведения и общения?

- Какие культурные особенности (различия) следует учитывать при организации общения учащихся между собой? Каким образом можно использовать эти особенности для формирования благоприятного психологического микроклимата в ученическом коллективе? 
- Какие культурные особенности (различия) следует учитывать при взаимодействии с родителями учеников? Каким образом это влияет на стиль поведения и общения?

- Охарактеризуйте свое профессиональное окружение с точки зрения поликультурности (по итогам педагогической практики).

2) Стимульный материал для анкетирования и тестирования:

a) Для определения степени осознания студентами социальнопрофессиональной значимости поликультурного взаимодействия использовалось следующее задание: «Оценить по 6-балльной шкале (от 0 до 5) степень значимости для развития педагогической профессии и собственного профессионального развития, для эффективной профессиональной деятельности следующих ценностей: - толерантное отношение к профессиональному мнению коллег, - равные возможности для профессионального самовыражения для представителей разных культур, возрастное, гендерное, идеейное (концептуальное) культурное многообразие педагогического коллектива, - плюрализм профессионально-культурных идей и идеалов, - поликультурность коллектива учащихся, - бережное отношение к культурным различиям учащихся, - учет культурных особенностей коллег при общении с ними, - учет культурных особенностей детей при организации образовательного процесса, - уважительное отношение к родителям учеников, - учет культурных особенностей родителей учащихся, - возможность обмениваться социокультурным опытом с представителями семей учащихся, - возможность обмениваться профессиоанльным опытом с коллегами.

Суммарная оценка варьирует от о до 60 баллов, при этом сумма баллов от 0 до 20 характеризует практически несогласие с социальнопрофессионаьлной значимостью межкультурного взаимодействия, от 21 до 40 баллов - не полное признание социально-профессиональной важности 
межкультурного взаимодействия, от 41 до 60 баллов - полноценное осознание социально-профессиональной значимости межкультурного взаимодействия.

б) Степень ценностного, заинтересованного отношения студентов к межкультурному взаимодействию в процессе профессиональной деятельности определялось по их согласию / не согласию со следующими утверждениями:

1. Чем выше культурное многообразие педагогического коллектива, тем быстрее можно повысить свой профессионализм.

2. Национальные различия детей могут стать основой для развития интереса учащихся друг к другу.

3. Не существует ни каких отличий между девочками и мальчиками в том, по каким критериям они выбирают друзей, поэтому не стоит обращать внимания на гендерный состав ученического коллектива при организации добрых отношений между учащимися.

4. Я не раздражаюсь на замечания старших коллег - у них больше опыта, они могут быть правы.

5. Мне интересны культурные особенности, характерные для семей учащихся.

6. Различия в профессиональных мнениях только сбивают и мешают совершенствовать свое профессиональное мастерство.

7. Общаясь с родителями, следует помнить, что они являются носителями индивидуальных культурных различий.

8. Дети должны понимать и уважать культурные особенности друг друга.

9. Родители ни чем не могут помочь учителям в решении 
образовательных задач.

10. На работе следует обращать внимание только на профессиональный опыт коллег.

11. Решая задачи воспитания в детях коллективизма, необходимо учитывать особенности оценки и выбора друзей, присущие девочкам и мальчикам.

12. Старшие коллеги, чаще всего, критикуют нас только потому, что мы менее опытны, а не потому, что мы действительно не правы.

13. Во взаимодействии с коллегами важно учитывать все их культурные особенности.

14. Национальное разнообразие в детском коллективе мешает дружбе учащихся.

15. Мне важно только социальное положение семей учащихся, их «благополучность».

16.Родителей следует привлекать к решению некоторых задач обучения и воспитания их детей.

17.Дети не должны даже задумываться о культурных различиях между ними.

18. В школе родители - только родители, общение с ними следует строить только с позиции «родитель-учитель».

Согласие с утверждениями №№ 1,2,4,5,7,8,11,13,16 и несогласие с утверждениями №o $3,6,9,10,12,14,15,17,18$ свидетельствуют о наличии интереса и ценностного отношения к межкультурному взаимодействию в профессиональной среде. При этом количество совпадений от 1 до 6 соответствует низкому интересу, от 7 до 12 - среднему, от 13 до 18 сильному. 
в) Выяснение возможных для студентов мотивов профессиональноориентированного межкультурного взаимодействия осуществлялось с помощью контент-анализа выполнения учащимися следующего задания: Напишите, какие мотивы, причины, соображения могли бы побудить (побуждают - нужное подчеркнуть) Вас к активному взаимодействию (деловому и/или личностному общению, совместной деятельности) с представителями иных культурных групп (допускается ответ «никакие»):

- с людьми пенсионного возраста,

- с людьми, на 15-20 лет старше Вас,

- с детьми,

- с подростками,

- с людьми другой национальности,

- с людьми другой религиозной принадлежности,

- с людьми с социальным статусом значительно ниже Вашего,

- с людьми с социальным статусом значительно выше Вашего,

- с коллегами, опирающимися на иные научные концепции.

3) Параметры педагогического наблюдения и экспертной оценки: как в первом этапе, оценивается поведение и деятельность студентов в ситуациях, соответствующих содержанию этапа (общение студентов с преподавателями, участие в научных конференциях, взаимодействие с учителями в период педагогической практики), - оценка результатов педагогической практики: организация общения школьников, диагностика и учет в работе их культурных различий, способность провести анализ социокультурного состава коллектива учащихся, их родителей, педагогического коллектива школы.

Для низкого уровня поликультурной компетентности характерны: 
недостаточная систематизация поликультурных знаний и затруднения при объяснении информации; недостаточно сознательное отношение к оценке собственных мотивов поведения и коммуникативных установок либо доминирование прагматических мотивы межкультурного взаимодействия. Деятельно-поведенческие показатели поликультурной компетентности характеризуются избеганием профессионально-ориентированного межкультурного взаимодействия (пассивность в научно-практической конференции и круглом столе, на педагогической практике) либо низким качеством результатов деятельности.

Средний уровень поликультурной компетентности в когнитивном аспекте характеризуется достаточным объемом при неполной систематизированности поликультурных знаний и неспособностью студентов правильно соотнести базовые знания со сферой профессионального взаимодействия. Профессионально-ориентированное межкультурное взаимодействие (деятельностно-поведенческие характеристики) отличается либо недостаточной активностью, либо нестабильностью результатов. По мотивационно-ценностным характеристикам студенты со средним уровнем поликультурной компетентности отличаются тем, что признают поликультурные ценности как социально значимые, однако не всегда могут определить их роль в профессиональном межкультурном взаимодействии; наличием интереса к межкультурному взаимодействию в этническом и религиозном планах, и полным либо частичным игнорированием иных предметно-содержательных видов культур.

Студенты с высоким уровнем поликультурной компетентности характеризуются большим объемом качественно усвоенных поликультурных знаний, отсутствием либо незначительным количеством затруднений при их объяснении с профессиональных позиций; активным стремлением к 
межкультурным взаимодействиям, всегда или почти всегда подкрепленным поведением и деятельностью, способностью детально описать социокультурные особенности профессионального окружения.

\section{Оценка результатов третьего этапа формирования} поликультурной компетентности студентов

Для диагностики и оценки результатов третьего этапа используется следующий диагностический инструментарий:

1) Список вопросов и заданий для определения системности поликультурных знаний студентов:

- Назовите психологические характеристики детей младшего школьного возраста. Как эти характеристики связаны с базовыми элементами культуры? Дайте культурно-гендерные характеристики младших школьников.

- По каким показателям и какими методами можно выявить поликультурные характеристики ученического коллектива?

- Что такое поликультурное воспитание? C помощью каких форм, средств, методов и приемов возможно осуществление поликультурного воспитания?

- Какие культурные различия можно выделить в среде младших школьников? Каким образом эти различия обусловливают выбор конкретных методических приемов поликультурного воспитания?

- Какое информационное содержание образования целесообразно (возможно) использовать в целях поликультурного воспитания младших школьников? Как отбор содержания связан с поликультурным характером ученического коллектива, с индивидуальными культурными особенностями детей, с их индивидуальной поликультурностью? 
- Как влияют на выбор содержания и успешность осуществления поликультурного воспитания школьников их принадлежность к семьям с разными культурными особенностями? Чем отличаются дети из моноэтнических семей от детей из полиэтнических семей?

- Как влияют на выбор содержания и успешность осуществления поликультурного воспитания школьников реалии социальной жизни, исторические периоды, экономические условия, средства массовой информации? Что можно использовать как средство поликультурного воспитания?

- Какие внеурочные мероприятия можно проводить в целях воспитания межкультурной толерантности у младших школьников?

- Каким образом можно использовать потенциал семейного воспитания в целях поликультурного воспитания младших школьников?

- Какие произведения детской литературы можно использовать в целях поликультурного воспитания младших школьников? Какие культурные (поликультурные) ценности в них отражены?

2) Стимульный материал для анкетирования и тестирования:

а) Степень ценностного, заинтересованного отношения студентов к осуществлению поликультурного воспитания учащихся определялось по их согласию / не согласию со следующими утверждениями:

1. В школе необходимо, прежде всего, учить детей, а также осуществлять нравственное, физическое и эстетическое воспитание, воспитывать в контексте определенной культуры - дело родителей.

2. К решению задач поликультурного воспитания учащихся необходимо серьезно готовиться заранее.

3. Важнее всего - национальное воспитание, интернациональное же - 
на усмотрение родителей.

4. При организации поликультурного воспитания учащихся следует учитывать все национальное многообразие школьников.

5. Социально-статусные особенности семей учащихся не обязательно знать и учитывать в поликультурном воспитании школьников.

6. Дать детям представления о разных культурах и сформировать ценностное отношение к ним - важнейшая задача педагога.

7. Содержание поликультурного воспитания учащихся должно ориентироваться только на интересы государства.

8. Осуществление поликультурного воспитания школьников не требует особой специальной подготовки.

9. Произведения национальной детской литературы могут стать важным средством поликультурного воспитания детей.

10. Внимание поликультурному воспитанию следует уделять и на любых уроках, и во внеурочной работе.

11. Ни какие различия, кроме возрастных, не имеют значения для воспитательной деятельности.

12. При выборе литературных средств поликультурного воспитания необходимо отбирать специально написанные художественные произведения.

13. Поликультурное воспитание учащихся должно строиться на основе национальной культуры, доминирующей в ученическом коллективе.

14. На социально-статусные характеристики семейной культуры учащихся обязательно следует ориентироваться при планировании поликультурного воспитания школьников.

15. Литературные, художественные, спортивные и т.П. интересы детей 
могут определить содержание поликультурного воспитания учащихся.

16. Поликультурное воспитание не стоит включать в круг учебных задач, для этого можно выделить время во внеурочной деятельности.

17.При планировании воспитательной работе учителю необходимо иметь представление о всех культурных различиях детей.

18. Детей необходимо воспитывать в духе интернационализма, равноценности людей всех народов.

Согласие с утверждениями №№ 2,4,6,9,10, 14,15,17,18 и несогласие с утверждениями №№ $1,3,5,7,8,11,12,13,16$ свидетельствуют о наличии интереса и ценностного отношения к межкультурному взаимодействию в профессиональной среде. При этом количество совпадений от 1 до 6 соответствует низкому интересу, от 7 до 12 - среднему, от 13 до 18 сильному.

3) Параметры педагогического наблюдения и экспертной оценки: - как в первом (и втором) этапах с учетом текущих этапных задач в ситуациях, связанных с профессиональной деятельностью в области поликультурного воспитания учащихся, - оценка результатов педагогической практики: внесение поликультурного воспитательного контекста в содержание образования, количество и качество проведения внеурочных мероприятий поликультурного-воспитательного характера.

Студенты с низким уровнем поликультурной компетентности характеризуются теоретической неподготовленностью в области поликультурного воспитания учащихся, а также неспособностью общепедагогические знания соотнести с задачами поликультурного воспитания. Они не считают поликультурное воспитание важной частью педагогической деятельности, формально относятся к выполнению специальных заданий по педагогической практике. 
Студенты со средним уровнем поликультурной компетентности демонстрируют достаточный объем освоенных контекстных знаний, осмысленных и систематизированных, способность воспроизводить усвоенные знания и объяснять их в междисциплинарном аспекте. Они признают социально-профессиональную значимость поликультурных ценностей, важность поликультурного воспитания учащихся, но затрудняются в определении собственных мотивов поликультурного взаимодействия и поликультурного воспитания школьников. Результаты реального межкультурного профессионально-ориентированного взаимодействия данного контингента отличаются непостоянством качества, а деятельность - то активностью и инициативой, то - пассивностью, либо активностью, детерминируемой внешними обстоятельствами (контроль работы педагогом, например).

Студенты с высоким уровнем поликультурной компетентности отличаются тем, что поликультурные знания освоены ими в полном или почти полном объеме, осознаны и систематизированы; эти учащиеся проявляют способность экстраполировать теоретические знания в контекст реальной (или гипотетической, но конкретной) ситуации, применять их на практике. Поликультурные ценности осознаны ими как личностно значимые - и для жизни в обществе, и для эффективной профессиональной деятельности; интерес культурным различиям и стремление к межкультурному взаимодействию достаточно стабильны. Поведение и деятельность характеризуются активным, внутренне детерминированным участием в межкультурном взаимодействии, проявлением инициативы, устойчивым достижением запланированных позитивных результатов. 


\section{PEЗЮME}

Поликультурная подготовка будущих педагогов является актуальной педагогической задачей, и предполагает организацию в системе профессионально-педагогического образования целенаправленную деятельность в двух взаимосвязанных направлениях:

- общесоциальное - теоретическая, мотивационная и практическая подготовка студентов к жизни и конструктивному межличностному взаимодействию в поликультурном обществе;

- профессиональное - теоретическая, мотивационная и практическая подготовка студентов к конструктивному межкультурному взаимодействию с субъектами педагогической деятельности и к осуществлению образовательного процесса с опорой на идеи поликультурного образования.

Результатом поликультурной подготовки должна стать поликультурная компетентность будущих педагогов, которая представляет собой интегративное личностно-профессиональное качество, обусловливающее его способность эффективно участвовать в социальных процессах поликультурного общества, осуществлять межкультурное взаимодействие, учитывать поликультурный состав субъектов профессиональной деятельности и использовать его характеристики и особенности для решения педагогических задач, а также осуществлять поликультурное воспитание учащихся.

Поликультурная компетентность педагога включает профессиональное и общесоциальное содержание, структурно представленное как совокупность когнитивного (поликультурные знания и теоретические умения), мотивационно-ценностного (поликультурные ценности, толерантные отношения, установки на межкультурное взаимодействие) и деятельностноповеденческого (навыки общения, поведения и деятельности в условиях поликультурного общества) компонентов. Структурным компонентам 
соответствуют критерии сформированности поликультурной компетентности: - когнитивные (полноценная система поликультурных знаний, освоенных в полном объеме на уровне применения и творчества), мотивационно-ценностные (осознание и принятие студентами социальнопрофессиональной значимости поликультурных ценностей, наличие прочного интереса к иным культурам и стремление к межкультурному взаимодействию является мотивационно-ценностным критерием сформированности поликультурной компетентности) и деятельностноповеденческие (активность студентов в межкультурном взаимодействии, культурная адекватность их поведения, успешность предпринимаемых действий). Степень соответствия индивидуально-личностных характеристик выделенным критериям обусловливает уровни сформированности поликультурной компетентности: высокий, средний или низкий.

Эффективность формирования поликультурной компетентности будущих педагогов обеспечивается системой психолого-педагогических условий:

- опора на основные положения теории поликультурного образования: открытость, культурный плюрализм, диалог культур, контекстность, деятельностное освоение культуры;

- опора на основные положения компетентностного подхода: организация контекстной деятельности студентов, - стимулирование активности студентов посредством применения инновационных средств и методов, - использование оценочных процедур, адекватных структуре, содержанию и критериям поликультурной компетентности, - направленность содержания образования на формирование всех содержательных и структурных компонентов поликультурной компетентности, - учет личных интересов и склонностей студентов при выборе содержания образования,

- выбор средств, методов, форм образования, соответствующих методологическим характеристикам компетентностного подхода: - активно - 
деятельностная направленность образования, - ситуативно-проблемная организация образовательного процесса, - конструирование содержания образования в соответствии с идеями задачного и функционального подходов к образованию,

- опора на ролевую теорию личности при организации формирования поликультурной компетентности студентов,

- интегративный подход к организации образовательного процесса.

В организационно - процессуальном плане формирование поликультурной компетентности студентов предполагает последовательность следующих этапов: социально-личностного (цель освоение студентами общесоциального содержания поликультурной компетентности, становление их готовности и способности к эффективной жизнедеятельности (общению, решению общесоциальных коммуникативных задач) в условиях поликультурного общества), переходного (цель экстраполяция общесоциального содержания поликультурной компетентности в сферу профессиональной деятельности, становление готовности и способности студентов к эффективному педагогическому взаимодействию с учетом поликультурности профессионального сообщества) и профессионально-личностного (цель - полноценное освоение студентами педагогического содержания поликультурной компетентности, становление их готовности и способности к осуществлению поликультурного воспитания учащихся), соответствующих предметному содержанию поликультурной компетентности педагога.

На каждом этапе решаются задачи, связанные с развитием когнитивной, мотивационно-ценностной и деятельностно-поведенической сфер личности студентов, конкретизируются критерии и уровни сформированности поликультурной компетентности студентов, осуществляется отбор когнитивного содержания образования, разработка ситуативно-проблемных задач, подбор средств, методов и форм организации 
образовательного процесса. Кроме того, предусматривается возможность диагностировать динамику запланированных личностных изменений путем использования адекватных методов диагностики, специально разработанных тестовых заданий, опросников, анкет, соответствующих содержанию этапов.

Описанные в монографии психолого-педагогические условия формирования поликультурной компетентности будущих педагогов были апробированы путем соответствующей организации образовательного процесса на педагогическом факультете филиала Адыгейского государственного университета г.Кошехабля.

Результаты опытно-экспериментальной работы однозначно свидетельствовали об адекватности выявленной системы психологопедагогических условий поставленной образовательной цели. К окончанию формирующего эксперимента студенты экспериментальной группы характеризовались достоверно более высоким уровнем поликультурной компетентности, чем представители контрольной группы: 30,9\% - высокий уровень (КГ - 12,4\%), 67,3\% - средний уровень (КГ - 42,8\%); низкий уровень поликультурной компетентности зафиксирован у 1,8\% студентов, тогда как в КГ таких учащихся оказалось 44,8\% $(\mathrm{P}<0,05)$. 


\section{СПИСОК ИСПОЛЬЗОВАННОЙ ЛИТЕРАТУРЫ}

1. Адольф, В.А. Профессиональная компетентность современного учителя: монография / В.А. Адольф; Мин-во общего и проф. образ. РФ, Краснояр. гос. ун-т. - Красноярск, 1998. - 51 с.

2. Алешина, И.В. Культурные различия: критерии, содержание и значение в ПР [Электронный ресурс] / И.В.Алешина. - Режим доступа: http://polbu.ru/aleshina_pr/ch43_i.html

3. Амосов, М.Н. Моделирование сложных систем / М.Н.Амосов. Киев, 1968.

4. Андреев, А.П. Педагогика: Учебный курс для творческого саморазвития / А.П.Андреев. - Казань: Центр инновационных технологий, 2000.

5. Антилогова, Л.Н. О взаимосвязи ценностных ориентаций и нравственной активности личности / Л.Н.Антилогова // Сборник «Сибирская психология сегодня: Сборник научных трудов». - Вып. 2. - Кемерово: Кузбассвузиздат, 2003. - 410 с.

6. Артюхова, И.С. Ценности и воспитание / И.С.Артюхова // Педагогика. - 1999. - № 4. - С. 117 - 120.

7. Асеев, В.Г. Мотивация поведения и формирования личности / В.Г.Асеев. - М., 1983. - 46c.

8. Атласова, О.М. Развитие профессиональной компетентности руководителей школ в процессе повышения квалификации: автореф...дисс.канд.пед.наук / О.М.Атласова. - СПб, 1995.

9. Байденко, В.И. Компетенции: к освоению компетентностного подхода: материалы к первому заседанию методологического семинара 20 мая 2004 г. - М.: Исслед. центр проблем качества подготовки специалистов, 2004. - 30c. 
10.Байденко, В.И. Болонский процесс: структурная реформа высшего образования Европы / В.И.Байденко. - М.: Исследоват.центр проблем качества подготовки специалистов, 2002. - 128c.

11.Балл, Г.А. Теория учебных задач: психолого-педагогический аспект / Г.А.Балл. -М., 1990.

12.Барменкова, О.И. Эффективные приемы обучения английскому языку: пособие для учителя / О.И. Барменкова. - Пенза, 1997.Э17

13.Басова, Н.В. Педагогика и практическая психология / Н.В.Басова. Ростов н/Д: «Феникс», 2000.

14.Батомункуева, Т.П. Проблемы и перспективы толерантного воспитания [Электронный ресурс] / Т.П. Батомункуева. - Режим доступа: http://buryatia.fio.ru/tolerance/1/public/ essay.htm

15.Бахтин, Л.М. Два способа изучать культуру / Л.М.Бахтин // Вопросы философии. - 1986. - № 12.

16.Белавина, С.В. Ситуационный подход в различных научных сферах и областях деятельности [Электронный ресурс] / С.В.Белавина. - Режим доступа: http://www.labex.ru/page/krim_sit_1.html

17.Белкин, А.С. Теория и практика витагенного обучения / А.С.Белкин. -Екатеринбург, 1997.

18.Белогуров, А.Ю. Фактор поликультурности в контексте этнонациональной стратегии развития российского образования [Электронный pecypc] / Ю.А.Белогуров. - Режим доступа: http://abelogurov.narod.ru/works/text1.html

19.Бермус, А.Г. Концептуальные и методологические основы педагогической поддержки в поликультурном социально-воспитательном пространстве [Электронный ресурс] / А.Г.Бермус. - Режим доступа: http://rspu.edu.ru/science/conferences/01_04_09/2bermus.html

20.Беспалько, В.П. Слагаемые педагогической технологии / В.П.Беспалько. - М: Педагогика, 1989. - 190 с. 
21.Библер, В.С. Диалог. Сознание. Культура / В.С.Библер. - М., 1989.

22.Библер, В.С. Культура. Диалог культур / В.С.Библер // Вопросы философии. - 1989. - № 6. - С. 33.

23.Библер, В.С. Философско-психологические предположения Школы диалога культур / В.С.Библер. - М., 1998.

24.Блауберг, И.В., Юдин, Э.Г. Становление и сущность системного подхода / И.В.Блауберг, Э.Г.Юдин. - М., 1973.

25.Бобиенко, О.М. Компетентностно-ориентированный подход в образовании взрослых: учеб. пособие / О.М. Бобиенко, 3.Н. Сафина. Казань: Изд-во ТИСБИ, 2004. — 90 с.

26. Бодалев, А.А. Психология о личности / А.А. Бодалев. - М.: МГУ, 1988. $-63 \mathrm{c}$.

27.Бондарева, Е.В. Направленность на формирование профессиональной компетентности как путь совершенствования экономического образования / Е.В. Бондарева. - Волгоград: Изд-во ВГУ, 2005.

28.Бондаренко, Н.Ю. Становление экзистенциальных ценностей будущих учителей в процессе интерактивного обучения: автореф.дисс...канд.пед.наук / Н.Ю.Бондаренко. -Ростов-на-Дону, 2006.

29.Бордовская., Н.В., Реан, А.А. Педагогика: Учебник для вузов / Н.В.Бордовская, А.А.Реан. - СПб: Издательство “ Питер”, 2000. - 304 с. (Серия «Учебник нового века»).

30.Борисова, Е. М. О роли профессиональной деятельности в формировании личности / Е.М. Борисова // Психология формирования и развития личности / ред. Л.И. Анцыферова. - М., 1981. - С. 159-177.

31.Борисова, Е.М. Проект на уроках немецкого языка / Е.М. Борисова. // ИЯШ. - 1992. - №2. - С.15-19.Э30

32.Брушлинский, А.В. Проблема психологии субъекта / А.В.Брушлинский. - М., МГУ, 1994. 
33.Бумке, О. Культура и вырождение [Электронный ресурс] / О.Бумке. - Режим доступа: http://www.booklove.ru/pus_139055.html

34.Васютенкова, И.В. Сущностные аспекты и актуальность поликультурного образования в современных условиях [Электронный pecypc] / И.В.Васютенкова. - Режим доступа: http://new.loiro.ru/index.php

35.Введенский, В.Н. Моделирование профессиональной компетентности педагога // Педагогика. - 2003. - №10. - С. 51-55

36.Веденина, Л.Г. Межкультурное обучение как полилог языков и культур / Л.Г.Веденина // Межкультурная коммуникация: Тезисы докладов. Иркутск, 1993.

37.Верб, М.А. Эстетическая культура школьника: курс лекций для студентов и учителей / М.А.Верб. - СПб., 1997.

38.Верб, М.А. Эстетические потребности и духовное развитие личности: В помощь лектору / М.А.Верб. - Л., 1981.

39.Вербицкий, А.А. Концепция знаково-контекстного обучения в вузе // Вопросы психологии. - М. - 1987. - № 5. - С.31-39.

40.Виленский, М.Я. Ценности физической культуры и их интериоризация учащимися [Электронный ресурс] / М.Я.Виленский. - Режим доступа: http://spo.1september.ru/articlef.php

41.Вилюнас, В.К. Психологические механизмы мотивации человека / В.К.Вилюнас. - М.: Изд-во МГУ, 1990. - 288с.

42.Виолле-ле-Дюк, Э. Э. Жизнь и развлечения в средние века / Э.Э. Виолле-ле-Дюк. - СПб., 1997.

43.Волчецкая, Т.С. Криминалистическая ситуалогия [Электронный pecypc] / Т.С.Волчецкая. - Режим доступа: http://www.vusnet.ru/forum/

44.Выжлецов Г.П. Аксиология культуры / Г.П.Выжлецов. - СПб.: СПб университет, 1996. - 152 с.

45.Гальперин, П.Я. Введение в психологию: учеб. пособие для вузов / П.Я. Гальперин. - М, 1993. 
46.Глебов, А.А. Воспитание патриотизма, толерантности и культуры межнационального общения: Учеб. Пособие / А.А.Глебов. - Волгоград: Перемена, 2004.

47.Глемба, Д.С., Грачев, И.А. Образовательный уровень в поликультурной стране [Электронный ресурс] / Д.С.Глемба, И.А.Грачев. Режим доступа: http://www.mogk.ru/modules/journal.php

48.Гречко, П.К. Конфликт, терпимость, толерантность / П.К.Гречко // Поликультурное общество: стабильность и коммуникация. - М.: "УникумЦентр", 2003.

49.Гришанова, Н.А. Развитие компетентности специалистов как важнейшее направление реформирования профессионального образования / Н.А. Гришанова // Квалиметрия в образовании: методология и практика: материалы Х Симпозиума. Кн.6. - М.: Изд-во Исслед. центра проблем качества подготовки специалистов, 2002.

50.Громцева, А.К. Формирование у школьников готовности к самообразованию: Учебное пособие по спецкурсу для студентов пед.институтов / А.К.Громцева. -М.: Просвещение, 1983. - 144c

51.Грушевицкая, Т.Г., Попков, В.Д., Садохин, А.П. Основы межкультурной коммуникации: учебник для вузов / под ред.Садохина А.П. M., 2002.

52.Гурьянова, Т.Ю. Формирование поликультурной компетентности студентов ссузов (на материале обучения иностранному языку): автореф. дисс...канд.пед. наук / Т.Ю.Гурьянова. - Чебоксары, 2008.

53.Давидович, В.Е., Жданов Ю.А. Сущность культуры / В.Е.Давидович, Ю.А.Жданов. - Ростов н/Д: Изд-во Ростовского университета, 1978. - $264 \mathrm{c}$.

54.Давыдов, В.В. Проблемы развивающего обучения / В.В.давыдов. M., 1986. 
55.Данилова, Л. Формирование поликультурной компетентности студентов [Электронный ресурс] / Л.Данилова. - Режим доступа:

\section{http://uchitel2.valuehost.ru/journal/journ03-07/journ03-07p1.html}

56.Делор, Жак. Доклад международной комиссии по образованию, представленный ЮНЕСКО «Образование: сокрытое сокровище». - М.: ЮНЕСКО, 1997.

57.Деньгуб, Е.С. Поликультурное образование личности как способ воспитания гражданственности и общественно значимых мнений [Электронный pecypc] / Е.С.Деньгуб. - Режим доступа: http://www.prof.msu.ru/publ/omsk2/o30.htm

58.Джуринский, А.Н. Воспитание в России и за рубежом [Электронный pecypc] / А.Н.Джуринский. - Режим доступа: http://old.prosv.ru

59.Дистервейг, А. Избр. Пед. Соч. / А.Дистервейг - М.: Просвещение, 1956.

60.Дмитриев, Г.Д. Многокультурное образование / Г.Д.Дмитриев. - М.: Народное образование, 1999.

61.Дюркгейм, Э. Социология образования / Э.Дюркгейм. - М., 1996.

62.Еремкина, О.В. Профилирование культурологической подготовки менеджеров по туризму: автореф.дисс...пед.наук / О.В.Еремкина. - Сочи, 2001.

63.Зеер, Э.Ф Компетентностный подход к образованию [Электронный pecypc] / Э.Ф.Зеер. - Режим доступа: http://www.urorao.ru/konf2005.php

64.3еep, Э.Ф. Модернизация профессионального образования: компетентностный подход / Э.Ф. Зеер // Образование и наука. - 2004. - № 3 (27).

65.Зимняя, И.А. Ключевые компетентности как результативно-целевая основа компетентностного подхода в образовании. Авторская версия / И.А.Зимняя. - М.: Исследовательский центр проблем качества подготовки специалистов, 2004. 
66.Зимняя, И.А. Ключевые компетенции - новая парадигма результата образования / И.А. Зимняя // Высшее образование сегодня. 2003. - № 5. - C. 34-42.

67.Исаев, В.А. Образование взрослых: компетентностный подход: монография / В.А.Исаев. - Великий Новгород, 2005.

68.Кабуш, В.Т. Формирование гуманистической системы воспитания / В.Т.Кабуш. - М., 1996.

69.Каган М.С. Философская теория ценности / М.С.Каган. - СПб.: ТОО ТК "Петрополис", 1997. - 205 с.

70.Клюева, Н.Н. Проектная методика - одна из активных форм обучения английскому языку // Н.Н. Клюева. - Новосибирск, 2005.

71.Ковалев, А.Г. Психология личности / А.Г. Ковалев. - 3-е изд., перераб. и доп. - М., 1970.

72.Коган, Л.Н. Всестороннее развитие личности и культура / Л.Н.Коган. - М.: Знание, 1981.-63с.

73.Коган, М.С. Человеческая деятельность. Опыт системного исследования / М.С.Коган. - М.: Политиздат, 1974. -328c.

74.Коган, М.С. Системный подход и гуманитарные знания / М.С.Коган. - Л., 1991.

75.Коган, М.С. Философия культуры / М.С.Коган. - СПБ, 1996.

76.Коджаспирова, Г.M. Педагогика: учебник для студ.образоват.учреждений сред.проф.образования / Г.М.Коджаспирова. -М.: Гуманит.изд.центр ВЛАДОС, 2003.

77.Коджаспирова, Г.М., Коджаспиров, А.Ю. Педагогический словарь: Для сту.высш.и сред.пед.учеб.заведений / Г.М.Коджаспирова, А.Ю.Коджаспиров. - М.: Издательский центр «Академия», 2005. - 176 с.

78.Колесникова, И.А. Коммуникативная деятельность педагога: учеб.пособие для студ.высш.пед.учеб.заведений . - М.: Издательский центр «Академия», 2007. - 336 с. 
79.Копылова, В.В. Методика проектной работы на уроках английского языка / В.В. Копылова. - М., 2003.

80.Костомаров, Н.И. Очерк домашней жизни и нравов великорусского народа в XVI и XVII столетиях / Н.И.Костомаров. - М., 1992.

81.Кравченко, А.И. Общая социология: Учебник для вузов. М.:Юнити,2002

82.Кузнецова, Т.Ф. Историзм и тезаурусный анализ культуры / Т.Ф.Кузнецова. - Электронный журнал "Знание. Понимание. Умение". - №9. - 2008 - Комплексные исследования: тезаурусный анализ мировой культуры.

83. Кузьмина, Н.В. Формирование педагогических способностей / Н.В. Кудрявцев. - Л., 1961.

84.Культурология. История мировой культуры: Учебное пособие / Под ред. Т.Ф. Кузнецовой. - М.: Издательский центр "Академия", 2003.- 607 с.

85.Курашинова, А.Х. Развитие профессионального мышления педагога в условиях задачной формы организации учебного процесса: автореф.дисс...канд.пед.наук / А.Х.Курашинова. - Майкоп, 2007.

86.Курвина, А.В. Реализация интегративного подхода к профильному обучению старшеклассников (культурологический аспект) [Электронный pecypc] / А.В.Курвина. - Режим доступа: http://tsu.tmb.ru/culturology/journal/6/kurvina_5_2006-2.htm

87.Лазарев, Н.А. Теоретико-методологические основы развития личности студентов с опорой на их религиозно-духовные гуманистические ценности: автореф.дис. ... д-ра пед. наук / Н.А.Лазарев. - М., 2001.

88.Леднев, В.С. Содержание образования: сущность, структура, перспективы / В.С.Леднев. -М.:Высшая школа, 1991.

89.Леонтьев, А.М. Акмеологический подход как фактор повышения качества профессиональной подготовки учителя безопасности жизнедеятельности: автореф.дисс...канд.пед.наук / А.М.Леонтьев. - Майкоп, 2007. 
90.Лернер, И.Я. Дидактические основы методов обучения / И.Я.Лернер. -М., 1981.

91.Лихачев, Б.Т. Введение в теорию и историю воспитательных ценностей / Б.Т.Лихачев. -Самара, 1997.

92.Лотман, Ю.М. Беседы о русской культуре [Электронный ресурс] / Ю.М.Лотман. - Режим доступа: http://yanko.lib.ru/add/lotman-all.htm

93.Лотман, Ю.М. Культура и взрыв / Ю.М.Лотман. - М., 1992.

94.Лурия, А.Р. Этапы пройденного пути: Научная автобиография / А.Р.Лурия // Глава Культурные различия и интеллектуальная деятельность. М.: Изд-во Моск. ун-та, 1982. - С. 47-69.

95.Макрушина, И.В. Сущность и структура экологического сознания / И.В. Макрушина, С.Н. Бегидова // Проблемы современной педагогики и системы образования: сб. материалов Всероссийской научно-практической конференции. Т.2 / под ред. С.Н. Бегидовой - Майкоп: Изд-во АГУ, 2004. С. 124-132.

96.Максимова, В.Н. Интеграция в системе образования / В.Н. Максимова. - СПб, 1991. - 84 с.

97.Мальковская, И.А. Глобализация и транскультурный вызов незападного мира [Электронный ресурс] / И.А.Мальковская. - Режим доступа: http://www.isras.ru/files/File/Socis/12-2005/malkovskaya.pdf

98.Маркарян, Э.С. Культурная традиция и задача дифференциации ее общих и локальных проявлений / Э.С.Маркарян // Методологические проблемы этнических культур: Мат. симпозиума. - Ереван: Изд-во АН ACCP, 1978.

99.Маркарян, Э.С. Теория культуры и современная наука / Э.С.Маркарян. - М.: Мысль, 1983.

100. Матюхина, Е. Н. Культура как основа коммуникации / Е.Н. Матюхина // Language and Literature. - Вып. 20. - 2004 
101. Махмутов, М.И. Организация проблемного обучения в школе / М.И.Махмутов. - М., 1977.

102. Мачехина, О.Н. Педагогические условия развития социальной компетентности старшеклассников: проектно-контекстный подход: автореф.дисс...канд.пед.наук / О.Н.Мачехина. - Москва, 2007.

103. Менская, Т.Б., Поликультурное образование: Программы и методы // Общество и образование в современном мире: Сб. материалов из зарубежного опыта. - Вып. 2. - М., 1993.

104. Меретукова, З.К. Педагогическая культура и педагогический идеал: Учебное пособие для студентов и аспирантов / З.К.Меретукова. Майкоп, 1999. - 160 с.

105. Митина, Л.М. Психология развития конкурентоспособной личности / Л.М.Митина. - М.: Московский психолого-социальный институт, 2002. - 400c.

106. Мулин, В.М. Дидактические игры как средство повышения квалификации педагогических кадров по физической культуре/ В.М.Мулин, С.В.Лемаев, Н.Н.Сурина // Сборник статей «Проблемы физического воспитания учащейся молодежи». -Карачаевск, 1991

107. Неверкович, С.Д. Игровые методы подготовки кадров: Учеб.пособ./ С.Д.Неверкович // Под ред.В.В.Двыдова. - М.: Высш.шк., 1995.

108. Нечаева, Е.А. Подготовка педагога к профессиональной деятельности в мультикультурном коллективе учащихся: автореф.дисс...канд.пед.наук / Е.А.Нечаева. - Калининград, 2008.

109. Нудько, В.А. Формирование гуманистических ценностных ориентаций студентов (на примере изучения иностранного языка в вузе): автореф.дисс...канд.пед.наук / В.А.Нудько. - Ульяновск, 2006.

110. Общая социология: Систем. Курс: Учеб пособие / Ю.Н. Аксененко и др.// Под ред. Г.В. Дыльнова. 2-е изд.,перераб., доп. Саратов: СЮИ МВД России,1999. 
111. Олифер, В. Новые технологии в обучении / В. Олифер, Н. Олифер. - СПб., 2000.

112. Парфенов, В.А. Повышение квалификации физкультурных кадров / Теория и практика физической культуры. - М. - 1984. - № 6. - С.4446.

113. Парыгин, Б.Д. Социально-психологический климат коллектива: Пути и методы изучения / Б.Д.Парыгин. - Л., 1981.

114. Педагогика открытости и диалога культур / Под ред. М.Н. Певзнера, В.О. Букетова, О.М. Зайченко. - М.: Исследовательский центр проблем качества подготовки специалистов, 2000.

115. Петровская, Л.А. Компетентность в общении / Л.А.Петровская. M., 1989.

116. Пиаже, Ж. Избранные психологические труды / Ж.Пиаже. - М., 1994.

117. Плужник, И.Л. Формирование межкультурной коммуникативной компетенции студентов гуманитарного профиля в процессе профессиональной подготовки: автореф.дисс...д-ра пед.наук / И.Л.Плужник. - Тюмень, 2003.

118. Поляков, Л.В. Обществознание. Книга для учителя [Электронный pecypc ] / Д.В.Поляков. - Режим доступа: http://www.prosv.ru/umk/obshestvoznanie/3.html

119. Попков, В.А. Критический стиль мышления в профессиональном самостановлении преподавателя высшей школы: автореф.дисс...д-ра пед.наук / В.А.Попков. - М., 2002. - 42 с.

120. Проблемы повышения компетентности руководителей школ / Под ред.Е.П.Тонконогой. - Л.: ИОВ, 1989.

121. Рабинович, Ф.М. Интенсивные методы обучения и средняя школа / Ф.М. Рабинович, Т.В. Сахарова // Иностранные языки в школе. - 1991. - № 1. - C.9. 
122. Равен, Дж. Компетентность в современном обществе: выявление, развитие и реализация // Дж.Равен - М.: «Когито-Центр», 2002. - 396 с.

123. Равен, Дж. Педагогическое тестирование: Проблемы, заблуждения, перспективы / Дж.Равен. - М.: «Когито-Центр», 2001. - 142 с.

124. Реан, А.А., Коломинский, Я.Л. Социальная педагогическая психология / А.А.Реан, Я.Л.Коломенский. - СПБ.: Питер, 2000.

125. Рерих, Н. К. Культура и цивилизация / Н.К.Рерих. - М.: Международный Центр Рерихов, 1994. - 148 с.

126. Реформы образования в современном мире: глобальные и региональные тенденции / Под ред. Б.Л.Вульфсона. - М.: Изд-во РОУ, 1995.

127. Розум, С.И. Психология социализации и социальной адаптации человека / С.И.Розум. - СПб: Речь, 2006. - 365 с.

128. Руденко,Н.Н., Руденко,В.Н. Конфликтологическая культура как компонент поликультурного образования / Н.Н.Руденко, В.Н.Руденко. -

129. Рывкина, Р.В. Постсоветское пространство как генератор конфликтов / Р.В.Рывкина / /СОЦИС. - 1999. -№5. - С.12.

130. Савина, Ю.Г. Формирование ценностных ориентаций учащейся молодежи средствами декоративно-прикладного искусства: автореф.дисс...канд.пед.наук / Ю.Г.Савина. - М, 2006. - 23 с.

131. Сафина, 3.Н. Ключевые компетенции как компонента модели специалиста [Электронный ресурс] / 3.Н.Сафина. - Режим доступа: http://www.tisbi.ru/science/vestnik/2001/issue1/vest1_4\%5B4\%5D.html

132. Селевко, Г.К. Альтернативные педагогические технологии / Г.К.Селевко. - М.: НИИ школьных технологий, 2005. - 224c.

133. Селиванов, В.С. Основы общей педагогики: Теория и методика воспитания: Учеб.пособие для студ.высш.пед.учеб.заведений / Под ред. В.А.Сластенина. -2-е изд., испр. - М.: изд-й центр «Академия», 2002. - 336с.

134. Скаткин, М.Н. Совершенствование процесса обучения / М.Н.Скаткин. - М., 1971. 
135. Сластенин, В.А., Чижакова, Г.И. Введение в педагогическую аксиологию: Учеб. пособие для студ.высш.пед.учеб.заведений. В.А. Сластение, Г.И. Чижакова - М.: Издательский центр «Академия», 2003. $-192 \mathrm{c}$.

136. Смелзер, Н. Социология / Н.Смедзер. - М., 1994.

137. Соколов, Э.В. Культурология / Э.В.Соколов. - М., 1994.

138. Соколов, Э.В. Культура и личность / Э.В.Соколов. - Л., 1972.

139. Сорокин, П. Человек. Цивилизация. Общество / П.Сорокин. - М., 1992.

140. Столяренко, А.М. Психология и педагогика: Учеб.пособие для вузов / А.М.Столяренко. - М.: ЮНИТИ-ДАНА, 2001. - 431с.

141. Столяренко, А.М. Психология и педагогика: Учеб.пособие для вузов / А.М.Столяренко. -М.: ЮНИТИ-ДАНА, 2001.

142. Столяренко, Л.Д., Самыгин, С.И. Педагогика. 100 экзаменационных ответов. Экспресс-справочник для студентов вузов / Л.Д.Столяренко, С.И.Самыгин. - Ростов н/Д: Издательский центр «МарТ», 2001.

143. Стратегия модернизации содержания общего образования. Материалы для разработки документов по обновлению общего образования. — M., 2001.

144. Супрунова, Л.Л., Белогуров, А.Ю. Национально-региональный компонент содержания общего образования в структуре поликультурного образования // Развитие личности в образовательных системах южнороссийского региона. - Рос-тов-на-Дону: РГПУ. - Часть II. - 2000.

145. Таланчук, Н. М. Системно-синергетическая теория воспитания / Н.М.Таланчук // Профессиональная педагогика: Учебник для студентов, обучающихся по педагогич. специальностям и направлениям. - М., 1997.

146. Тарасов, Е.Ф., Сорокин, Ю.А. Национально-культурная специфика речевого и неречевого поведения / Е.Ф.Тарасов, Ю.А.Сорокин. - 
В кн.: Национально-культурная специфика речевого поведения. - М.: Наука, 1977.

147. Татур, Ю.Г. Компетентность в структуре модели качества подготовки специалистов / Ю.Г. Татур // Высшее образование сегодня. 2004. - № 3. - С. 20-26.

148. Тейлор, Э.Б. Первобытная культура / Э.Б.Тейлор. - 1989 . ICС Web

149. Тен, Ю.П. Символ в межкультурной коммуникации: автореф.дисс...канд.философ.наук / Ю.П.Тен. - Ростов-на-Дону, 2008 .

150. Теория культуры: Учебное пособие / Под ред. С. Н. Иконниковой, В. П. Большакова.— СПб.: Питер, 2008. - 592 с.

151. Терещенко, А. Быт русского народа / А.Терещенко. - М., 19971999. - Ч. 1-5.

152. Торгашина, Т.И. Научно-исследовательская работа студентов педагогического вуза как средство развития их творческого потенциала: дис. ... канд. пед. наук / Т.И. Торгашина. - Волгоград, 1999.

153. Тутарищева, С.M. Формирование готовности будущих специалистов к научно-исследовательской деятельности в профессиональной сфере (на примере специальности - юриспруденция): автореф.дисс...канд.пед.наук / С.М.Тутарищева. - Майкоп, 2005.

154. Тюников, Ю.С. Методика выявления и описания интегрированных процессов в учебно-воспитательной работе / Ю.С. Тюнников. - СПб.: СПбГУ, 1987. - 47 с.

155. Уледов, А.К. Духовная жизнь общества / А.К.Уледов. -М.: Просвещение, 1986.

156. Ушинский, К.Д. О нравственном элементе в воспитании / К.Д.Ушинский. -М.: Просвещение, 1978. 
157. Федорова, Е.Ф. Признаки направленности содержания самостоятельной работы студентов на становление их готовности к самообразованию: автореф.дисс...канд.пед.наук / Е.Ф.Федорова. -Челябинск, 1999.

158. Федюнина, С.М. Концептуальные основания и условия мультикультуризма в современном российском обществе: автореф.дисс...докт.социол.наук / С.М.Федюнина. - Саратов, 2007.

159. Философские проблемы теории адаптации / Ред. А.Б. Георгиевский и др. - М., 1975.

160. Формирование системного мышления в обучении: Учеб. Пособие для вузов / Под ред. проф. 3.А. Решетовой. - М.: ЮНИТИ - ДАНА. 2002. $344 \mathrm{c}$.

161. Формирование у учащихся готовности к самообразованию / Под ред. Б.Ф.Райского. - Волгоград, 1975. - 208с.

162. Фукс, Э. Иллюстрированная история нравов: Буржуазный век / Э.Фукс. - М., 1994.

163. Фукс, Э. Иллюстрированная история нравов: Галантный век / Э.Фукс. - М., 1994.

164. Фукс, Э. Иллюстрированная история нравов: Эпоха Ренессанса / Э.Фукс. - М, 1993.

165. Хазова, С. А. Психолого-педагогические условия организации аксиологического подхода в подготовке будущих педагогов [Электронный pecypc] / С. А. Хазова // Режим доступа: http://www.fan-nauka.narod.ru/20081.html

166. Хазова, С.А. Формирование опыта профессионально-творческого мышления у будущих специалистов по физической культуре и спорту: автореф.дисс...канд.пед.наук / С.А.Хазова. - Майкоп, 2004. - 25 с. 
167. Хазова, С.А., Карягина, Н.В. Игровые технологии обучения в подготовке специалистов по физической культуре и спорту: Монография / С.А.Хазова, Н.В.Карягина // Под общ.ред. Н.Х.Хакунова. - Майкоп, 2008. -

168. Хазова1, С.А. Профессиональная компетентность специалистов по физической культуре и спорту как показатель их конкурентоспособности / ФК: воспитание, образование, тренировка - № 1. -2008, -С.50-54

169. Харчев, А.Г. Социология воспитания. Проблемы воспитания личности / А.Г.Харчев. - М.: «Политиздат», 1990.

170. Хомский, Н. Аспекты теории синтаксиса / Н.Хомский. - М., 1972 (англ. 1965).)

171. Хуторской, А.В. Ключевые компетенции как компонент личностно-ориентированной парадигмы //Народное образование. - 2003. - № 2. - C. 58-64.

172. Чавчавадзе, Н.3. Гуманитарная культура как фактор преобразования России / Н.З.Чавчавадзе. -СПб., 2000.

173. Чавчавадзе, Н.3. Культура и ценности / Н.З.Чавчавадзе // Культура в свете философии. - Тбилиси, 1979.- С.31-72.

174. Чапаев, Н.К. Структура и содержание теоретикометодологического обеспечения педагогической интеграции: автореф.дис... д-ра. пед. наук / Н.К. Чапаев. - Екатеринбург, 1998.

175. Чернилевский, Д.В. Дидактические технологии в высшей школе: Учеб.пособие для вузов / Д.В.Чернилевский. -М.: ЮНИТИ-ДАНА, 2002.

176. Шаймарданов, И. Социологические подходы к изучению культуры: Структурно-функциональный подход [Электронный ресурс] / И.Шаймарданов. - Режим доступа: http://sociologist.nm.ru/articles/research_01.htm

177. Шапарь, В.Б. Новейший психологический словарь / В.Б.Шапарь. - Ростов н/Д.: Феникс, 2005. - 808 с.

178. Шафрикова, А.В. Мультикультурный подход в обучении и 
воспитании школьников: автореф.дисс...канд.пед.наук / А.В.Шафрикова. Казань, 1998.

179. Шишов, С.Е., Кальней, В.А. Школа: мониторинг качества образования / С.Е.Шишов, В.А.Кальней. - М.: Пед.об-во России, 2000. - 320 c.

180. Шрагина, Л.И., Меерович, М.И. Смена парадигмы методологии как способ разрешения противоречия в системе образования [Электронный ресурс] / Л.И.Шрагина, М.И.Меерович. - Режим доступа: http://www.natm.ru/triz/articles/shrag005.htm

181. Щеглова, Е.M. Развитие поликультурной компетентности будущих специалистов (На примере курсантов академии МВД): автореф.дис. ... канд. пед. наук / Е.М.Щеглова. - Омск, 2005.

182. Щуркова Н.Е. Программа воспитания школьника / Н.Е.Щуркова. - M., 1998.

183. Якобсон, П.М. Общение людей как социально-психологическая проблема / П.М. Якобсон. - М., 1973.

184. Ястребцева, Е.Н. Как рождается проект: из опыта внедрения методических и организационно-педагогических новвоведений / Е.Н Ястребова. - М., 1995.

185. Boos-Nonning, U., Hohmann, M., Reich, H., Aufnahmeunterricht, Muttersprachlicher Unterricht, Interkultureller Unterricht. Ergebnisse einer vergleichenden Untersuchung zum Unterricht für ausländische Kinder in Belgien, England, Frankreich und den Niederlanden. München 1983.

186. Bourdieu, P., Die feinen Unterschiede. Kritik der gesellschaftlichen Urteilskraft. Frankfurt a.M. 1982

187. Gaitanides, St., Interkulturelles Lernen in einer multikulturellen Gesellschaft. In: Informationsdienst z. Ausländerarbeit, 1994, H. 2, S. 24.

188. Göpfert, H., Ausländerfeindlichkeit durch Unterricht. Konzeptionen und Alternativen for Geschichte, Sozialkunde und Religion. Dısseldorf 1985. 
189. Hackl, B., Miteinander lernen: Interkulturelle Unterrichtsprojekte in der Schulpraxis. Innsbruck 1993.

190. Memmi, A., Rassismus. Frankfurt a.M. 1987.

191. Parsons T. and others. Family, Socialization and Integration Process. Chicago, Free Press, 1955

192. Pommerin, G., Migrantenliteratur und ihre Bedeutung für die interkulturelle Erziehung. In: Zielsprache Deutsch, H. 3, S. 41.

193. Sandfuchs, U., Lehren und Lernen mit Ausländerkindern. Bad Heilbrunn. 1986.

194. Schmidt, U., Interkulturelle Kommunikation und interkulturelles Lernen. In: Jahrbuch «Pädagogik: Dritte Welt”. Kulturelle Identität und Universalität. Frankfurt a.M. 1987. 